Portland State University

PDXScholar

Winter 2-27-2015

\title{
Paleological and Ecological Impacts of Virus Silicification
}

James Robert Laidler

Portland State University

Follow this and additional works at: https://pdxscholar.library.pdx.edu/open_access_etds

Part of the Life Sciences Commons, and the Viruses Commons Let us know how access to this document benefits you.

\section{Recommended Citation}

Laidler, James Robert, "Paleological and Ecological Impacts of Virus Silicification" (2015). Dissertations and Theses. Paper 2194.

https://doi.org/10.15760/etd.2191

This Dissertation is brought to you for free and open access. It has been accepted for inclusion in Dissertations and Theses by an authorized administrator of PDXScholar. Please contact us if we can make this document more accessible: pdxscholar@pdx.edu. 
Paleological and Ecological Impacts of Virus Silicification

\author{
by \\ James Robert Laidler \\ requirements for the degree of \\ Doctor of Philosophy \\ in \\ Biology \\ Dissertation Committee: \\ Kenneth Stedman, Chair \\ Michael Bartlett \\ Sherry Cady \\ Dirk Iwata-Reuyl \\ Todd Rosenstiel
}

A dissertation submitted in partial fulfillment of the

Portland State University

2015 


\begin{abstract}
Silicification of organisms in silica-depositing environments can impact both their ecology and their presence in the fossil record. Although microbes have been silicified under laboratory and environmental conditions, viruses had not been, prior to this work. Bacteriophage T4 was successfully silicified under laboratory conditions that closely simulated those found in silica-depositing hot springs. Virus morphology was maintained during the short period of silicification (48 hours), and a clear elemental signature of silicon and phosphorus was detected by energy-dispersive X-ray spectrophotometry (EDX). However, the EDX signature of silicified virus was not sufficiently distinct from that of cell membrane or phosphate minerals for that technique to be used to discover viral remains in hot spring mineral deposits.
\end{abstract}

Having shown that bacteriophage T4 can be silicified, it was then determined that the impact of silica exposure on infectivity varied widely between different viruses. The effect on infectivity did not appear to be related to virus size or morphology. In addition, the impact on infectivity was at least partially reversible, indicating that it was caused, at least in part, by occluding infection-related structures on the virus, rather than destruction or denaturation of the virus.

Those viruses which showed a decline in infectivity with silica exposure also showed increased resistance to desiccation after being exposed to silica, which has implication for 
long-range virus dispersal. The desiccation resistance was proportional to the degree that silicification reduced infectivity in that virus. Desiccation resistance also declined with prolonged exposure to drying, suggesting that the mechanism was due to the silica coating helping to retain water rather than replacing the hydrogen bonding of water.

Virus dispersal is critical for both the spread of disease and the diverse roles that viruses play in Earth ecology. However, the mechanisms of host-independent virus dispersal are poorly understood and hotly debated. These experiments showed that, under mild conditions, diverse viruses can be coated in silica and that silica coating provides some, if not most, viruses with remarkable desiccation tolerance. Virus silicification thus provides a potential mechanism for global dispersal of viruses that could not otherwise tolerate the desiccation of wind-borne transportation. 


\section{Acknowledgments:}

This research was funded in part by:

NSF-IGERT Fellowship

NASA Astrobiology Institute's Director's Discretionary Fund (grant number

NNA11AC01G)

NASA (Grant NNX07AJ26G and NNX07AT63A. Subaward G258-08-W1951)

NSF (Grant MCB0702020)

I would also like to acknowledge the invaluable assistance and tireless encouragement of my dissertation committee as well as:

Keith Bahjat (Robert W. Franz Cancer Research Center, Earle A. Chiles Research Institute, Providence Cancer Center, Portland, Oregon), who provided advice and laboratory facilities for the work with Vaccinia.

Jessica Shugart (Robert W. Franz Cancer Research Center, Earle A. Chiles Research Institute, Providence Cancer Center, Portland, Oregon), who helped me with the cell culture and plaque assay techniques for Vaccinia. 


\section{Table of Contents}

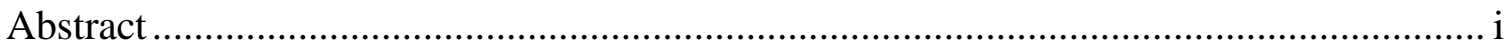

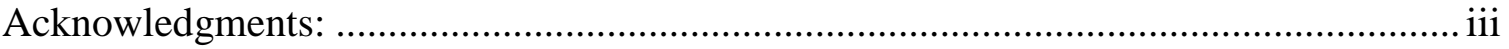

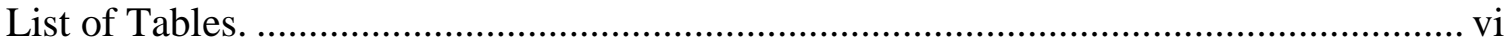

List of Figures. .................................................................................................... vii

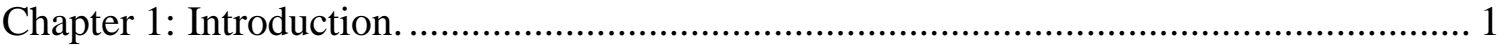

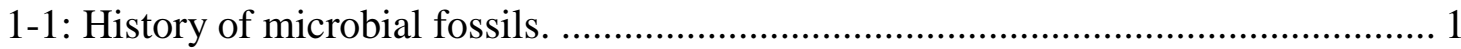

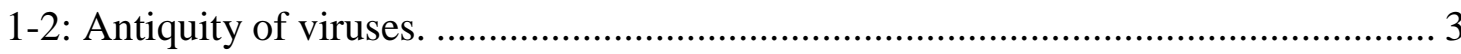

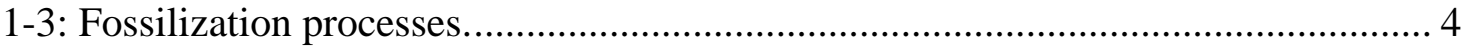

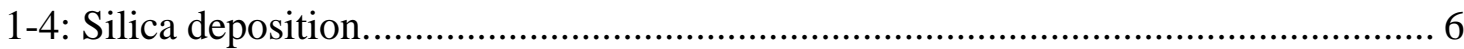

1-5: Homogeneous and heterogeneous nucleation of silica.................................. 8

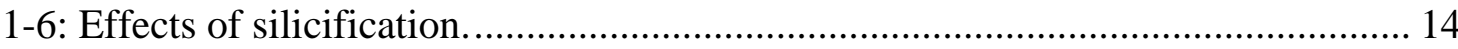

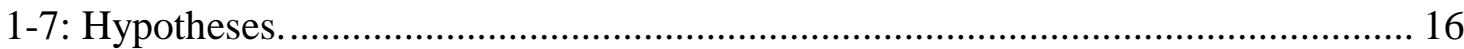

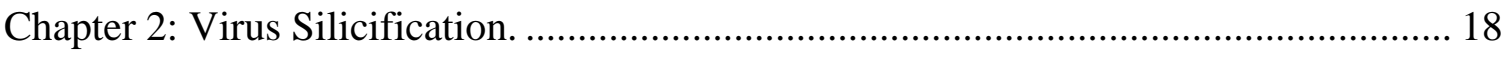

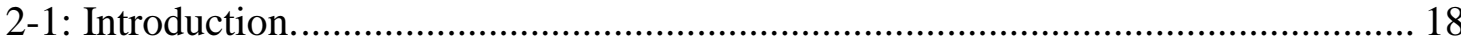

2-2: Silicification Methods.................................................................................... 24

2-3: Environmental sinter collection, preparation and examination. .......................... 28

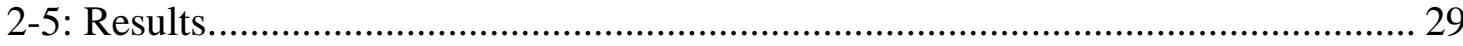

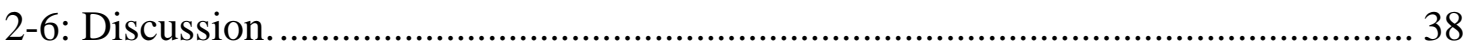

Chapter 3: Effects of Silicification on Virus Infectivity......................................... 45

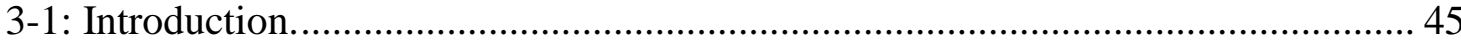

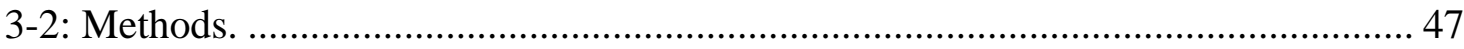

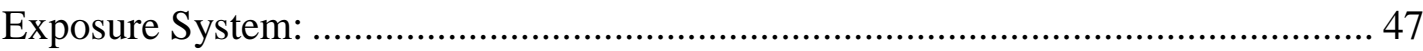

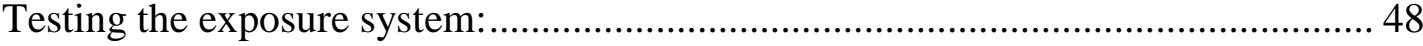

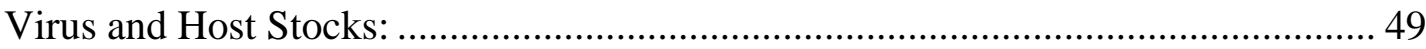

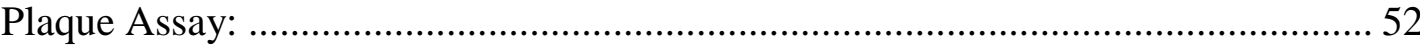

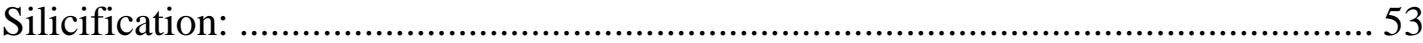

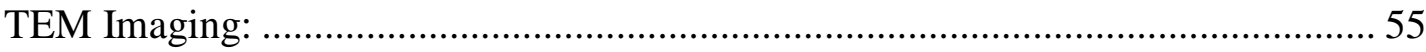

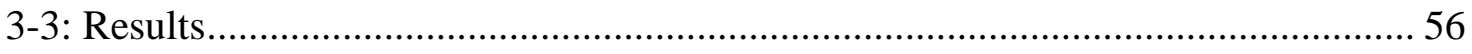




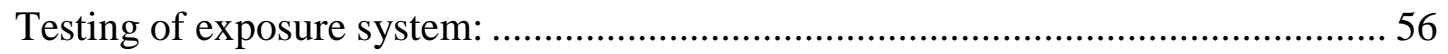

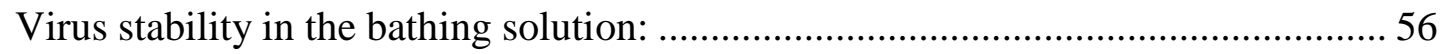

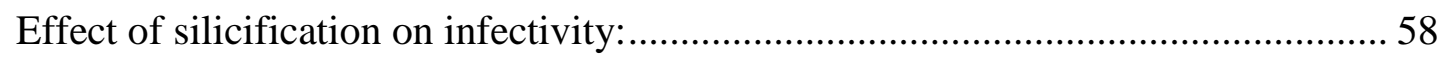

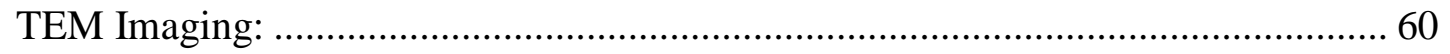

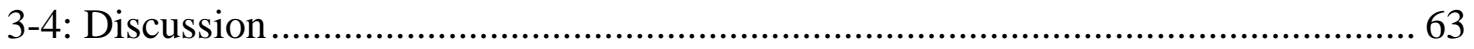

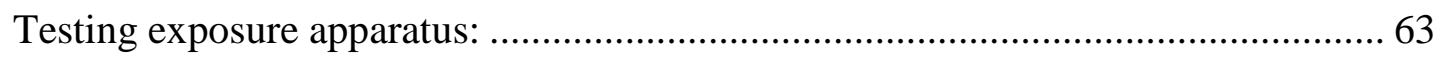

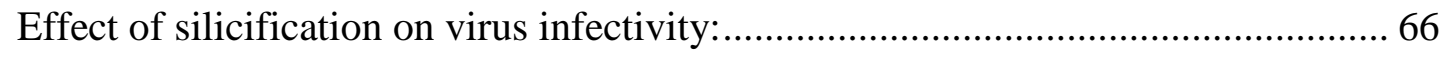

Chapter 4: Effects of silicification on drying tolerance ............................................... 76

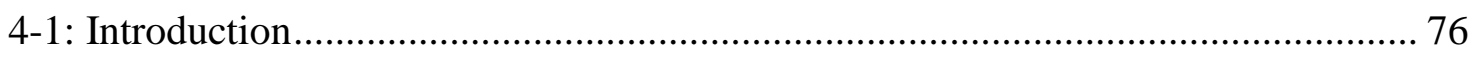

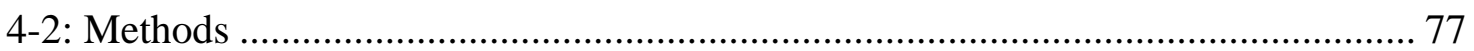

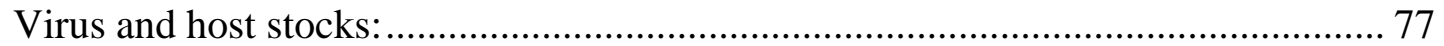

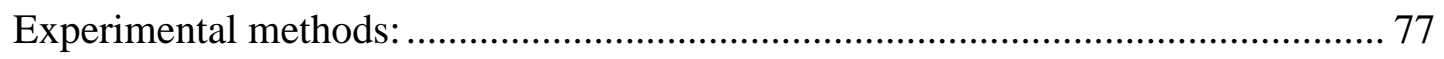

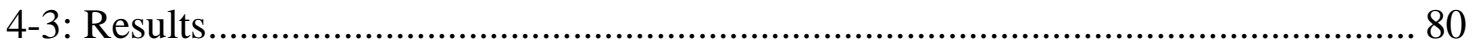

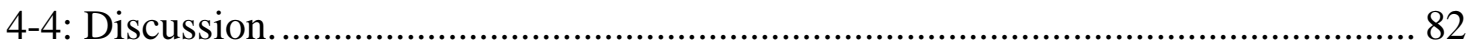

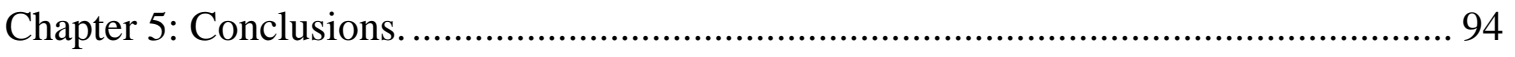

5-1: Viruses can silicify in some environmentally relevant concentrations of dissolved

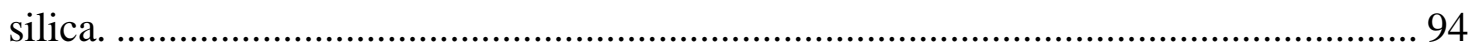

5-2: Silicified viruses will have some recognizable and detectable signature............. 98

5-3: Silicification of viruses will impact their infectivity / Viruses will differ in the degree of silicification or in the impact that silicification has on their infectivity...... 101

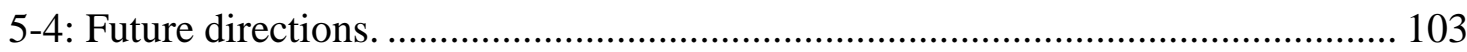

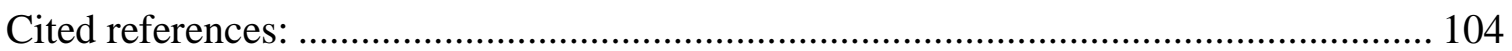




\section{List of Tables.}

Table 2-1. Growler Hot Spring temperature, $\mathrm{pH}$ and selected solutes. ......................... 24

Table 4-1. Selected data from atmospheric sounding. ............................................. 85 


\section{List of Figures.}

Figure 1-1. Illustration of critical radius and its relationship to interfacial energy and volume energy. 10

Figure 1-2. Variation of critical radius $\left(\mathrm{r}_{\mathrm{c}}\right)$ and $\Delta \mathrm{G}$ with concentration. ...................... 11

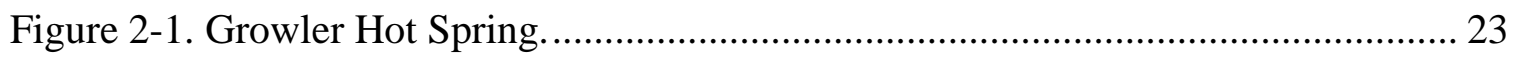

Figure 2-2. Mickey Hot Springs. ........................................................................... 24

Figure 2-3. Silica monomer concentration at different $\mathrm{pH}$ and silica concentrations. ..... 31

Figure 2-4. Bacteriophage T4 exposed to $300 \mathrm{ppm}$ silica without dialyzing. .................. 33

Figure 2-5. TEM images of control and silicified virus............................................... 34

Figure 2-6. Bacteriophage T-4 exposed to $300 \mathrm{ppm}$ silica solution for 72 hours............. 35

Figure 2-7. Bacteriophage T-4 exposed to $300 \mathrm{ppm}$ silica solution for 120 hours........... 36

Figure 2-8. Images of untreated water from Growler Hot Spring. ................................. 36

Figure 2-9. Energy-dispersive x-ray spectroscopy (EDX) of the capsid of a single

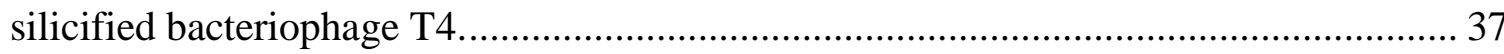

Figure 2-10. Fluorescence microscope image of Mickey Hot Spring sinter. .................. 39

Figure 2-11. Fluorescence microscope image of Growler Hot Spring sinter. ................. 40

Figure 2-12. Fluorescence microscope images of artificial sinter preparations. ............... 41

Figure 3-1. Dialysis apparatus used in infectivity experiments..................................... 49

Figure 3-2. Effect of silicification on infectivity. ....................................................... 59

Figure 3-3. Bacteriophage T-4 virions exposed to solutions containing different

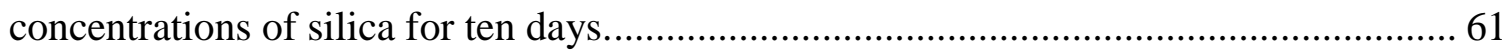

Figure 3-4. SSV-K exposed to solutions containing different concentrations of silica for ten days.

Figure 3-5. Bacteriophage PRD1 virions exposed to solutions containing different concentrations of silica for ten days. 63

Figure 3-6. Bacteriophage T-4 exposed to $600 \mathrm{ppm}$ silica solution for ten days followed by $0 \mathrm{ppm}$ silica solution for an additional ten days.

Figure 3-7. Bacteriophage T-4 exposed to $600 \mathrm{ppm}$ silica solution for ten days followed by $0 \mathrm{ppm}$ silica solution for an additional ten days.

Figure 3-8. Dehydration reactions between silica monomer and various functional groups commonly found on the surface of viruses. 70

Figure 3-9. Illustrating how a divalent metal cation (Me) can act as a bridge between a

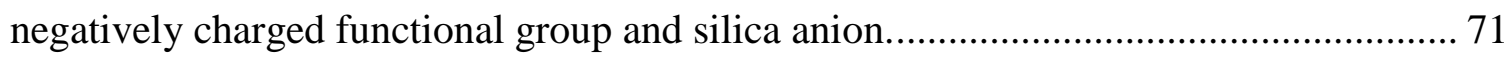

Figure 4-1. Retention of bacteriophage T4 infectivity after drying................................ 81

Figure 4-2. Effect of silicification on ressitance to drying. .......................................... 83 


\section{Chapter 1: Introduction.}

\section{1-1: History of microbial fossils.}

Many hypotheses about the origin of viruses conclude that they are extremely ancient, emerging at roughly the same time as cellular life if not shortly before or after (Forterre, 2006a; Koonin et al., 2006). Opposing the hypotheses of an ancient viral origin are a number of hypotheses proposing that viruses arose relative recently from cellular organisms (e.g. Agol, 2010). There are numerous findings of microbial fossils - Bacteria and/or Archaea - that date back to over 3 billion years ago (Brocks et al., 2003; Brocks et al., 1999; Schopf and Packer, 1987). If viruses evolved at or near the same time as cellular life, we should expect to find viruses fossilized along with their microbial hosts, assuming that the viruses can be fossilized. The presence of viruses in the fossil record does not, of course, mean they can be found today. Detecting fossil viruses requires not only that they be embedded into the forming rock, but also that they are somehow preserved in a form that can be unambiguously identified as virus. That is one of the goals of my dissertation research.

In 1915, Charles Walcott published the first report of fossilized bacteria (Walcott, 1915), which he had discovered in Algonkian (now called Late Proterozoic) limestone of the Newland formation of Western Montana, a formation between 1.3 and 0.9 billion years old (Hall and Veizer, 1996). Based on their morphology as seen in petrographic thin section, he tentatively identified them as micrococci, but the only definitive identification 
possible is that they were sub-micron spherical objects. The technology of the time limited the analyses possible and there is no indication that the specimens described by Walcott have been re-examined with more modern techniques.

Fifty years after the publication of Walcott's discovery, within months of each other, two articles were published in Science describing fossilized bacteria found in the Gunflint chert, a banded iron formation in the Gunflint range of Northern Minnesota and Ontario (Barghoorn and Tyler, 1965; Cloud, 1965). This formation has been dated to 2.0 billion years ago. The same year, a brief report of fossil bacteria in pyrite was also published (Ehlers et al., 1965). More recent discoveries have provided fossil evidence of cellular microbial life as far back as 3.8 billion years ago (Al-Hanbali and Holm, 2002; Altermann and Schopf, 1995; Schopf, 2006; Schopf and Packer, 1987; Tice and Lowe, 2004).

There is some controversy about these microbial fossils, especially the oldest. After billions of years exposure to heat, pressure and the crystallization of the minerals surrounding them (Jones and Renaut, 2007; Lynne and Campbell, 2003; Lynne and Campbell, 2004), there is usually little of the original organism remaining (Moreau and Sharp, 2004), apart from its morphology. As some researchers have pointed out, there are abiological processes that can create similar shapes in minerals (Brasier et al., 2005; Garcia-Ruiz et al., 2003; Lowe, 1994), which could call into question the validity of some of the older findings. Despite the controversy, there appears to be broad consensus the 
fossil record directly supports the existence of cellular microbes - similar if not identical to current bacteria - dating back to at least 3.6 billion years ago.

Microbial fossils have been found in a variety of minerals, including limestone (Walcott, 1915) and phosphorites (Álvaro and Clausen, 2010), but the most common substrate for microbial fossils are cherts. This may be due, in part, to the microcrystalline or cryptocrystalline nature of cherts that helps preserve the structure of the embedded fossils. In addition, cherts can form at low (in the geological sense) temperatures and are resistant to weathering and metamorphism, which also preserve the structure of the embedded fossils.

\section{1-2: Antiquity of viruses.}

Unlike the evidence that has accumulated supporting the antiquity of cellular microbes, there is almost no direct evidence of the antiquity of viruses. The current best evidence that viruses existed prior to the Holocene epoch (the current geological epoch, which began 11,700 years ago) is the presence of cellular inclusion bodies - similar to those caused by modern polyhedrosis viruses - seen in insects preserved in Early Cretaceous amber (Poinar and Poinar, 2005). Despite this lack of direct evidence, there is considerable indirect evidence, such as the presence of endogenous retroviruses and other "molecular fossils" in the genomes of current organisms (Feschotte and Gilbert, 2012;

Theze et al., 2011). These data suggest that viruses have been in existence for at least 300 million years (Theze et al., 2011) and probably even longer. 
Considering how much controversy has surrounded bacterial fossils, particularly the oldest ones (Brasier et al., 2005; Garcia-Ruiz et al., 2003; Lowe, 1994), putative virus fossils would naturally be met with skepticism. To begin with, virus fossils would be ten times smaller in length than bacterial fossils - one thousand times smaller in volume. Additionally, it would be important - and difficult - to discriminate between virus fossils and small fossilized cell fragments. Finding virus-specific markers that can survive diagenesis will be critical in the unambiguous identification of virus fossils.

Currently, most, if not all, environments that contain microbes also have viruses, usually in numbers that exceed those of the accompanying microbes by an order of magnitude or greater (e.g. de Araujo and Godinho, 2009; Filippini et al., 2008; He et al., 2009; Helton et al., 2012; Magagnini et al., 2007; Maranger and Bird, 1995; Peduzzi and Schiemer, 2004; Personnic et al., 2009; Slovackova and Marsalek, 2008; Swanson et al., 2009). Assuming that this modern relationship was seen in the Proterozoic ( 2.5 billion to 541 million years ago) and Archaean ( 4 billion to 2.5 billion years ago) eons as well, there is the possibility that viruses were fossilized along with their microbial hosts, so any rock that holds microbial fossils could contain viral fossils as well. Of course, this also presumes that viruses are capable of being fossilized, an issue very much in question.

\section{1-3: Fossilization processes.}

Whether viruses can be incorporated in the fossil record in any form, detectable or not, is the critical question. This is not mere sophistry, but a serious consideration. There are 
three major factors that could impact whether or not viruses can be fossilized: first, can viruses become incorporated in rock, or would they be excluded from the forming solid phase? There may be many different answers to this first question, depending on the type of mineral being formed. Secondly, would the process of mineral formation destroy the virus? Finally, if the virus were to be incorporated intact into the solid mineral phase, would its constituents remain localized or would they diffuse into the surrounding mineral? Again, this answer would likely vary depending on the particular mineral being considered.

In the case of fossilization in silicate minerals, such as cherts, the first step in the fossilization would be coating the virus in silica, a process that has been observed in detail with bacteria and archaea (Amores and Warren, 2007; Asada and Tazaki, 2001; Benning et al., 2004a; Benning et al., 2004b; Furukawa and O'Reilly, 2007; Orange et al., 2009; Peng et al., 2007; Phoenix et al., 2000; Renaut et al., 1998; SchultzeLam et al., 1995; Toporski et al., 2002; Westall et al., 1995). If viruses follow the same process, they would be coated with a layer of amorphous silica; after that, the coated viruses would become enmeshed in a silica sinter. Over time, the interstitial spaces of the sinter would become occluded with more amorphous silica, forming a solid mass of hydrated amorphous silica (Cady and Farmer, 1996). At this point, the solid sinter would be largely composed of opal A, amorphous hydrated silica formed at geologically low temperatures and pressures. Over time, even without burial, the opal A would gradually transition to microcrystalline opal CT or opal C and, eventually, to microcrystalline quartz (Herdianita et al., 2000; Hesse, 1989; Lynne et al., 2005). During this process of 
diagenesis, the crystallization and re-crystallization tends to disrupt the structure of any embedded organisms (Cady and Farmer, 1996; Jones et al., 2004b). The presence of recognizable microbial fossils in cherts indicates that the morphological disruption is not always sufficient to eradicate all trace of the embedded microbes, but viruses are an order of magnitude smaller than bacteria and archaea and would likely suffer a correspondingly more severe degree of disruption. Even if viruses can be coated with silica and enmeshed within silica sinter, the subsequent crystallization and re-crystallization of diagenesis could render any viral remnants unrecognizable. However, there is the possibility that some biosignature could remain that was sufficiently specific to viruses to allow a presumption that virus remains were encased within the rock. This approach has been successful in detecting microbial remains in substrates as amorphous as shale oil (Bechtel et al, 2012).

\section{1-4: Silica deposition.}

Before virus remnants can be identified in the fossil record, they have to get there, which brings the focus back to the question of whether viruses can become encased in silica in the first place. While it might seem intuitive that, since bacteria can become silicified in silica-depositing hot springs, viruses should as well, there are experimental data that suggest this might not be as straightforward as it seems. The chemistry of silica is quite complex and a variety of factors control its deposition out of solution. 
The first and possibly most obvious factor is the concentration of silica in the solution. In most natural hot spring waters, the concentration of silica is controlled to a large extent by the temperature of the reservoir or the source of the hot spring (Guidry and Chafetz, 2003; Iler, 1979b; White et al., 1956). This relationship between silica concentration and water temperature is robust enough that silica concentration has been used as a surrogate measure for the temperature of deep reservoirs (Verma, 2000; White et al., 1956). There are limitations to the fidelity of this relationship; the water in the deep reservoir has to be in contact with silicate minerals (such as quartz) and the contact time must be long enough for the dissolution of silica to reach equilibrium. Also, the transit of water from the deep reservoir to the surface (or point of sampling) must be rapid enough that there is no significant loss of silica due to deposition along the way. Nonetheless, the silica concentration in hot spring waters is largely determined by the temperature of the water at depth. The exceptions to this principle are those hot springs that are steam-fed rather than being connected to the deep hot water reservoir. In these springs, the water is meteoric water that is heated by steam and other hot gases rising up through the bottom of the spring; the water has not been in contact with silicate rocks at high temperature, so its silica concentration can be no more than the equilibrium concentration at the spring temperature. Although the deep reservoir in these steam-dominated systems is much hotter than that of the surface spring, the silica concentration will not reflect that. Water in prolonged contact with quartz or other silica-containing minerals will eventually become saturated with silica. If this water is then cooled or allowed to evaporate, the solution will become first oversaturated and, if the process continues, supersaturated. "Oversaturated" and "supersaturated" in this context mean very specific regimes of 
concentration, as opposed to the common usage, where they are often seen as synonymous. "Oversaturated" indicates concentrations that exceed equilibrium concentration ("saturated") but are less than the concentration where homogeneous nucleation occurs. "Supersaturated" indicates concentrations at or above the concentration necessary for homogeneous nucleation.

As the hot spring water travels to the surface, it begins to cool from conductive heat losses to cooler rock in the ascent channel. If the water was at or near saturation before cooling, it will become oversaturated as it cools. Once the water is oversaturated, the silica will begin to deposit on solid material in contact with the water. However, the kinetics of this reaction are slow enough that the dissolved silica will often become even more oversaturated as the water cools further on its ascent (Icopini et al., 2005; Weres et al., 1981). Once the water reaches the surface, it will cool further from radiative and evaporative heat losses as well as conduction, further increasing the degree of oversaturation. Evaporation will also increase the absolute concentration of silica. The combination of these processes will often result in hot spring water that is oversaturated, if not supersaturated, in silica for its temperature and composition.

\section{1-5: Homogeneous and heterogeneous nucleation of silica.}

In the concentration regime of oversaturation, silica will precipitate onto solid surfaces and on particles above a certain radius. If the silica concentration reaches supersaturation, homogenous nucleation - spontaneous precipitation of silica out of solution without a 
“seed" particle or surface - may occur. Homogeneous nucleation occurs only at concentrations significantly higher than the saturation concentration because of radius effects; although the precipitation of silica out of solution (at concentrations above saturation) is energetically favorable (negative $\Delta \mathrm{G}$ ), the initial molecules that precipitate are surrounded by solute and the interfacial energy, which favors dissolution (positive $\Delta \mathrm{G}$ for precipitation), opposes precipitation. In the initial stages of precipitation, the volume energy of precipitation ( $\Delta \mathrm{G}_{\mathrm{v}}$, the energy of precipitation expressed in terms of volume), which increases with the cube of the radius, is overwhelmed by the interfacial energy, which increases with the square of the radius, as shown below in the equation for the Gibbs free energy of deposition. Thus, adding molecules to very small particles is an endothermic process, with the $\Delta \mathrm{G}$ becoming more positive until the particle reaches a critical radius, $r_{c}$, the equation for which is shown below, at which point the $\Delta \mathrm{G}$ reverses its trend and becomes more negative as the volume energy becomes dominant (Figure 11) (Alexander, 1957; Chan, 1989; Hidalgo and Orr, 1968; Iler, 1979b).

$$
\Delta G=4 \pi r^{2} \sigma+\frac{4 \pi r^{3} \Delta G_{v}}{3}
$$

Gibbs free energy of deposition. $\sigma$ is interfacial free energy, $\Delta G_{v}$ is the Gibbs free energy of crystallization per unit volume.

With increasing solute concentration, the volume energy term becomes increasingly dominant, which reduces both the critical radius and the positive deflection of $\Delta \mathrm{G}$ at the 
critical radius (Figure 1-2). This positive $\Delta \mathrm{G}$ at low particle radius acts in many ways like activation energy in that it forms a stochastic barrier to particle growth. At lower solute concentrations, there is a lower probability that a particle can grow to the point where the $\Delta \mathrm{G}$ of further growth is energetically favorable. This leads to not only a greater number of particles forming at higher solute concentrations but also faster growth of the particles that form, since the energy barrier is lower and particle growth becomes energetically favorable at a smaller particle radius. Once particles have grown to the point where the

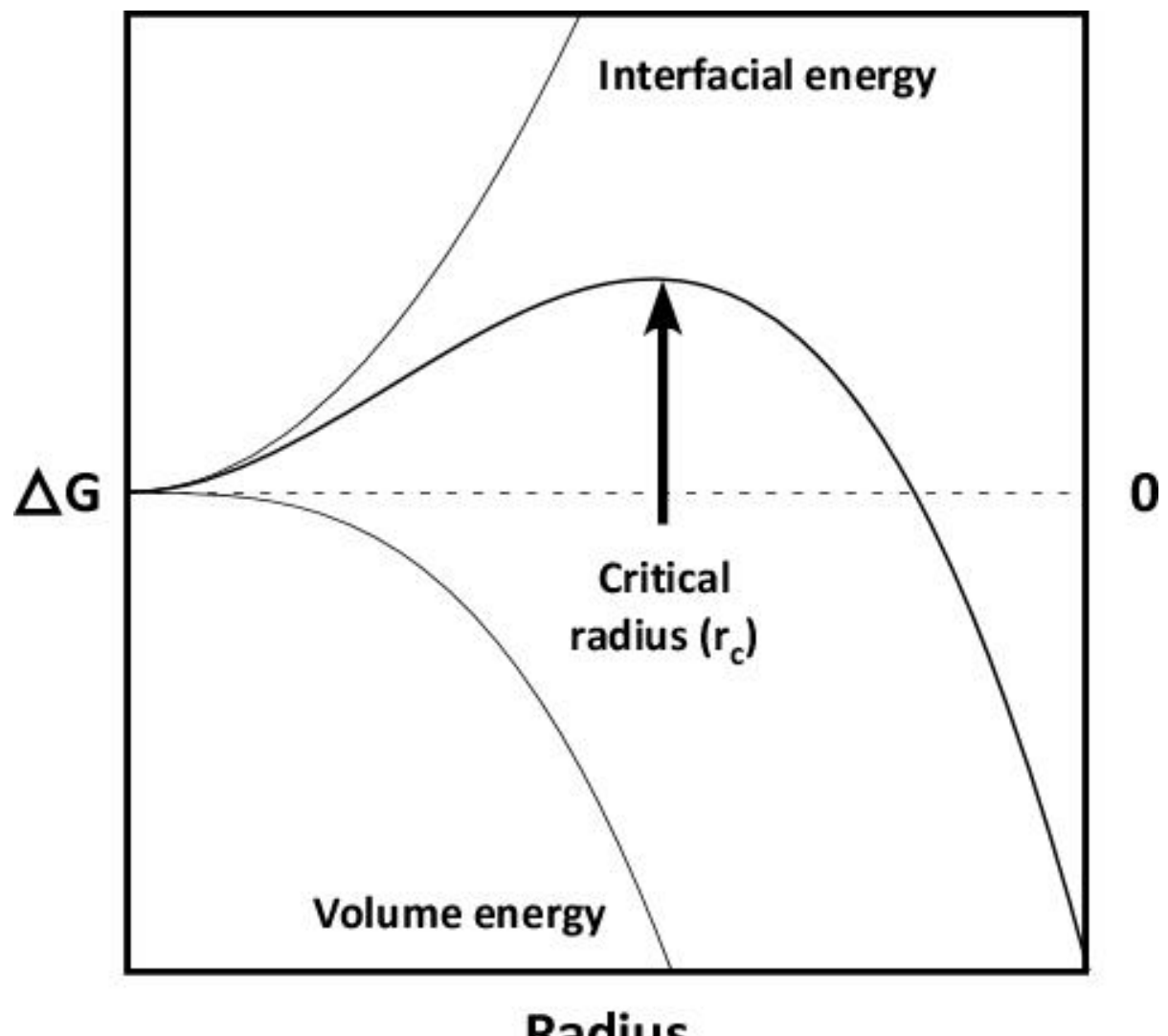

Figure 1-1. Illustration of critical radius and its relationship to interfacial energy and volume energy. At the critical radius $(\mathrm{rc}), \delta G / \delta \mathrm{r}$ changes from positive to negative; the radius at which deposition on the growing particle is exergonic is greater than rc. 


$$
r_{c}=-\frac{2 \sigma}{\Delta G_{v}}
$$

Critical radius $\left(r_{c}\right) . \sigma$ is interfacial free energy, $\Delta G v$ is the Gibbs free energy of crystallization per unit volume.

$\Delta \mathrm{G}$ is negative, they can act as nuclei for further deposition, growing at the expense of smaller particles, a process known as Ostwald ripening (Iler, 1979b).

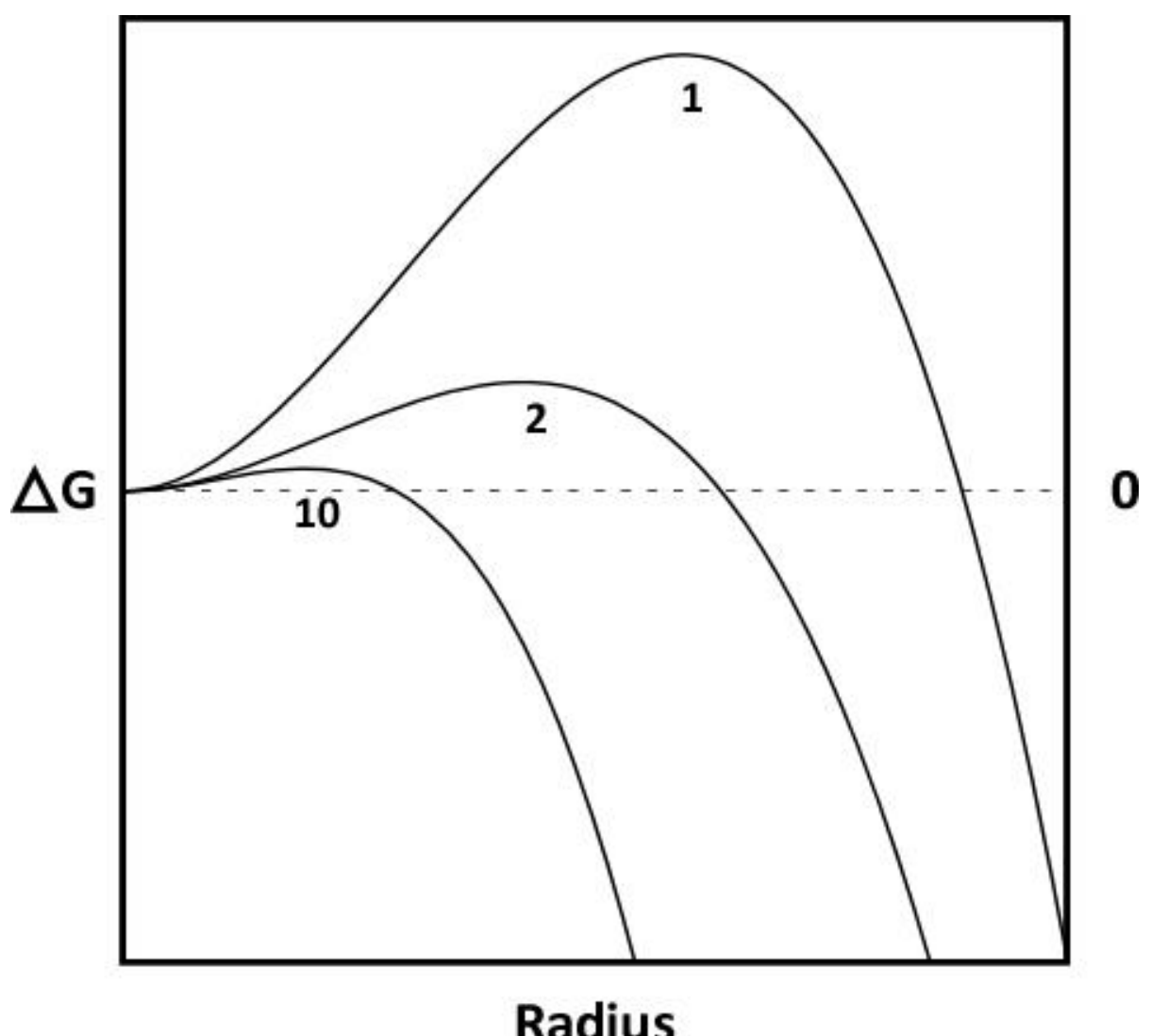

Figure 1-2. Variation of critical radius $\left(r_{c}\right)$ and $\Delta G$ with concentration. Curves are for solute concentrations 1,2 and 10 times a nominal value. 
These factors combine to delineate the regimes of oversaturation and supersaturation, although the boundary is not sharp, the result of the stochastic nature of particle formation, which leads to "fuzzy" boundaries. However, it is possible to define, if somewhat arbitrarily, a point at which the rate of homogeneous nucleation is so low that it is not a significant contributor to the behavior of the system. For silica solutions, that concentration is generally agreed to be $2-2^{1 / 2}$ times the equilibrium concentration (Klein, 1995).

Below this somewhat arbitrary point of supersaturation, silica precipitates primarily on pre-existing particles, a process known as heterogeneous nucleation. The heterogeneous nuclei, such as dust particles, microbes or - potentially - viruses, provide a surface with a radius sufficiently greater than $r_{c}$ such that silica precipitation is energetically favorable or can at least proceed at a significant rate. Silicification of microbes has been show to occur - both in the laboratory and in nature - at concentrations below supersaturation (Benning et al., 2004b; Phoenix et al., 2000; Renaut et al., 1998), presumably by heterogeneous nucleation. However, viruses are significantly smaller, much closer to the critical radius than bacteria or other microbes.

Depending on silica concentration and temperature, the critical radius is on the order of a few nanometers to several tens of nanometers (Chan, 1989; Conrad et al., 2007; Iler, 1979a; Weres et al., 1981); at lower silica concentrations, the critical radius could approach that of viruses $(50-100 \mathrm{~nm})$, making them too small to act as effective heterogeneous nuclei. Even at dissolved silica concentrations significantly above 
saturation (but below supersaturation), the deposition of silica on viruses may be endergonic (Figure 1-1) and thus proceed slowly, if at all. If this is the case, there would be several consequences; among these would be that viruses could not be incorporated into the fossil record, at least not in silicate rocks, because they would remain in the fluid phase during silica deposition and be lost.

Because the deposition of silica on small particles depends on several factors, calculation of the critical radius alone cannot be used to definitively determine whether or not viruses can act as heterogenous nuclei. It has been well documented in bacteria that surface features, such as the exposed functional groups of proteins, polysaccharides and lipid membranes can interact chemically with silica and influence its deposition on their surface (Cox et al., 1999; Doyle et al., 1980; Fein et al., 1997; Wei et al., 2004). Many of these same surface features exist on viruses and could similarly influence the deposition of silica. Other factors include the presence of other metallic ions in the solution, such as aluminum (Yokoyama et al., 2004), sodium, calcium and magnesium (Chen and Marshall, 1982; Dove and Nix, 1997; Tanaka and Takahashi, 2002). With viruses being near the critical radius in many of the environments where microbial silicification occurs, there is some doubt about whether they will silicify in nature. What is needed, then, is to experimentally determine if they can silicify in the laboratory and under what conditions. 


\section{1-6: Effects of silicification.}

Fossilization is not the only potential effect of virus silicification; research into microbial silicification have shown that it can have significant effects on microbial survival (Asada and Tazaki, 2001; Benning et al., 2004a; Geptner et al., 2005; Jones et al., 2004a; Peng et al., 2007; Renaut et al., 1998) and it is logical to assume similar effects would be seen if viruses were silicified. Given the unique metabolic aspects of viruses - specifically, that they do not have detectable metabolism outside of their host - silicification would not necessarily "kill" or irreversibly inactivate a virus in the same way it has been shown to kill cellular organisms. However, since a virus' ability to infect a host cell depends on surface features - the interaction between viral surface proteins and "receptors" on the host cell surface - a sufficiently thick layer of silica deposited on the surface of a virus should render it incapable of infecting a host cell by simple mechanical interference with the virus-cell interaction.

There are several potential consequences of virus inactivation by silica. First, and most obvious, is the impact it would have on viral infection in silica-depositing environments. Many of these silica-depositing environments are hydrothermal systems and viruses may be an important microbial predator, possibly the only one (Breitbart et al., 2004b;

Ortmann and Suttle, 2005; Weinbauer, 2004). In these environments, cellular organisms use biofilms and other metabolically active strategies to evade lethal silica envelopment (Doi et al., 2009; Peng et al., 2007); extra-cellular viruses, on the other hand, are unable to employ strategies requiring metabolism because they are unable to metabolize. 
The potential of virus inactivation by silicification in silica-depositing environments would apply a selection pressure on viruses favoring mutations that reduce the risk of inactivation. There are two broad categories of mutations that could affect this change: the first are alterations in the viral surface (capsid or envelope) that are less favorable to silica deposition. Several studies have shown that certain amino acids and peptide structures are more favorable to silica deposition than the "average" and some are less favorable (Coradin et al., 2002; Coradin and Livage, 2001; Dickerson et al., 2008; Fang et al., 2008; Liang et al., 2009; Naik et al., 2002; Patwardhan et al., 2006). Their data strongly suggest that it would be possible for viruses to evolve surfaces that can slow or even stop the deposition of silica at environmental concentrations.

The second broad category of silicification avoidance strategies are virus replication cycles that limit or avoid exposure to silica. Temperate phage, which replicate along with their host as either an episome or integrated into the host genome (Hendrix and Casjens, 2006), are able to utilize their hosts' silica evasion responses to their own advantage, while retaining the ability to infect other host cells in the same environment [see Golais et al., 2012 for a review of lysogeny]. Some viruses, such as the Fuselloviridae infecting Sulfolobus and related archaeal genera, appear able to simultaneously retain an integrated copy and produce infectious virus particles without lysing the host cell (Contursi et al., 2006; Schleper et al., 1992; Wiedenheft et al., 2004; Zillig et al., 1996) [see Prangishvili, 2013 for a review of archaeal viruses]. This allows them to maintain a "backup" copy protected from the environment while seeding the local area with infectious virus particles to infect any uninfected host cells that might be present. 
Another possible consequence of virus inactivation by silica deposition would be a reduction in viral-mediated microbial predation, as alluded to above. This would be especially apparent in those environments - such as hot springs - where viruses are the dominant microbial predator (Jardillier et al., 2005; Ortmann and Suttle, 2005;

Weinbauer, 2004). A loss of viral predation in these environments could potentially cause a reduction in microbial diversity, especially the variation over time. Viruses, because of their relatively narrow host range, have a much more selective effect on microbial populations than Eukaryotic microbial predators, which often leads to a disproportionate effect on the "dominate" microbial species. This is often referred to as the "kill the winner" effect (Fuhrman and Schwalbach, 2003; Thingstad, 2000). There is a paucity of studies examining microbial diversity over time in any environment, but there is one study that investigated microbial diversity over time in hot springs of different silica concentrations (Snyder, 2005). In the data from that study, it appears that hot springs with lower silica concentrations experience a greater turnover in microbial diversity. However, there are other, potentially more significant differences between the hot springs examined, such as age of the hot spring and water chemistry.

\section{1-7: Hypotheses.}

In a series of studies, I demonstrated that viruses can be silicified under environmentally relevant conditions. Then, I elucidated the effects of silicification and desilicification on the infectivity of a variety of viruses. Finally, I showed that silicification can provide 
viruses some degree of protection from desiccation and potentially allow them be propagated over long distances.

The experiments were based on the following falsifiable hypotheses:

1. Viruses will become coated with silica - will silicify - on exposure to environmentally relevant concentrations of dissolved silica.

2. There will be a detectable and unique signature remaining after the viruses are coated with silica.

3. Coating viruses with silica will reduce their infectivity.

4. Different viruses will silicify to differing degrees, a reflection of variable surface characteristics, as manifested by differing impacts on infectivity. 


\section{Chapter 2: Virus Silicification.}

(adapted from Laidler and Stedman, 2010)

\section{2-1: Introduction.}

Viruses are the most abundant microorganisms on the planet; an estimated $10^{30}$ viruses inhabit the waters of Earth's oceans (Suttle, 2005). Environmental virus concentrations range widely: up to $10^{7}$ per milliliter in hot springs and hydrothermal vents (Breitbart et al., 2004b; Diemer and Stedman, 2012; Lee et al., 2007; Ortmann and Suttle, 2005) to $10^{5}$ to $10^{8}$ per milliliter of seawater (Filippini et al., 2008; He et al., 2009; Suttle, 2005; Wommack and Colwell, 2000), $10^{7}$ to $10^{9}$ per milliliter in freshwater lakes and streams (de Araujo and Godinho, 2009; Personnic et al., 2009; Slovackova and Marsalek, 2008) and up to $10^{9}$ per gram of soil (Swanson et al., 2009). In almost all of these environments, viruses outnumber prokaryotes (bacteria and archaea), often by an order of magnitude or more (Breitbart et al., 2004b; de Araujo and Godinho, 2009; Filippini et al., 2008; He et al., 2009; Lee et al., 2007; Ortmann and Suttle, 2005; Personnic et al., 2009; Slovackova and Marsalek, 2008; Suttle, 2007; Swanson et al., 2009; Wommack and Colwell, 2000). Viruses are thought by many to be ubiquitous companions of all cellular life (Forterre, 2006a; Koonin and Martin, 2005; Koonin et al., 2006). Although there are numerous cellular organisms without known virus "companions," this is thought to be due to the difficulties of finding viruses rather than any inherent lack of viruses in these organisms.

Although generally viewed as parasites, viruses can play other roles in the environment, such as promoting horizontal gene transfer between organisms, including organisms of 
different species (Beumer and Robinson, 2005; Filee et al., 2002; Jiang and Paul, 1998; Kenzaka et al., 2007; Ripp et al., 1994; Sullivan et al., 2006; Weinbauer, 2004). Another important ecological role viruses play is that of microbial predator; in that role, they help recycle scarce nutrients (e.g. nitrogen, iron and phosphorus) (Ortmann and Suttle, 2005; Riemann and Middelboe, 2002; Weinbauer, 2004). Viral predation also increases the species diversity of microbial ecosystems (Hennes and Simon, 1995; Jardillier et al., 2005; Weinbauer, 2004) because the more prevalent microbes are more likely to encounter a virus that can infect them than microbes which are less prevalent and have a lower population density. This "kill the winner" effect (Thingstad, 2000) preferentially reduces the population of the dominant species, increasing diversity. The role as predator is particularly important in ecosystems where the more "typical" eukaryotic microbial predators, such as amoebae, rotifers and nematodes, are unable to function effectively. Such ecosystems include hydrothermal environments where the temperature is persistently above $60^{\circ} \mathrm{C}$, which is thought to be the upper temperature limit for eukaryotic life (Baumgartner et al., 2002; Baumgartner et al., 2003). Many of these hydrothermal waters become oversaturated in silica as they cool to ambient temperature (White et al., 1956). Microorganisms in these silica-depositing waters can act as nucleation sites for silica polymerization, which leads to their being encased in silica (Amores and Warren, 2007; Cady and Farmer, 1996; Jones et al., 2004a; Jones et al., 2000; Konhauser et al., 2004; McKenzie et al., 2001; Peng et al., 2007; Renaut et al., 1998; SchultzeLam et al., 1995) and, after diagenesis, their preservation in the fossil record (Al-Hanbali and Holm, 2002; Cady and Farmer, 1996; Cloud and Licari, 1968; 
Geptner et al., 2005; Reysenbach and Cady, 2001; Schopf, 2006; Schopf and Packer, 1987).

In 1915, Charles Walcott was the first to report finding fossilized microbes: blue-green algae (now called cyanobacteria) in limestone of the Newland Formation in central Montana (Walcott, 1915). Since that time, there have been a number of similar findings in a variety of mineral settings (e.g. Altermann and Schopf, 1995; Barghoorn and Tyler, 1965; Cloud, 1965; Schopf, 2006; Schopf and Packer, 1987). Many of the most distinct microbial fossils are those that have been found in silica-rich rock, for example, cherts and flints. Despite vigorous debate about the oldest of these finds (Brasier et al., 2005; Garcia-Ruiz et al., 2003; Lowe, 1994), the consensus is that these fossils date the beginning of microbial life to earlier than 3 billion years ago. Currently, microbes in hydrothermal springs are often accompanied by, and presumably infected with, a variety of viruses (Breitbart et al., 2004b; Geptner et al., 2005; Lee et al., 2007; Prangishvili 2013; Prangishvili et al., 1999; Reysenbach and Cady, 2001; Snyder, 2005; Stedman et al., 2006). Thus, it is reasonable to assume that these viruses would be silicified along with their microbial hosts in a silica-depositing environment.

If viruses can be silicified along with their hosts, it is also possible that they might be present in the fossil record. Discovery of fossilized viruses would be a boon not only to virologists but also to those interested in the origins of life on Earth and elsewhere. While it is supposed that viruses originated at approximately the same time as cellular life (Forterre, 2006a; Forterre, 2006b; Koonin et al., 2006), there is no direct evidence of 
viruses prior the development of the transmission electron microscope (TEM) in the past century (Stanley and Anderson, 1941). It would, of course, be utter sophistry to assert that viruses which caused such distinctive human diseases as polio and smallpox cannot be assumed to have existed prior to their visualization with the electron microscope in 1941. In addition, there is indirect evidence of ancient viruses, such as the presence of structures that resemble modern polyhedrosis virus inclusions visible in insects trapped in amber dated to 100 million years ago (Poinar and Poinar, 2005). Phylogenetic and structural analysis also supports the ancient nature of viruses (Benson et al., 2004; Filee et al., 2002; Hendrix et al., 1999; Holmes, 2003; Rice et al., 2004).

While virus silicification would be an important step toward their incorporation into the fossil record, it is only the first step. Whether recognizable fossil viruses or detectable biosignatures would survive the process of converting sediment or silica deposits into rock (diagenesis) is currently unknown. The oldest molecular biosignatures, from specimens billions of years old, are remnants of membrane lipids (e.g. Brocks et al., 2003; Brocks et al., 1999). While bacteriophage T4 (used in this study) does not have a lipid envelope (the viral analogue to a cell membrane), many viruses, including some bacteriophage, such as PM2, PRD1, Bam35 and Phi6, do contain lipids and even lipid membranes (Laurinavicius et al., 2007). Proteins (Nielsen-Marsh et al., 2009) and DNA (Haile et al., 2009; Noonan et al., 2006) have also been isolated and sequenced from specimens tens of thousands of years old. Thus, it appears possible that some viral components could survive to be incorporated into fossils. If viral lipids can be 
distinguished from their host membrane lipid, it might be possible to identify a viral biosignature even when virus morphology has been altered beyond recognition.

In this chapter, I describe how bacteriophage T4 was silicified under conditions similar to those observed in the outflow channels of silica-depositing hot springs - room temperature and 300ppm (5mM) silica (McCleskey et al., 2004; Renaut et al., 1998; White et al., 1956). The methods used were similar to those used in the experimental silicification of bacteria (Benning et al., 2004a; Benning et al., 2004b; Konhauser et al., 2004; Orange et al., 2009; Toporski et al., 2002; Westall et al., 1995; Yee et al., 2003). Bacteriophage T4 was used because it has been extensively studied (Karam, 1994); its genome (Miller et al., 2003), structure (Aksyuk et al., 2009; Fokine et al., 2004; Leiman et al., 2004), and host interactions (Filee et al., 2005; Karam, 1994; Kenzaka et al., 2007; Mosig et al., 2001) are well characterized. The silicified viruses have a clearly recognizable morphology and a detectable phosphorus signal on elemental analysis.

I also made attempts to identify viruses in modern silica sinters from two geothermal springs, using a fluorescent nucleic acid stain. Although silicified viruses have not yet been unambiguously identified in the environment, there are indications that they may exist (Peng et al., 2013). I collected subaerial silica sinter from two silica-depositing hot springs in different regions: Growler Hot Spring (“The Growler") and Mickey Hot Springs. Growler Hot Spring is a neutral silica-depositing geothermal spring located outside of the boundaries of Lassen Volcanic National Park but part of the Lassen geothermal complex (Janik and McLaren, 2010). Its chemistry has been studied for 
several decades (Thompson 1985), but there have been no published studies of its microbial ecology. Table 2-1 shows the chemistry of Growler Hot Springs. Water emerges from its surface outlet (Figure 2-1A) at $95^{\circ} \mathrm{C}$, near the boiling point of water at that elevation; there is no visible evidence of microbial community at the outlet (e.g. mats, streamers, etc.) but the outlet channel is lined with a dense microbial mat (Figure 21B).

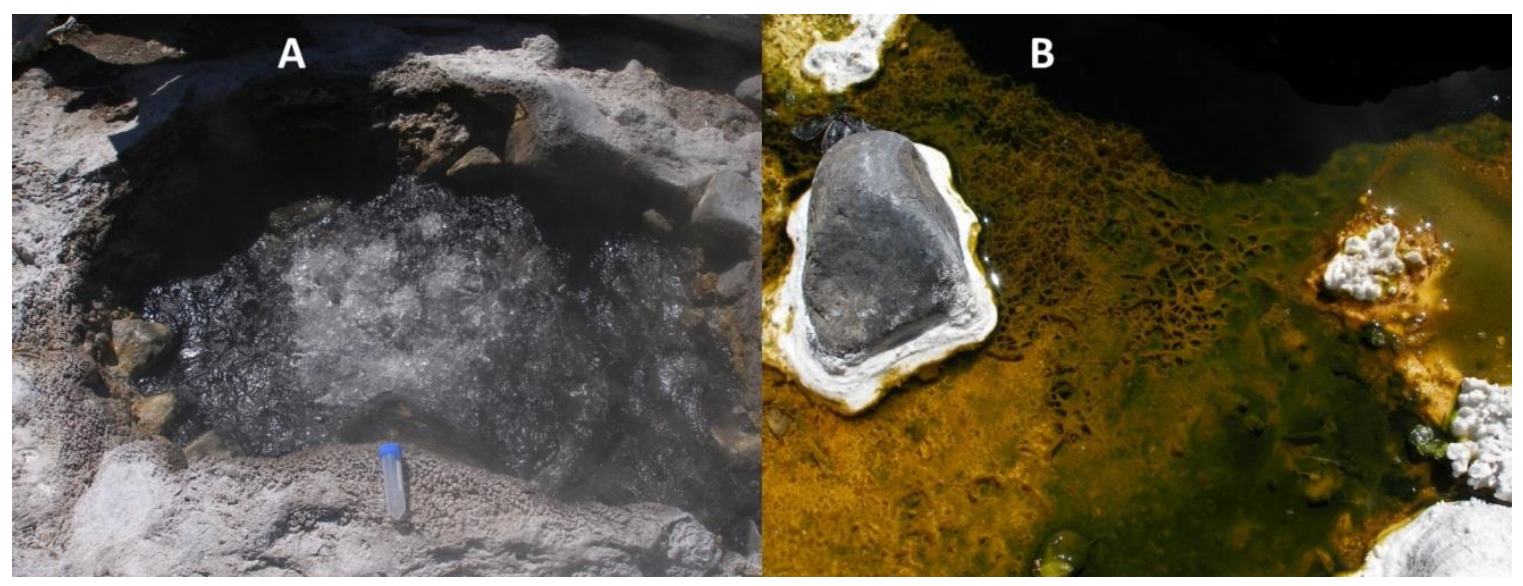

Figure 2-1. Growler Hot Spring. A: Outlet of spring $\left(95^{\circ} \mathrm{C}\right)$. B: Outflow channel at site of sinter sampling $\left(58^{\circ} \mathbf{C}\right)$.

Mickey Hot Spring is a group of geothermal springs located in the Alvord Desert of Southern Oregon (Anderson and Fairley, 2008; Lee et al., 2007); the springs range in temperature from $55^{\circ} \mathrm{C}$ to $92^{\circ} \mathrm{C}$ and are neutral and silica-depositing. One of the hottest springs (Figure 2-2) was selected and sampled from the outflow channel.

Finally, glass slides were used to create an artificial sinter to determine if nucleic acid staining could be used to identify imbedded virus particles. 


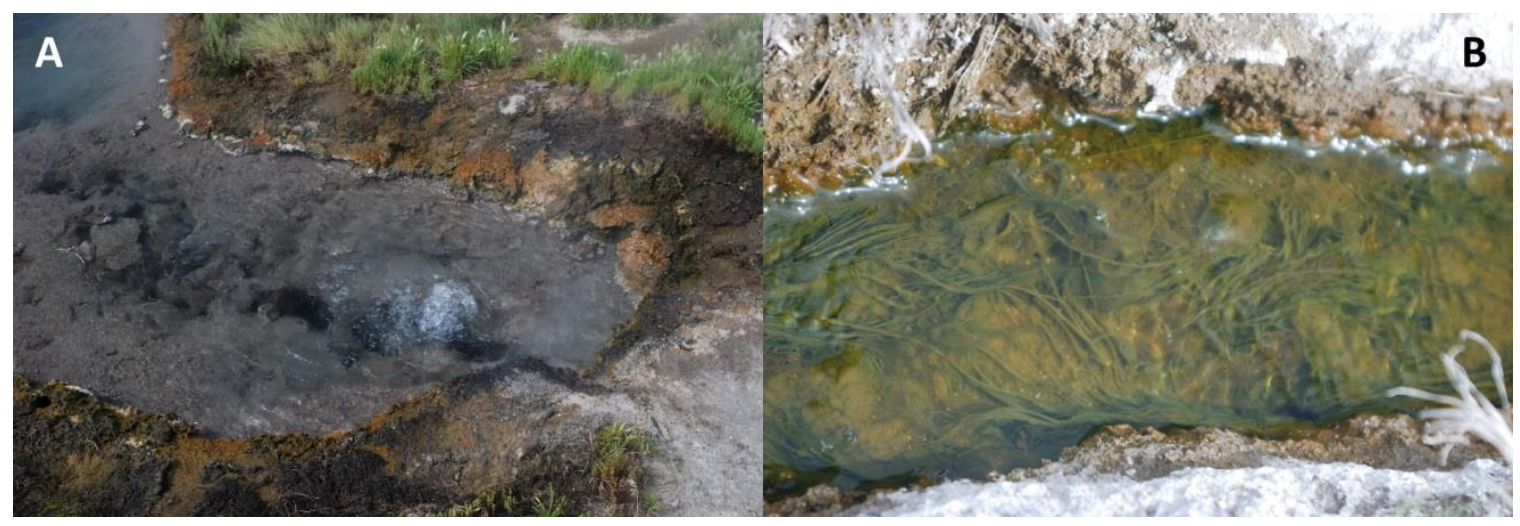

Figure 2-2. Mickey Hot Springs. A: Origin $\left(92^{\circ} \mathrm{C}\right)$. B: outflow channel at site of sinter sampling $\left(60^{\circ}\right.$ C).

\begin{tabular}{|c|c|c|c|c|c|c|c|c|}
\hline Year & Temp & $\mathbf{p H}$ & $\mathbf{N a}$ & $\mathbf{K}$ & $\mathbf{C l}$ & $\mathbf{M g}$ & $\mathbf{S i O}_{\mathbf{2}}$ & $\mathbf{S O}_{4}$ \\
\hline $1975^{*}$ & 95 & 8.3 & 63.1 & 5.19 & 67.4 & 0.0021 & 3.84 & 0.78 \\
\hline $1979 *$ & 95 & 8 & 58.3 & 4.42 & 67.7 & 0.0028 & 4.53 & 1.15 \\
\hline $1982 *$ & 95.5 & & 60.0 & 4.73 & 68.5 & 0.0004 & 4.56 & 0.94 \\
\hline 2009 & 95 & 8.2 & 59.1 & 4.5 & 67.7 & 0.0011 & 4.48 & \\
\hline
\end{tabular}

Table 2-1: Growler Hot Spring temperature, $\mathrm{pH}$ and selected solutes. Temperature is ${ }^{\circ} \mathrm{C}$ and solute concentrations are mM. * from Janik, 2010.

\section{2-2: Silicification Methods.}

\section{Virus and Host Stocks:}

Bacteriophage T4 and Escherichia coli B were obtained from Carolina Biological Supply. Bulk virus stocks were produced by inoculating $100 \mathrm{~mL}$ of log-phase E. coli B with a $1 \mathrm{~mL}$ aliquot of the laboratory virus stock with a titer of $10^{11}$ plaque-forming units per milliliter (pfu/mL) and incubated at $37^{\circ} \mathrm{C}$. After overnight incubation, the infected 
cultures were centrifuged at $3000 \mathrm{~g}$ for 30 minutes to pellet cells and cellular debris. Bulk virus stocks were stored at $4^{\circ} \mathrm{C}$ until used.

This technique produced virus titers of $10^{7}$ to $10^{8} \mathrm{pfu} / \mathrm{mL}$, which was not optimal for electron microscopy. In order to obtain high-titer virus stocks, a technique used by the laboratory of Elizabeth Kutter was employed (Carlson, 2005). This technique is a variation of the plaque assay, where virus and host are mixed together in a thin layer of solid growth medium and the viruses form plaques in a lawn of the host. A plate which had the virus plaques confluent or slightly more - sometimes referred to as a "lacy plaque" - was selected and 5-6 mL of sterile phage buffer $(100 \mathrm{mM}$ tris(hydroxymethyl)aminomethane [Tris] and $50 \mathrm{mM} \mathrm{MgCl}_{2}$ at $\mathrm{pH}$ 7.5) gently pipetted onto the surface of the plate. The plate was covered and was gently agitated for 15 to 30 minutes, after which the phage buffer was carefully removed with a sterile pipette.

Typical virus titers produced by this method were $10^{9}$ to $10^{11} \mathrm{pfu} / \mathrm{mL}$ for bacteriophage T4. This high-concentration virus stock was prepared fresh the day before each experiment and stored at $4^{\circ} \mathrm{C}$.

\section{Measuring silica concentration:}

Silica concentrations were determined colorimetrically by the heteropoly blue modification of the silicomolybdate method (Fanning and Pilson, 1973; Fishman and Friedman, 1989; Kahler, 1941). All reagents and samples were stored in polyethylene or 
polystyrene containers to prevent silica transfer from the storage vessel; the colorimetric reaction was carried out in polyethylene microcentrifuge tubes.

\section{Silicification process:}

Silicification was performed at room temperature at a final silica solution of $300 \mathrm{ppm}$ (5 $\mathrm{mM}) \mathrm{SiO}_{2}$, which simulates the conditions of some outflow channels of silica-depositing hot springs. This solution was made fresh at the start of each experiment by using granulated sodium metasilicate pentahydrate. The $\mathrm{pH}$ of the silicification solution was adjusted to between 6.8 and 7.2 with small amounts of $1.0 \mathrm{~N} \mathrm{HCl}$ immediately before use.

Nine hundred microliters of the $\mathrm{pH}$-adjusted solution was then mixed with $100 \mu \mathrm{L}$ of the virus stock and incubated at room temperature for 48 hours. A control specimen was simultaneously prepared with sterile water at a $\mathrm{pH}$ between 6.8 and 7.2 and incubated in parallel. Silicification experiments were also carried out with sterile, filtered $(0.2 \mu \mathrm{m})$ water from a known silica-depositing hot spring, "The Growler", located near Lassen Volcanic

National Park (Thompson, 1983). The silica content of this spring, measured at its surface outlet, was 230-270 ppm $\mathrm{SiO}_{2}$ (Thompson, 1983), but at the time of the experiment the silica content of the spring water sample had dropped to $104 \mathrm{ppm}$, probably due to being stored at room temperature. The silica concentration was adjusted to $300 \mathrm{ppm}$ with the addition of freshly made sodium metasilicate concentrate, and the resulting solution was promptly used for silicification. 


\section{Electron Microscopy:}

Specimens were prepared by dialyzing a $50-100 \mu \mathrm{L}$ aliquot of the treated viruscontaining solution against deionized water with a Millipore VSWP $(0.025 \mathrm{~mm}$ pore $)$ membrane for 1 hour to remove residual dissolved silica. A $5 \mu \mathrm{L}$ drop of the dialyzed solution was placed on a 400 mesh copper grid with a carbon-Formvar film (Ted Pella, Inc.) and allowed to remain for 2 minutes before wicking away the remaining liquid. The grids were then negatively stained with $2 \%$ uranyl acetate for 30 seconds, after which time the remaining stain was removed by wicking. The grids were then air dried and stored in a dust-tight container until imaging.

Transmission electron micrographs were obtained by a JEOL 100CX transmission electron microscope (TEM) with a Gatan 782 ES500W CCD camera using an accelerating voltage of $100 \mathrm{kV}$. High- resolution imaging and energy dispersive X-ray spectrophotometry (EDX) were performed on an FEI Tecnai F-20 TEM (accelerating voltage $200 \mathrm{kV}$ ) with an EDAX EDX system, which provides "real time" monitoring of the X-ray peaks as the exposure progresses. EDX was performed with a raster-scanned $15 \mathrm{~nm}$ electron beam, and the elemental peaks were identified by their characteristic energy (Bearden, 1967). The EDX was performed by scanning the electron beam over a rectangular region of the virus capsid and a control area of the grid of identical size that lacked virus particles. Comparison with unsilicified bacteriophage T4 was done with the same technique. A longer exposure time was used on the unsilicified bacteriophage T4 when no silicon peak was seen at shorter exposures; this was done to rule out the possibility that silicon in the interior of the virus was somehow "shielded" by the capsid. 


\section{2-3: Environmental sinter collection, preparation and examination.}

Subaerial sinter was removed from the outflow channel and immediately immersed in $2 \%$ glutaraldehyde solution in a sealed polypropylene container. Once back in the laboratory, the sinter was broken into a fine powder by gently crushing it in a porcelain mortar and pestle. The environmental sinters were so friable that they usually broke apart in the glutaraldehyde solution during transport and required minimal force to reduce them to powder. Once the sinter was broken up, it was rinsed with one milliliter of sterile distilled water and the resulting slurry spread onto glass microscope slides using the technique used to make thin film blood smears (Davidsohn and Henry, 1974). These smears were then allowed to air dry in a clean microscope slide box to limit contamination by airborne organisms.

After drying overnight, the slides were stained by gently placing three drops of $0.01 \%$ acridine orange solution (in $\mathrm{pH} 3.5$ acetate buffer) and then gently rinsed with filtersterilized distilled water and returned to the microscope slide box to dry in the dark (Lauer et al., 1981; Siering and Ghiorse, 1997).

The prepared slides were examined under a fluorescence microscope (Carl Zeiss, Axioscope) at 500X magnification using non-fluorescent immersion oil; images were captured using an attached digital camera. 


\section{2-4: Artificial sinter synthesis, preparation and examination.}

Artificial sinters were prepared by immersing a cleaned, degreased glass microscope slide into a neutral $600 \mathrm{ppm}(10 \mathrm{mM})$ silica solution, made with $10 \mathrm{mM}$ sodium bicarbonate as a buffering agent. The $\mathrm{pH}$ was adjusted to the range of 7.0 to 7.1 with $1 \mathrm{~N}$ hydrochloric acid. Four different sinter combinations were prepared: silica alone (control), silica with bacteriophage T4 added to a calculated final titer of $10^{8} \mathrm{pfu} / \mathrm{mL}$, silica with $E$. coli added to a calculated final concentration of $10^{6}$ colony-forming units per milliliter (cfu/mL), and silica with both bacteriophage $\mathrm{T} 4$ and $E$. coli added to the above concentrations. The solutions were left unchanged for three days to allow the sinter and organisms (if present) to adhere to the slide, and then they were replaced every other day with neutral buffered $600 \mathrm{ppm}$ silica solution. After a total of fourteen days, the slides were rinsed gently in filter sterilized $(0.2 \mu \mathrm{m})$ distilled water and then stained and examined using the same procedure used with the environmental sinters (above).

\section{2-5: Results.}

\section{Silicification of bacteriophage T4:}

Preliminary experimentation (Figure 2-3) showed that silica solutions at $\mathrm{pH} 7$ rapidly polymerized, reaching near equilibrium concentrations of silica monomer (Alexander, 1954; Azaroual et al., 1997; Busey and Mesmer, 1977; Carroll et al., 1998; Chan, 1989), as measured by the molybdosilicate blue technique (Fanning and Pilson, 1973). For this reason, all silica solutions were prepared immediately prior to use. 
Initial experiments were performed with the untreated high-concentration virus stock, but the TEM imaging showed large $(50-150 \mu \mathrm{m})$ colloidal particles adhering to the viral capsid (Figure 2-4). For that reason, $100 \mu \mathrm{L}$ of the virus stock was dialyzed against sterile deionized water with a Millipore VSWP $(0.025 \mu \mathrm{m}$ pore $)$ membrane for 1 hour immediately before use to remove salts and proteins from the storage media (Marusyk and Sergeant, 1980).

To determine whether a model virus with well-defined structure would silicify in a simulated hot spring environment, bacteriophage T4 was incubated for 48 hours in a 300 ppm (5mM) silica solution and then observed by TEM. After exposure, the virus particles appeared to be coated with a conforming layer of silica, with the virus morphology clearly intact (Figures 2-5B, 2-5C). With exposures of over 72 hours, the coating appeared to become thicker (Figure 2-6); by 120 hours, the virions were very difficult to identify by morphology (Figure 2-7). In contrast, the bacteriophage T4 exposed to only water did not appear to be coated (Figures 2-5A, 2-5C). The coating was most apparent around the heads of the virus as a lighter, non-staining outline of the capsid. Tails of the silica-treated viruses appeared thicker than the untreated viruses. These differences were best observed when the treated and untreated viruses were mixed together in a 1:1 ratio immediately before placing them on the TEM grid and staining (Figure 2-5C). Similar results were obtained with actual hot spring water from the known silica-depositing hot spring, "The Growler"' (Thompson, 1983). However, the stored Growler hot spring 


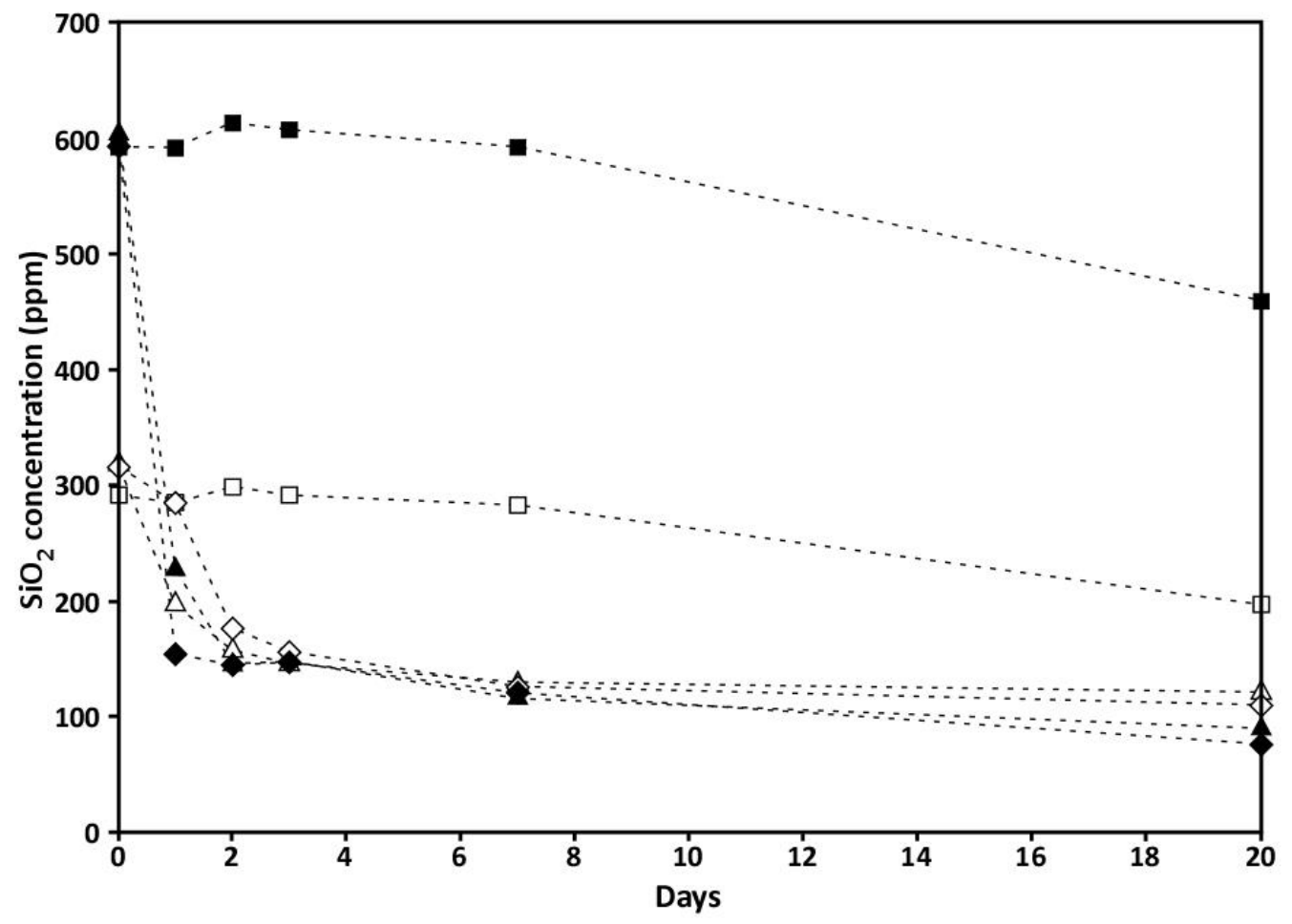

Figure 2-3. Silica monomer concentration (expressed as ppm of $\mathrm{SiO}_{2}$ ) at different $\mathrm{pH}$ and silica concentrations over time. Squares are unbuffered silica solutions at $\mathbf{p H ~ 1 1 ; ~ t r i a n g l e s ~ a r e ~ s i l i c a ~}$ solutions buffered with $10 \mathrm{mM} \mathrm{NaHCO}$ at $\mathrm{pH}$ 7; diamonds are silica solutions buffered with $10 \mathrm{mM}$ $\mathrm{NaHCO}_{3}$ and $5 \mathrm{mM} \mathrm{MgCl}_{2}$ at $\mathrm{pH}$ 7. Black (filled) symbols are for initial silica concentration of 600 ppm (10 mM) and white (open) symbols are for initial silica concentration of $300 \mathrm{ppm}(5 \mathrm{mM})$. Silica monomer concentration measured by the molybdosilicate blue technique.

water used in the experiment contained large numbers of 5-10 $\mathrm{nm}$ suspended particles (Figure 2-8A) as well as a smaller number of larger spheroids in the $25-50 \mathrm{~nm}$ range (Figure 2-8B); these were presumably silica nanocolloid which formed during storage after the water cooled. When silica-augmented Growler hot spring water was used, the coating of the virus particles incorporated these spheroids, which gave the virus a “lumpy” appearance (Figure 2-5D, Figure 2-8C). Nevertheless, virus morphology was 
clearly maintained and was very similar to that seen when the defined silica solution was used, as discussed above.

An even more extreme situation was observed when the viruses were exposed to silica solutions in Lysogeny Broth (LB; Bertani, 1951). This medium, used for virus propagation, contains relatively high concentrations of proteins and other organic molecules $(15 \mathrm{~g} / \mathrm{L})$. Under these conditions, large $(50-150 \mathrm{~nm})$ colloidal particles were formed that adhered preferentially to the virus capsid (Figure 2-4). However, these concentrations of organic molecules are not typically seen in hot spring environments (Ball et al., 2002; McCleskey et al., 2004; Wilson et al., 2000). To further characterize the silica treated virus, high-resolution transmission electron microscopy with elemental analysis (EDX) was performed (Figure 2-9). Elemental analysis revealed a recognizable silicon peak in the silica-exposed bacteriophage $\mathrm{T} 4$, which was absent both in areas of the silicified bacteriophage T4 specimen grid away from the virus particle and in bacteriophage T4 specimens that had been exposed to only water. A small phosphorus peak also was present. Since bacteriophage T4 does not possess an envelope (analogous to the cell membrane of cellular organisms) and its proteins are not known to be phosphorylated, the phosphorus signature must be from the genomic DNA in the capsid. The copper peaks are from the copper grid, and the uranium peaks are from the uranyl acetate stain used to stain the virus particles. The unexposed bacteriophage T4 specimen (Figure 2-9B) was scanned for roughly ten times longer than the silica-exposed specimen(Figure 2-9A) in order to definitively demonstrate that the unexposed virions do not contain silicon. 


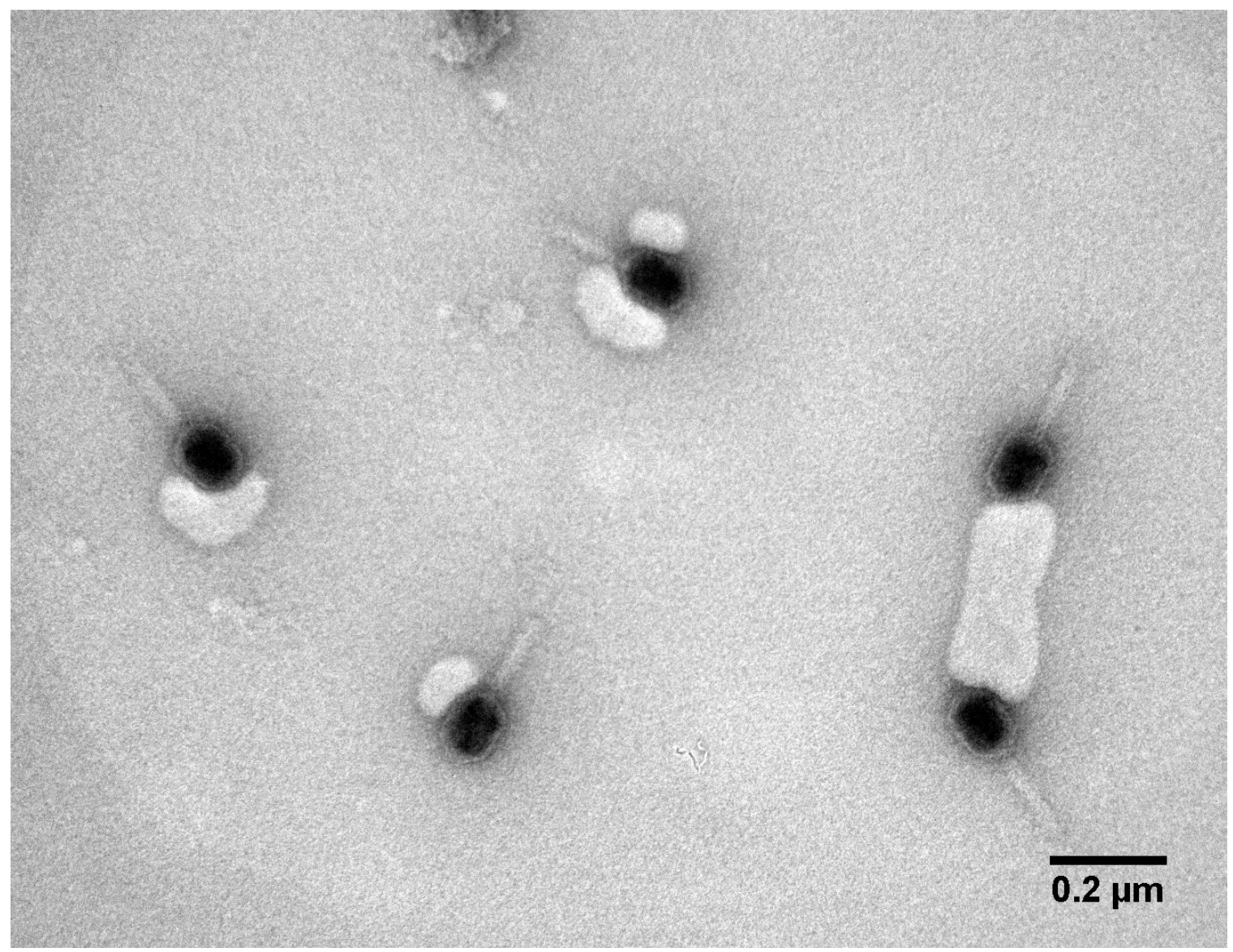

Figure 2-4. Bacteriophage T4 exposed to $300 \mathrm{ppm}$ silica without first dialyzing the virus stock to remove nutrient broth components. Negatively stained with uranyl acetate; image obtained using a JEOL $100 \mathrm{CX}$ TEM at $100 \mathrm{kV}$ accelerating voltage. 

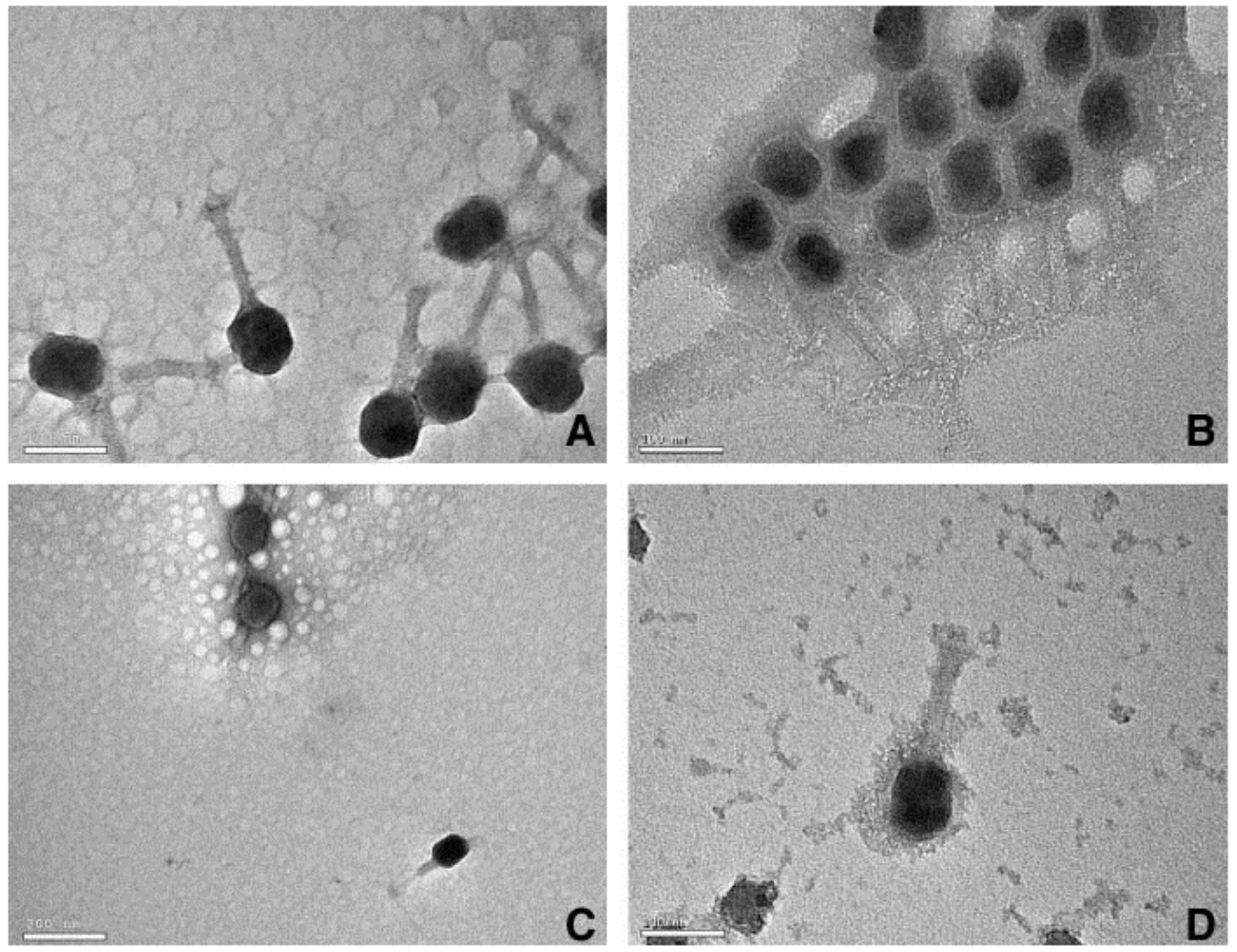

Figure 2-5. TEM images of control and silicified virus. (A) Bacteriophage T4 exposed to silica-free solution and negatively stained with uranyl acetate. (B) Bacteriophage T4 exposed to 300ppm silica for 48 hours and stained with uranyl acetate. (C) A mixture of silica exposed and control bacteriophage T4 to highlight the differences. (D) Bacteriophage T4 exposed for 48 hours to natural Growler hot spring water augmented with sodium metasilicate to a total silica concentration of 300 ppm. Scale bars are 100 $\mathrm{nm}$ in all panels except $(C)$, where it is $200 \mathrm{~nm}$. All images obtained using a JEOL 100CX TEM at $100 \mathrm{kV}$ accelerating voltage. 


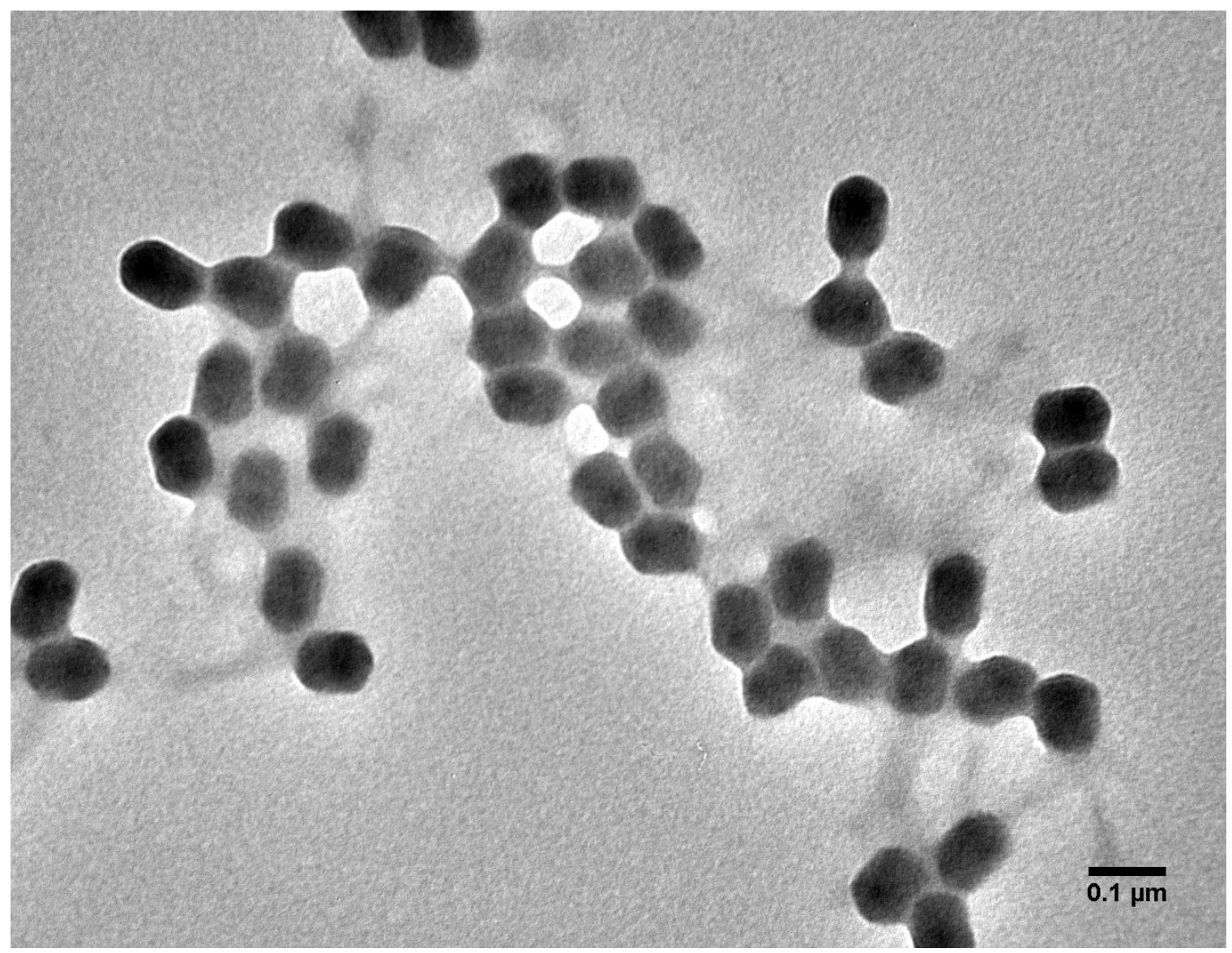

Figure 2-6. Bacteriophage T-4 exposed to $300 \mathrm{ppm}$ silica solution (pH 7) for 72 hours. Image obtained using a JEOL $100 \mathrm{CX}$ TEM at $100 \mathrm{kV}$ accelerating voltage. Negative staining with uranyl acetate.

\section{Examination of environmental sinters:}

Sinters from both locations showed a number of objects which fluoresced when stained with acridine orange (Figures 2-10 and 2-11). The images shown are typical of what was seen in the areas of the slides where the thickness of the smear was thinnest. In thicker areas of the smear, the appearance was similar to lamps in thick fog. Even in the thinnest areas of the smear, areas of bright fluorescence were surrounded by a "halo", suggesting diffraction of the light. One technical problem that arose was that the digital 


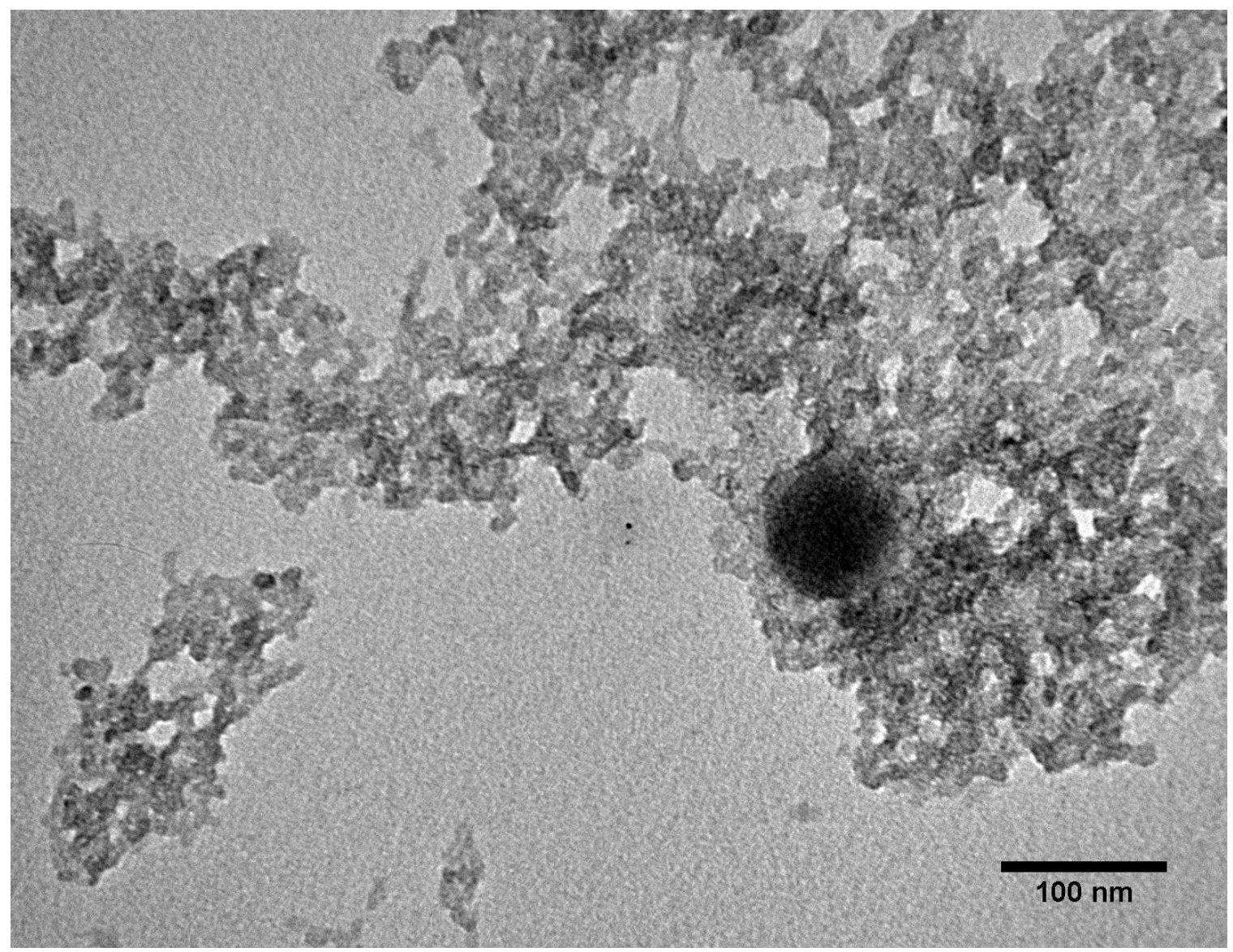

Figure 2-7. Bacteriophage T-4 exposed to $300 \mathrm{ppm}$ silica solution (pH 7) for 120 hours. Image obtained using a JEOL $100 \mathrm{CX}$ TEM at $100 \mathrm{kV}$ accelerating voltage. Negative staining with uranyl acetate.

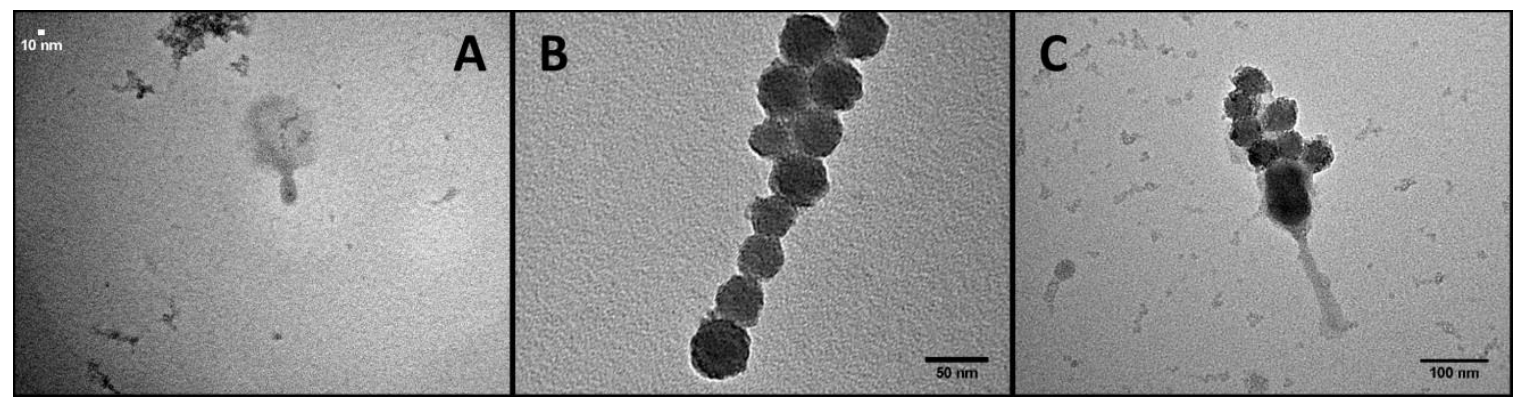

Figure 2-8. A and B are images of untreated water from Growler Hot Spring showing nanocolloid, presumed silica, in two size ranges; A: $5-10 \mathrm{~nm} ; B: 25-50 \mathrm{~nm}$. C is bacteriophage T4 silicified in a solution of Growler Hot Spring water augmented with silica to a concentration of $300 \mathrm{ppm}$. 
camera only captured a fraction of the field of view, so it is difficult to determine scale precisely.
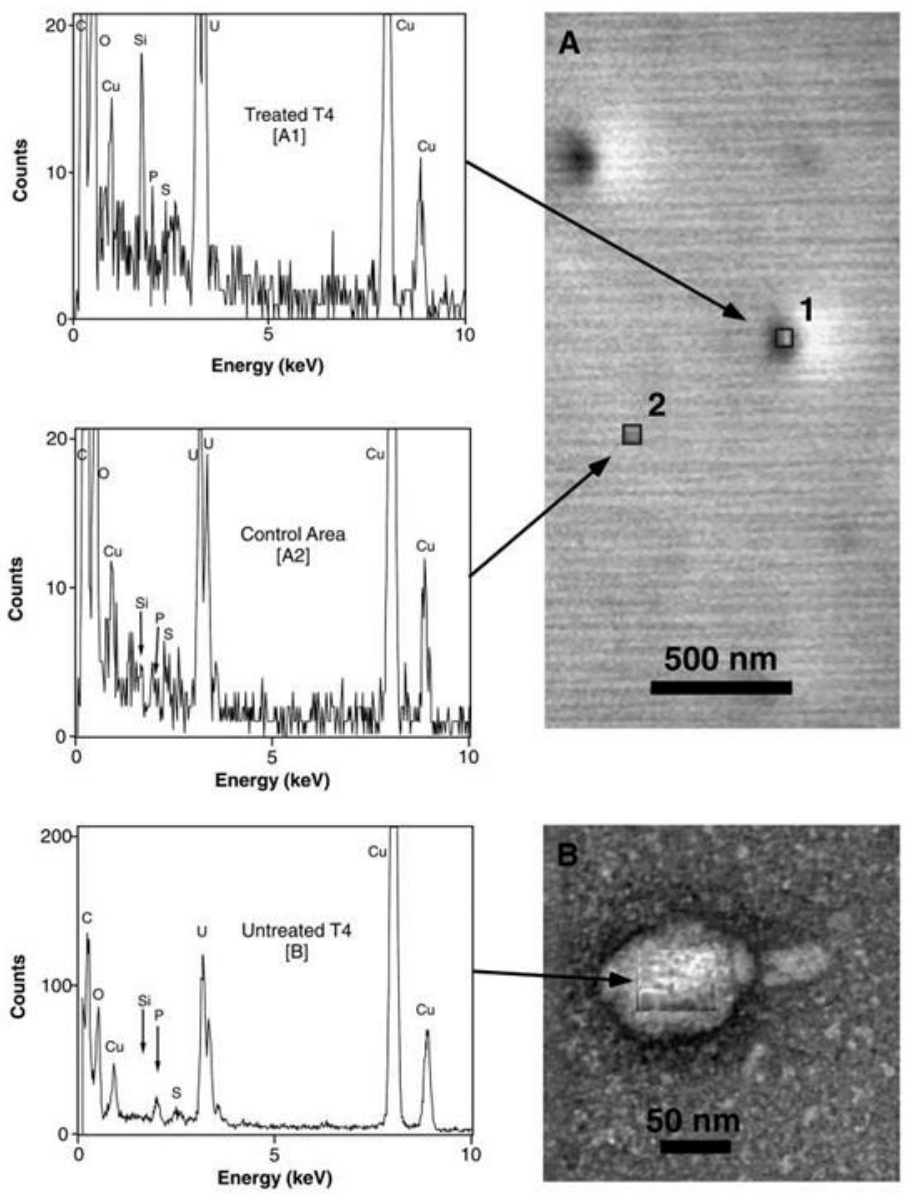

Figure 2-9. Energy-dispersive $x$-ray spectroscopy (EDX) of the capsid of a single silicified bacteriophage T4 (A1), a control region of the size on the same grid (A2), and EDX of a capsid of bacteriophage $T 4$ that had not been treated with silica solution $(B ; 15 \mathrm{~nm}$ spot size). EDX peaks are labeled. Image (A), from the targeting scan of the EDX, shows the region sampled for the treated bacteriophage T4 (labeled " 1") and the control area (labeled ' 2 "'). Image (B), a high-resolution TEM image of an untreated bacteriophage $\mathrm{T} 4$ after EDX, shows the area scanned by the electron beam. The scan in $B$ was 10 times longer than those in $\mathrm{A}$. 


\section{Artificial sinter results:}

The other preparations all looked very similar; residual host bacteria (E. coli) in the Images from the artificial sinters are shown in figure 2-12. The control preparation, with silica only, showed only faint green fluorescence with acridine orange (Figure 2-12A). bacteriophage $\mathrm{T} 4$ stock solutions apparently proliferated during the process, so all three preparations showed recognizable bacteria. None of the preparations showed the punctate spots of fluorescence of viruses seen in aqueous suspension (for example, see Suttle et al, 2007, Box 1b). There were, instead, a number of small rounded "blobs" of fluorescence which could be either viruses or small bacteria seen in Figure 2-12B-D.

\section{2-6: Discussion.}

Geochemical considerations predict that the small size of viruses, ca. $100 \mathrm{~nm}$, would preclude their silicification since even under supersaturation conditions, such as those found in silica-depositing hot spring ecosystems, the rate of silica dissolution would exceed its rate of deposition (Alexander, 1957; Conrad et al., 2007; Kobayashi et al., 2005). Results of this study have shown, however, that at silica concentrations below that needed for homogeneous or spontaneous nucleation (Weres et al., 1981), virus particles can become coated in silica (Figure 2-5). Later virus silicification studies indicate that other viruses also become silicified under similar conditions (Chapter 3) (Orange, 2011). The degree of silicification of the T4 viruses is yet to be determined; it may be that they are permineralized or they may have only a surface coating of silica. The capsid of bacteriophage $\mathrm{T} 4$ is composed of repeating interlocking proteins and is porous to small 


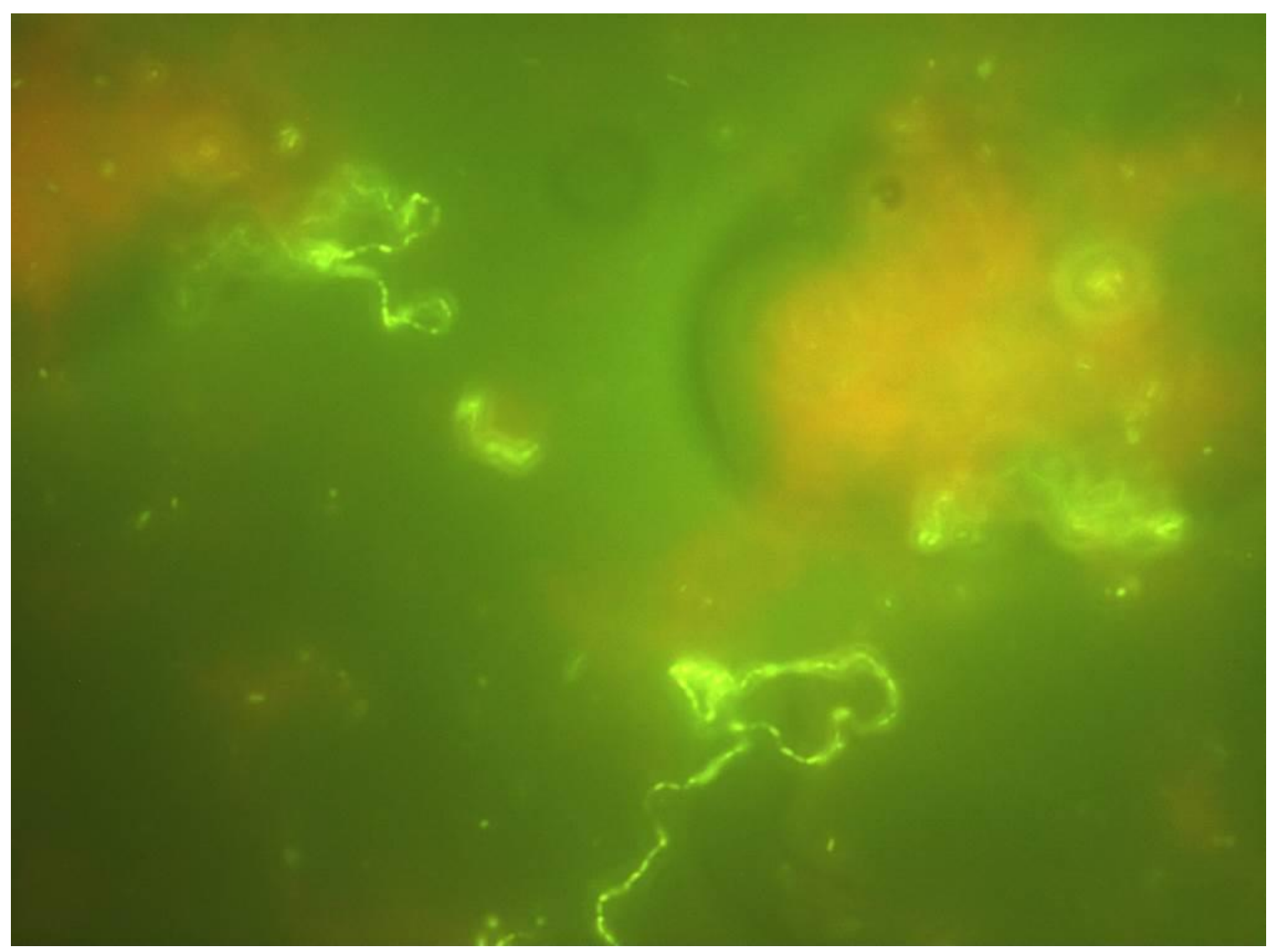

Figure 2-10: Fluorescence microscope image of Mickey Hot Spring sinter. Note "halo" in upper right corner of the image.

molecules, including the uranyl acetate used for staining. The decrease in staining of the capsid after silica treatment, seen most clearly in Figure 2-5C, suggests that the silica coating is extensive enough either to reduce the porosity of the capsid or decrease its aqueous internal volume. Still, some internal space remains, as evidenced by the diffusion of stain into the capsid.

When water from Growler Hot Spring was used to make up the silica solution, the appearance of the exposed virus was different from those exposed to silica solutions of 


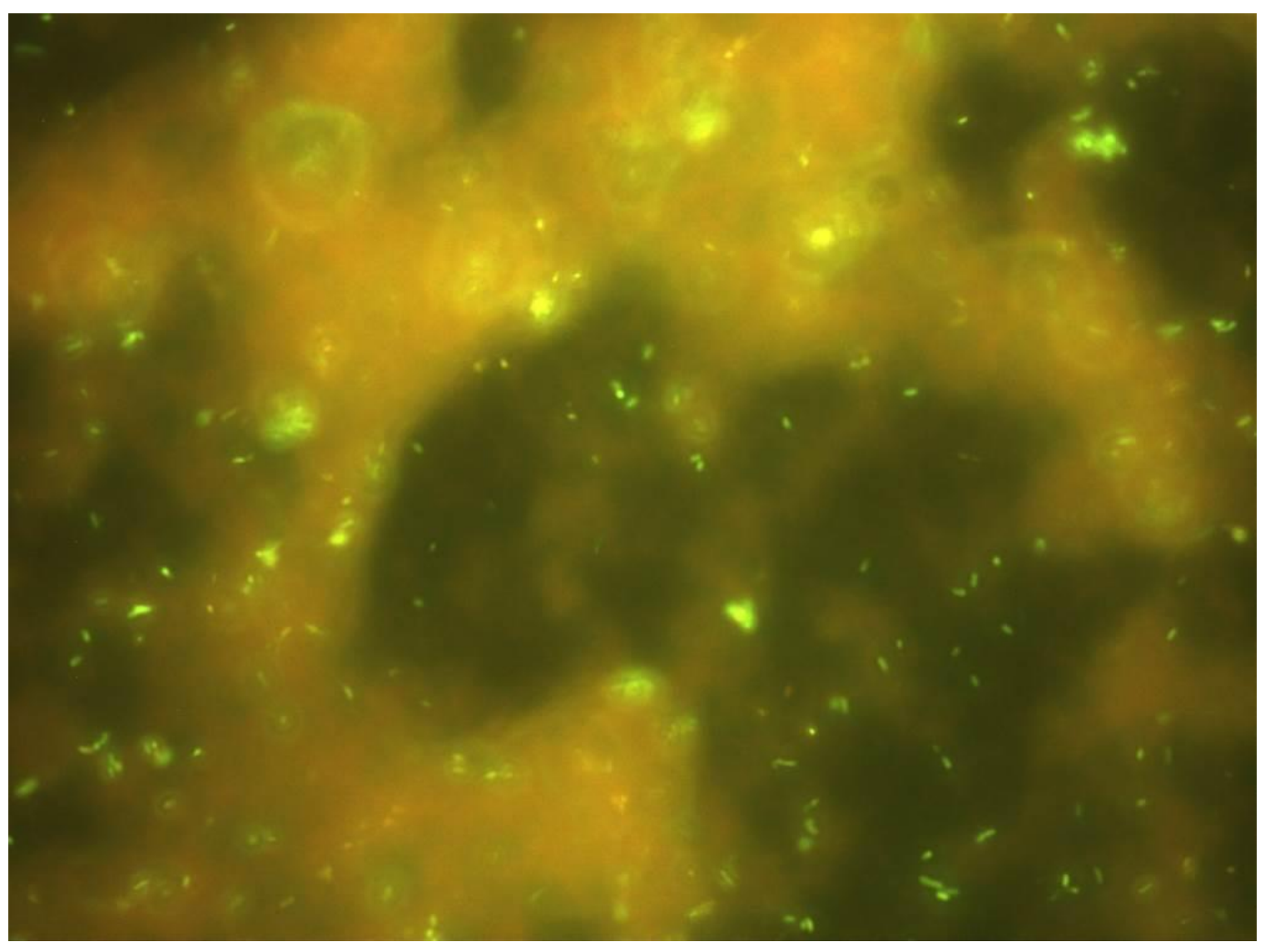

Figure 2-11: Fluorescence microscope image of Growler Hot Spring sinter. Note numerous "haloes" in the image.

the same monomeric silica concentration made from distilled water. In addition to the spheroids attached to some of the viruses (Figure 2-8C), there was a coarser appearance to the coating, suggesting that the smaller $5-10 \mathrm{~nm}$ particulate material was also incorporated into the silica coating in these experiments.

As viruses are often the only microbial predators in silica depositing hot springs, their silicification could render them non-infectious and ultimately lead to a decrease in microbial diversity in these environments (Bouvier and del Giorgio, 2007; Fuhrman, 


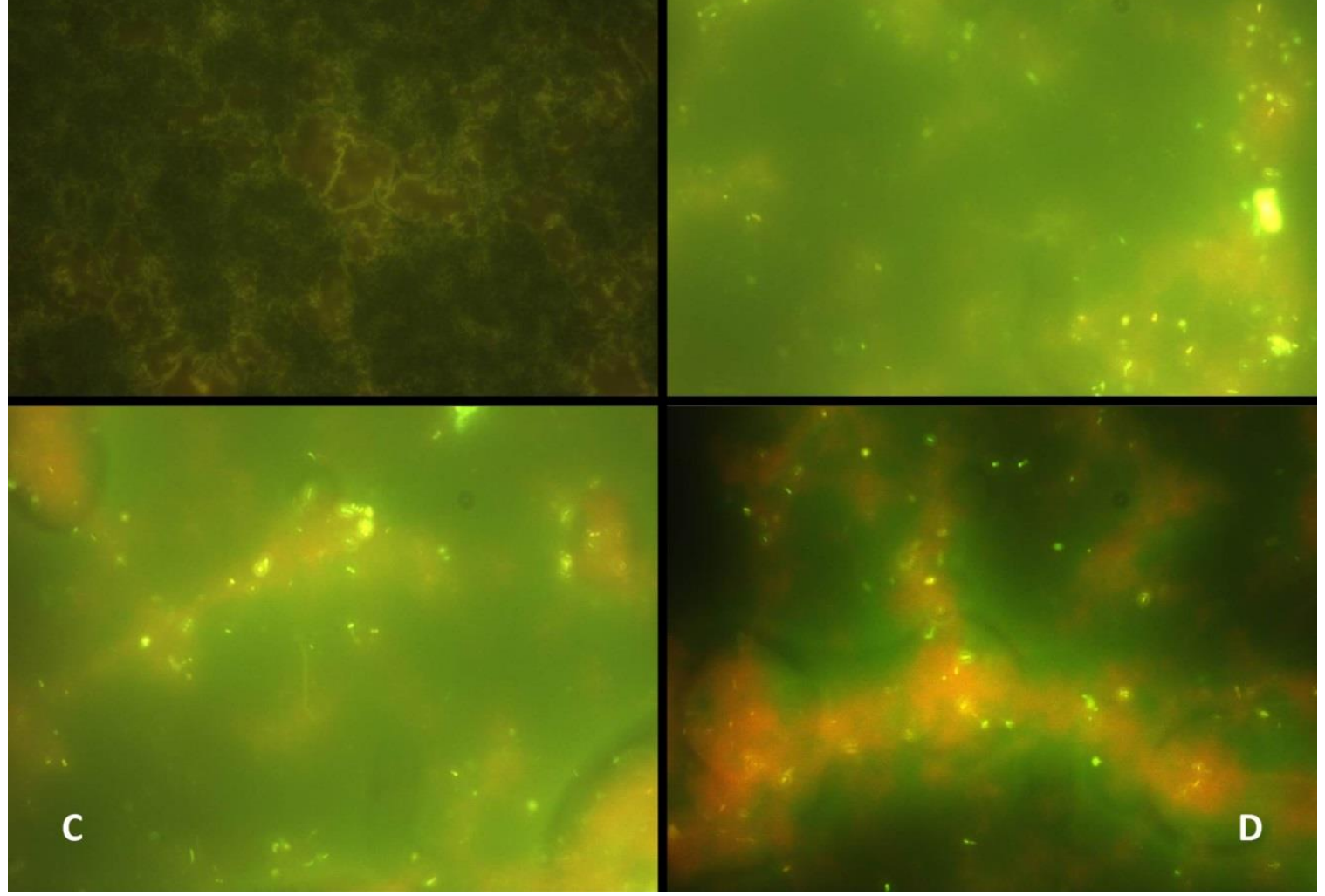

Figure 2-12: Fluorescence microscope images of artificial sinter preparations. A: silica only; B: silica and bacteriophage T4; C: silica and $E$. coli; D: silica, bacteriophage T4 and $E$. coli.

1999; Riemann and Middelboe, 2002; Suttle, 2007). A decrease in microbial diversity might manifest as a decrease in the number of species, or it could result in one speciesor a small group of species_-being dominant for a prolonged period of time, as has been reported in some studies in which hot spring microbial diversity was examined over time (Snyder, 2005; Snyder et al., 2007). Another possible outcome would be for viruses that have adapted to silica-depositing environments to have modifications of their external surfaces that reduce or eliminate silicification. This is significant in light of previous studies that have shown that different peptide sequences and functional groups can have 
markedly different affinities for silica deposition (Coradin et al., 2002; Coradin and Livage, 2001; Fang et al., 2008; Naik et al., 2002; Wallace et al., 2009). A few studies have shown that certain amino acids — histidine, lysine, and arginine-lead to increased silica binding affinity (Coradin et al., 2002; Liang et al., 2009; Naik et al., 2002), whereas amino acids with alcohol groups - tyrosine, serine, and threonine - tend to reduce silica binding (Fang et al., 2008). Therefore, structural characterization of indigenous hot spring viruses is a necessary next step in this research. Intriguingly, the coat proteins of fuselloviruses, common in acidic hot springs, are rich in lysine and arginine residues (Palm et al., 1991; Redder et al., 2009; Stedman et al., 2003; Wiedenheft et al., 2004), which should make them more susceptible to being encased in silica (see: Chapter 3).

Although the experimental findings have shown that viruses will silicify under conditions similar to those found in silica-depositing hot springs, it remains to be seen whether silicified viruses can be found in the environment. Examination of environmental sinters (Figures 2-10 and 2-11) with a fluorescent nucleic acid stain (acridine orange) failed to show any unambiguous evidence of virus present in those sinters, although other microbial life was clearly evident. The results of the artificial sinter trials (Figure 2-12) also did not indicate that viruses in sinter could be visualized by nucleic acid staining; although it is possible that other stains, such as Syber Gold, might be brighter, the problem visualizing viruses seemed to be diffusion of the light by the silica sinter, preventing the visualization of the stained viruses as points of fluorescence. 
Perhaps the most important implication of this work is that viruses coated with silica have the potential to become incorporated into the fossil record along with their microbial hosts. This study has also shown that the initial steps of the silicification process leave the virus morphologically recognizable, which raises the possibility that fossilized viruses might eventually be found. However, it remains to be seen if viruses would still be recognizable as such after the transition of the silica matrix from opal-A to other silicate minerals (Cady and Farmer, 1996; Channing and Butler, 2007; Herdianita et al., 2000; Jones and Renaut, 2007; Lynne and Campbell, 2003; Lynne et al., 2005) in the process of diagenesis.

It is possible that elemental "fingerprinting" (Figure 2-9) may aid in the detection of silicified viruses in petrographic thin sections; current high-resolution scanning electron microscope electron energy-dispersive x-ray spectroscopy (SEM-EDX) is capable of resolving particles as small as 20-30 nanometers (Hodoroaba et al., 2014), so it should be able to resolve viruses. However, the elemental signatures - phosphorus, carbon, sulfur, etc. - found in these experiments was not distinct from what would be expected from cellular debris or even phosphate minerals.

The fossilization of viruses in mineralizing environments, and the potential to preserve their biosignatures in the geological record, has profound implications for the study of viruses and their antiquity. However, the results of attempts to visualize silicified bacteriophage T4 by light microscopy (fluorescence microscopy using nucleic acid staining), TEM and elemental analysis by energy dispersive X-ray spectroscopy (EDX) 
were disappointing. While silicified bacteriophage T4 was recognizable by TEM early in the silicification process, by 72 hours, the silica accumulation was obscuring viral morphology and by 120 hours viral identification by morphology was nearly impossible. Fluorescence microscopy was also obscured by silica, which made it difficult if not impossible to distinguish between viruses and small bacteria or cellular fragments. Similarly, EDX was able to detect an elemental signature of phosphorus in silicified bacteriophage $\mathrm{T} 4$, but this signature was not materially distinct from that of cellular debris.

Having shown that one virus - bacteriophage T4 - can be silicified under environmentally relevant conditions, it is possible that viruses have been preserved to some extent in the fossil record. The next step is to determine if this is a phenomenon unique to bacteriophage $\mathrm{T} 4$ and what effect silicification has on virus infectivity and their ability to function in contemporary environments. 


\section{Chapter 3: Effects of Silicification on Virus Infectivity.}

(adapted from Laidler et al., 2013)

\section{3-1: Introduction.}

Having shown that bacteriophage T4 could be silicified (Chapter 2), the next step was to determine the effect that silicification had on virus infectivity. In addition, these experiments broadened the range of viruses tested in order to discover any differences between the tested viruses in their sensitivity to silicification.

Treating a virus with silica does not necessarily alter its infectivity. As was discussed in Chapter 2, the radius of most virus capsids is at or near the critical radius for silica deposition; the structures critical for host recognition and infection are of necessity even smaller (Aksyuk et al., 2009; Bamford et al., 1995; Bamford et al., 1976; Karam, 1994; Leiman et al., 2004; Prangishvili, 2013; Prangishvili et al., 1999). As a result, it is possible that in a head-and-tail phage like bacteriophage T4, the head could be a nucleus for silica deposition while the infection-critical structures remain unaffected (Figure 2-4).

If silicification impairs virus infectivity, there could be a number of potential impacts on viral and bacterial ecology. From a strictly viral perspective, silica-depositing environments could be expected to select against viruses that utilize lysis as part of their replication cycle. Those viruses, if their infectivity were impaired by silicification, would be at a competitive disadvantage since they are exposed to the silica-depositing environment during the extracellular phase of their replication cycle unless their host 
density was so high that the residence time in the environment was shorter than the time required for silicification (Golais et al., 2012; Hendrix and Casjens, 2006). Thus we could expect to see a higher prevalence or even predominance of viruses that employ lysogenic or other non-lytic replication strategies in silica-depositing environments.

Another potential impact of reduced viral infectivity from silicification would be reduction in microbial diversity. Viruses are important microbial predators in many environments (Hennes and Simon, 1995; Jardillier et al., 2005; Riemann and Middelboe, 2002; Taira et al., 2009; Weinbauer, 2004) and are especially adept at maintaining microbial diversity because of the "Kill the Winner" effect (Fuhrman and Schwalbach, 2003; Thingstad, 2000). Reducing viral predation by a reduction in virus infectivity would potentially lead to a reduction in microbial diversity, especially in those environments - oligotrophic and high temperature environments - where Eukaryotic microbial predators a least prevalent. Since many - if not most - silica-depositing environments are above the upper temperature limits for Eukaryotes (Baumgartner et al., 2003; Brown and Wolfe, 2006; Griffin, 1972; Tansey and Brock, 1972), this could have a significant effect on microbial diversity in those ecosystems. The larger ecology of the environment could also potentially be affected by the reduction in virus infectivity, since viruses - particularly those viruses that cause lysis of their hosts - are important in nutrient cycling, especially in aquatic environments (Fuhrman, 1999; Middelboe et al., 1996; Riemann and Middelboe, 2002; Suttle, 2005; Wilhelm and Suttle, 1999). This chapter will cover the impact of silicification on the infectivity of several different 
viruses, each with different characteristics. The reversibility of these impacts was also investigated.

\section{3-2: Methods.}

\section{Exposure System:}

Since preliminary experiments had shown that the concentration of silica monomer, as determined by the molybdosilicate blue assay (Fanning and Pilson, 1973), rapidly declined at neutral $\mathrm{pH}$ (Figure 2-3), it was necessary to develop a technique to refresh or renew the silica solution on a daily basis. Several different techniques to accomplish this were tried and abandoned. First, since the bacterial silicification studies had changed the silicification solution by centrifuging the bacteria and resuspending them in fresh media (e.g. Fein et al., 2002; Lalonde et al., 2008; Mera and Beveridge, 1993; Orange et al., 2009; Westall et al., 1995), a similar approach was tried, using an ultracentrifuge. Unfortunately, ultracentrifuging bacteriophage T4 (50,000 X g for 8 hours) led to losses of between $30 \%$ and $50 \%$ of the virus titer, measured by plaque assay (see below) even without the addition of silica. Dialysis membranes of various types were tried, beginning with placing a $100 \mu \mathrm{L}$ drop of the virus stock on a dialysis membrane (Millipore VSWP) floating in a petri dish full of the silica solution; this was not only technically challenging, requiring deft handling to avoid splashing fresh silica solution onto the top of the membrane or spilling the virus solution into the bulk solution, but it was also difficult to control for evaporative losses from the virus solution. Even when the petri dish was sealed with plastic film, the virus titers would increase by up to $20 \%$ per day, presumably 
due to concentration by evaporation. Placing the virus solution in narrow bore dialysis tubing and sealing the ends with clips eliminated the problem of evaporative losses, since the tubing was immersed in the silica solution, but there were problems of spillage and contamination when the clips failed or when samples were removed with suboptimal dexterity.

Eventually, a device consisting of a section of dialysis tubing $(8 \mathrm{~cm}$ of $10 \mathrm{~mm}$ flat width 10,000 Dalton MWCO tubing; Spectrum 133264) capped at one end with a rubber injection septum was developed, which allowed easy access for removing samples and also allowed for easy renewal of the solution surrounding the apparatus (Figure 3-1).

\section{Testing the exposure system:}

In order to reduce the risk of contamination, these dialysis systems were sterilized prior to use by immersing them in boiling water for fifteen minutes (the rubber injection septa could not tolerate autoclaving). To test whether this treatment adversely affected the characteristics of the membrane, $1 \mathrm{~mL}$ of a 1\% solution of Blue Dextran (MW 2,000,000 Da; Sigma D5751) and 1\% Neutral Red (MW 288.8 Da; Sigma N2880), pH adjusted to 6.0 with $0.1 \mathrm{~N} \mathrm{HCl}$, was placed inside two of the dialysis systems, one that had not yet been sterilized and one that had been immersed in boiling water for fifteen minutes. These were then immersed in $10 \mathrm{~mL}$ of distilled water (pH adjusted to 7.0 with $0.1 \mathrm{~N}$ $\mathrm{HCl}$ ) for one hour. After the hour had elapsed, spectrophotometric analysis of the bathing solution was used to determine how much Blue Dextran and Neutral Red had diffused across the membrane. 


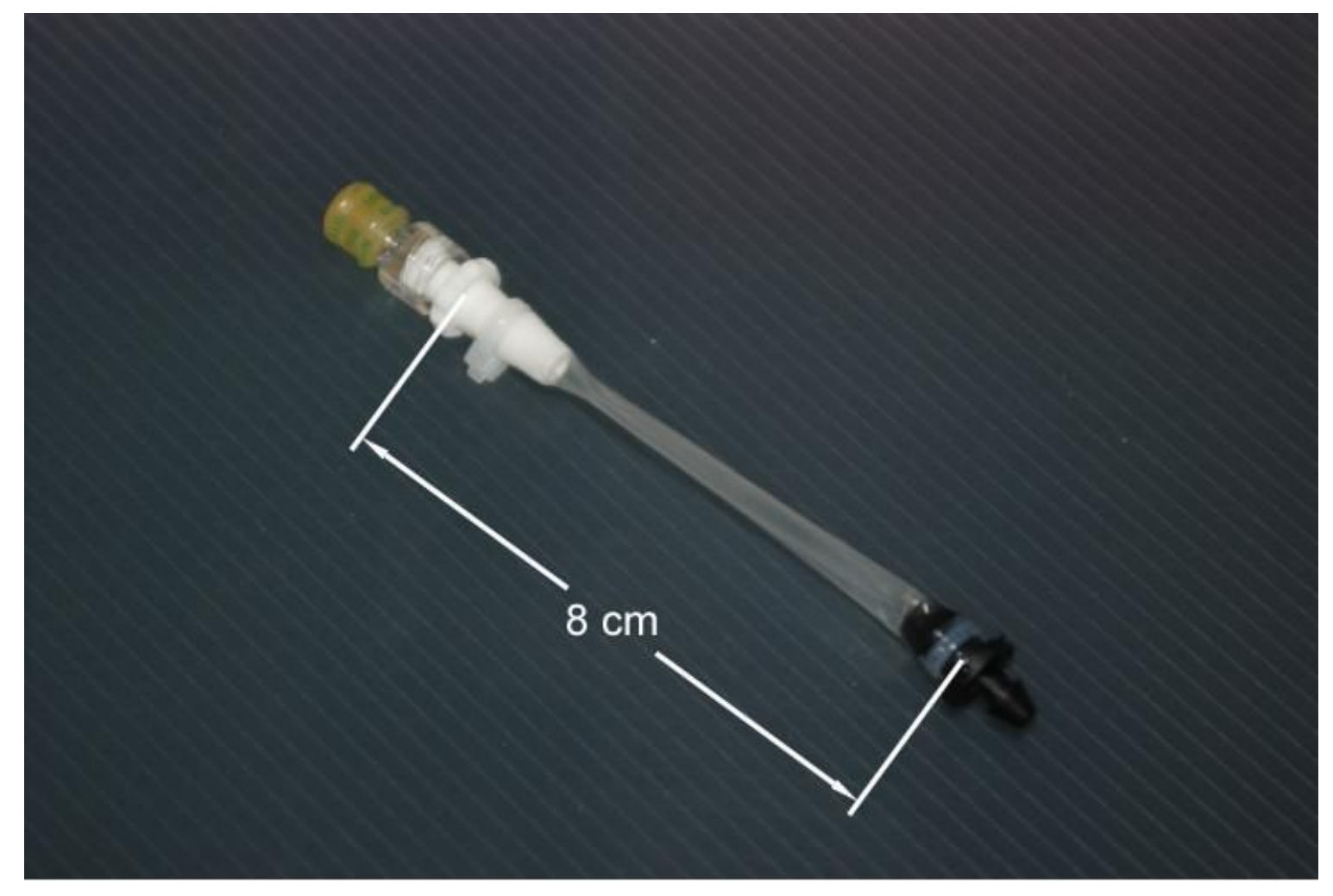

Figure 3-1. Dialysis apparatus used in infectivity experiments.

\section{Virus and Host Stocks:}

Bacteriophage T4 and Escherichia coli B, were obtained from Carolina Biological Supply, as in Chapter 2. Bacteriophage PRD1 was obtained from the Felix d'Herelle Reference Center for Bacterial Viruses. SSV-K virus stocks are maintained in the Stedman laboratory from a single colony isolate from an enrichment culture originally obtained by Dr. Stedman from hot springs in Kamchatka, Russia (Wiedenheft et al., 2004). PBCV-1 and Chlorella variabilis strain NC64A (Van Etten et al., 1983) was graciously provided by Dr. James Van Etten (University of Nebraska at Lincoln). Salmonella typhimurium LT2 (Mesquita et al., 2010) was graciously provided by 


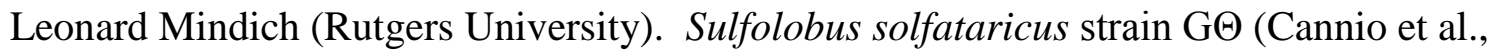
1998) was graciously provided by Raffaele Cannio (Universitá degli Studi di Napoli Federico II). Vaccinia virus (VACV) and BSC-1 cells (Carroll and Moss, 1997) were graciously provided by Keith Bajhat (Providence Cancer Center, Portland, Oregon).

Stock cultures were produced for each virus. For all but VACV, $100 \mathrm{~mL}$ of log-phase host culture (E. coli B for bacteriophage T4, S. typhimurium LT2 for bacteriophage

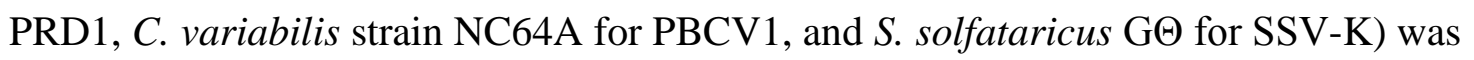
inoculated with a $1 \mathrm{~mL}$ aliquot of the laboratory virus stock and incubated at an appropriate temperature $\left(37^{\circ} \mathrm{C}\right.$ for E. coli and S. typhimurium; $20^{\circ} \mathrm{C}$ under full-spectrum fluorescent lights for C. variabilis strain NC64A; $80^{\circ} \mathrm{C}$ for $S$. solfataricus $\mathrm{G} \Theta$ ). After overnight incubation, the infected cultures were centrifuged at $3000 \mathrm{~g}$ for 30 minutes to pellet cells and cellular debris.

To maximize recovery of virus, the SSV-K culture was adjusted to $\mathrm{pH} 7.0$ with $1 \mathrm{M}$ $\mathrm{NaHCO}_{3}$ prior to centrifugation because SSV virus particles are more stable at neutral $\mathrm{pH}$ than they are at their host's optimal growth $\mathrm{pH}(\mathrm{pH} 2-3)$ (Schleper et al., 1992). After centrifugation, the supernatants were decanted and filtered through a $0.2 \mu \mathrm{m}$ surfactantfree cellulose acetate filter into sterile polypropylene containers. These virus stocks were stored at $4^{\circ} \mathrm{C}$ until used.

In order to obtain high-titer virus stocks of bacteriophage T4, bacteriophage PRD1 and PBCV-1, a technique used by the laboratory of Elizabeth Kutter was employed (Carlson, 50 
2005). This technique is a variation of the plaque assay: stored virus stock and host cells were mixed together in a thin layer of solid growth medium and the viruses formed plaques in a lawn of the host. A plate which had the virus plaques confluent or slightly more - sometimes referred to as a "lacy plaque" - was selected and $5-6 \mathrm{~mL}$ of sterile phage buffer (100 mM tris(hydroxymethyl)aminomethane), and $50 \mathrm{mM} \mathrm{MgCl}_{2}$ at $\mathrm{pH}$ 7.5) gently pipetted onto the surface of the plate. The plate was covered and gently agitated for 15 to 30 minutes, after which the phage buffer was carefully removed with a sterile pipette. Typical virus titers produced by this method were $10^{9}$ to $10^{11} \mathrm{pfu} / \mathrm{mL}$ for bacteriophage T4, bacteriophage PRD1 and PBCV1. The same technique was attempted with SSV-K, but did not yield titers above $10^{5}$, identical to that produced by infection of a planktonic host culture.

In an attempt to increase the concentration of SSV-K virus particles, $5 \mathrm{~mL}$ of a virus stock with a titer of $1 \times 10^{5} \mathrm{pfu} / \mathrm{mL}$ was concentrated (using a Vivaspin 500 system) into a volume of $100 \mu \mathrm{L}-\mathrm{a} 50$-fold reduction in volume. Plaque assay of the resulting solution gave a viral titer of only $5 \times 10^{5}$, an only five-fold increase in titer. Electron microscopy revealed that, while the original virus solution showed only rare clusters of SSV-K virus particles ("rosettes"), the concentrated solution was almost exclusively made up of clusters. This suggested that the formation of clusters is concentration-dependent and the clusters are either not infectious or result in only a single infection per cluster. Since there was no apparent benefit to concentrating the SSV-K virus further, further attempts at concentration were abandoned and virus stocks were produced by infecting log-phase host cultures and collecting the virus-containing supernatant as described above. 
Stock cultures of VACV were produced using planktonic HeLa cells using techniques

previously described (Carroll and Moss, 1997), which provided virus titers of around $10^{9}$ $\mathrm{pfu} / \mathrm{mL}$ (when thawed from frozen stock). The VACV stocks were stored at $-80^{\circ} \mathrm{C}$ until needed.

\section{Plaque Assay:}

Virus plaque assays were performed using standard techniques for bacteriophage T4 and E. coli (Karam, 1994), bacteriophage PRD1 and Salmonella LT2 (Bamford et al., 1995), VACV and BSC-1 (Carroll and Moss, 1997), SSV-K (Schleper et al., 1992) and Sulfolobus solfataricus G $\theta$ (Cannio et al., 1998), and PBCV-1 and Chlorella (Van Etten et al., 1983). In order to minimize variability from the time-dependent dissolution of the silica coating, the serial dilutions and plating were carried out as rapidly as possible with no delay between dilution and plating and the plaques were counted at 24 hours ( \pm 1 hour) from the time of initial dilution, except for VACV, which needed 48 hours to develop plaques. Incubation of the plates was done under appropriate conditions for each host ( $37^{\circ} \mathrm{C}$ for $\mathrm{E}$. coli B and $S$. enterica serovar Typhimurium LT2; $80^{\circ} \mathrm{C}$ for $S$. solfataricus $\mathrm{G \Theta} ; 20^{\circ} \mathrm{C}$ under constant illumination for $C$. variabilis strain $\mathrm{NC} 64 \mathrm{~A} ; 37^{\circ} \mathrm{C}, 5 \% \mathrm{CO}_{2}$, $100 \%$ humidity for BSC-1).

Plaque assays were performed in triplicate for each biological replicate. Plates with between 20 and 200 plaques were chosen for counting; only one plate from each technical replicate was counted for record, but plates from the next higher dilution were 
counted to validate the result. VACV plaque assays were carried out in 24 -well plates, so the maximum readable number of plaques was $\sim 30$, and only $250 \mu \mathrm{L}$ of virus solution was placed in each well, reducing the number of significant figures for these assays. VACV plaque assays were examined under a microscope at $40 \times$ magnification in order to identify the plaques by the cytopathic effect on the host cells. The mean of the assays for each biological replicate were recorded and only assays that showed technical flaws $(e . g$. failure of all or part of the lawn to grow, no plaques at any dilution) were discarded.

\section{Silicification:}

Prior to beginning the experiments, preliminary tests were performed to ensure that the viruses were stable in the base solutions. Bacteriophage T4, bacteriophage PRD1, PBCV1 and SSV-K were diluted 1:10 in a solution of $10 \mathrm{mM} \mathrm{NaHCO} 3$ and $\mathrm{MgCl}_{2}$

concentrations of $0,5,10$ and $50 \mathrm{mM}$, adjusted to $\mathrm{pH}$ of $7.0-7.1$ with $1 \mathrm{~N} \mathrm{HCl}$ prior to mixing with the virus stock. The virus titer was determined by plaque assay immediately after mixing and after five days. Because of the potential of precipitating magnesium compounds, the interaction of the ionic species in the solutions was modeled by two computer modeling programs: PHREEQC (USGS) and MINTEQ (Royal Institute of Technology, Stockholm, Sweden).

At the start of each experiment, the virus stocks were mixed 1:10 with freshly prepared silica solutions - made from sodium metasilicate pentahydrate - to yield final concentrations of 0,300 and $600 \mathrm{ppm}(0,5$ and $10 \mathrm{mM})$ silica. The solutions also 
contained $10 \mathrm{mM} \mathrm{NaHCO} 3$ (buffer) and $5 \mathrm{mM} \mathrm{MgCl}_{2}$ (to enhance stability of bacteriophage T4) and were adjusted to a $\mathrm{pH}$ of $7.0-7.1$ with $1 \mathrm{~N} \mathrm{HCl}$ immediately before use. In the VACV experiments, the silica solutions were prepared using Dulbecco's phosphate buffered saline (DPBS) as the base solution because studies had shown that VACV was more stable for prolonged periods in this solution (Kline et al., 2005; Newman et al., 2003).

The starting virus titers before silicification were approximately $10^{9} \mathrm{pfu} / \mathrm{mL}$ for bacteriophage T4, bacteriophage PRD1, PBCV1 and VACV and $10^{5} \mathrm{pfu} / \mathrm{mL}$ for SSV-K. Between 1.0 and $1.5 \mathrm{~mL}$ of each solution were then injected into individual sections of dialysis tubing that were sealed at one end by an injection septum (Figure 3-1). Each apparatus was then immersed in a $50 \mathrm{~mL}$ screw top polypropylene bottle containing 40 $\mathrm{mL}$ of solution with the same silica, $\mathrm{NaHCO}_{3}, \mathrm{MgCl}_{2}$ and $\mathrm{pH}$ as the virus solution. Three apparatus were placed in each bottle, so that all biological replicates would be exposed to exactly the same milieu.

Within ten minutes after immersing the dialysis apparatus, a $100 \mu \mathrm{L}$ sample was withdrawn for virus titer by plaque assay $\left(\mathrm{T}_{0}\right)$. These samples were withdrawn using a sterile $1 \mathrm{~mL}$ tuberculin syringe with 20 gauge hypodermic needle (standard bevel) inserted though the rubber injection septum.

The immersion solution was replaced each day with freshly prepared solution of the same composition and samples were withdrawn through the injection septum on days $1,3,8$ and 10. The virus titer of each sample was determined in triplicate by plaque assay. 
On day 10 , the immersion solution of all exposure systems was changed to a $0 \mathrm{ppm}$ silica solution, which was replaced daily. Following this change, plaque assays were done on days $12,14,16$ and $20(2,4,6$ and 10 days after the silica concentration had been reduced to essentially zero) to determine if any loss of infectivity was reversible. Only the virussilica concentration combinations that had shown an infectivity loss of at least two orders of magnitude after ten days of silica exposure were tested, along with all of the control (0 ppm silica) samples.

\section{TEM Imaging:}

A small portion of the samples of bacteriophage T4, SSV-K and bacteriophage PRD1 taken after ten days of silicification were placed on copper TEM grids covered with a carbon-Formvar film, as described in Chapter 2, and used to produce TEM images of the silicified viruses. Bacteriophage T4 and SSV-K were chosen because their infectivity had declined with silica solution exposure; bacteriophage PRD1 was selected as a representative of the two viruses (PRD1 and PBCV-1) that had not been affected by exposure to silica solution. VACV was not imaged for biosafety reasons, because it had not yet been definitively shown that VACV was irreversibly inactivated by the uranyl acetate staining process. Since the effect on infectivity was shown to be at least partially reversible, a sample of bacteriophage T4 that had been exposed to a $600 \mathrm{ppm}$ silica solution followed by ten days in $0 \mathrm{ppm}$ silica solution was also prepared for examination by TEM. 


\section{3-3: Results}

\section{Testing of exposure system:}

The dialysis membrane of the exposure apparatus showed no difference in its permeability to Blue Dextran and Neutral Red after boiling for fifteen minutes. Blue Dextran (MW 2 million Daltons) has a major lambda-max $\left(\lambda_{\max }\right.$ of $620 \mathrm{~nm}$ and a minor $\lambda_{\max }$ of $380 \mathrm{~nm}$ and Neutral Red (MW 288.8 Daltons) has a $\lambda_{\max }$ of $527 \mathrm{~nm}$ (in water below pH 6.8) (Rauf et al., 2008), so it was relatively easy to determine how much of each had crossed the dialysis membrane into the bathing solution. The level of Blue Dextran in the bathing solution was undetectable in both, while the concentration of Neutral Red in the bathing solution bathing was only $4 \%$ lower with the boiled membrane compared to the untreated membrane. In both preparations, the concentration of Neutral Red in the bathing solution was within $5 \%$ of that inside the apparatus after one hour.

\section{Virus stability in the bathing solution:}

In preliminary experiments, bacteriophage T4 maintained in neutral buffered solution (10 $\mathrm{mM} \mathrm{NaHCO} 3, \mathrm{pH} 7.0-7.1$ ) without magnesium showed a significant and steady decline in their infectivity as determined by plaque assay (see Methods section), with a loss of nearly an order of magnitude over five days. This was not unexpected, as several sources recommend that bacteriophage $\mathrm{T} 4$ storage solutions contain $10-100 \mathrm{mM}$ magnesium for 
stability (Carlson, 2005; Karam, 1994). At magnesium concentrations of 50, 10 and 5 $\mathrm{mM}$, the bacteriophage T4 infectivity remained stable for five days.

The other viruses - SSV-K, bacteriophage PRD1, PBCV-1 - do not have a documented need for magnesium to maintain infectivity, and testing showed that they were stable in neutral buffered solutions containing $0,5,10$ and $50 \mathrm{mM}$ magnesium chloride. Their silicification solutions contain magnesium in order to maintain consistency between the arms of the study. Experiments using Vaccinia virus (VACV) were carried out using a base solution of Dulbecco's phosphate buffered saline (DPBS) without magnesium because virus stability in the presence of magnesium had not been documented.

Unfortunately, the addition of magnesium to neutral solutions containing silicate ions can lead to precipitation of magnesium silicate; this was confirmed by experiment. Adding magnesium (as magnesium chloride) in concentrations of $50 \mathrm{mM}$ and $10 \mathrm{mM}$ to neutral sodium metasilicate solutions of $5 \mathrm{mM}(300 \mathrm{ppm})$ and $10 \mathrm{mM}(600 \mathrm{ppm})$ led to visible precipitation within minutes. Only when the magnesium concentration was reduced to 5 $\mathrm{mM}$ was there no immediate precipitation; these solutions ( $5 \mathrm{mM} \mathrm{MgCl}_{2}, 10 \mathrm{mM}$ $\mathrm{NaHCO}_{3}, 5$ and $10 \mathrm{mM}$ sodium metasilicate) were stable in polypropylene tubes for at least 10 days with no visible precipitation evident after centrifugation.

Since the interactions between magnesium, bicarbonate/carbonate and silicate ions was somewhat complex, due to the multiple silicate ion species present, in silico analysis of the silicification solutions was performed using two software packages (PHREEQC v3 
and MINTEQ v3). Both showed that the solutions - especially the $10 \mathrm{mM}$ (600 ppm) silica solution - were oversaturated with sepiolite, a magnesium silicate with the formula of $\mathrm{Mg}_{4} \mathrm{Si}_{6} \mathrm{O}_{15}(\mathrm{OH})_{2} \cdot 6 \mathrm{H}_{2} \mathrm{O}$. At a silica concentration of $10 \mathrm{mM}(600 \mathrm{ppm})$, sepiolite was supersaturated (saturation index 1.03) and so there is the potential for co-precipitation of sepiolite and amorphous silica. At the $5 \mathrm{mM}(300 \mathrm{ppm})$ silica concentration, none of the potential magnesium-containing mineral species were supersaturated (sepiolite saturation index 0.15$)$, suggesting that these solutions would deposit primarily silica without significant admixture of magnesium silicates.

\section{Effect of silicification on infectivity:}

Five viruses with different hosts (from all three domains of life), from different habitats and with differing surface characteristics were chosen for silicification experiments: bacteriophage T4, bacteriophage PRD1, the Chlorella virus PBCV-1, the archaeal fusellovirus SSV-K and the enveloped human virus Vaccinia (VACV).

Treating all viruses with silica concentrations of $150 \mathrm{ppm}$ and $200 \mathrm{ppm}$, both concentrations above saturation but below the levels needed for homogeneous nucleation (Chan, 1989; Verma, 2000), caused no detectable decrease in infectivity between those treatments and the $0 \mathrm{ppm}$ control for up to 10 days, so there was no further experimentation with those silica concentrations. However, the effects of 300 and 600 ppm silica treatment on virus infectivity varied from virus to virus (Figure 3-2). Treatment of bacteriophage T4 with either $300 \mathrm{ppm}(5 \mathrm{mM})$ or $600 \mathrm{ppm}(10 \mathrm{mM})$ silica 
had a dramatic effect on infectivity, with nearly three orders of magnitude loss of infectivity on exposure to $600 \mathrm{ppm}$ silica at ten days (Figure 3-2). Exposure to $600 \mathrm{ppm}$ silica solutions had a greater impact on infectivity than exposure to the $300 \mathrm{ppm}$ silica solutions. The archaeal fusellovirus SSV-K, which is indigenous to high-silica hot spring environments, had an intermediate degree of silica-induced inactivation (Figure 3-2). By
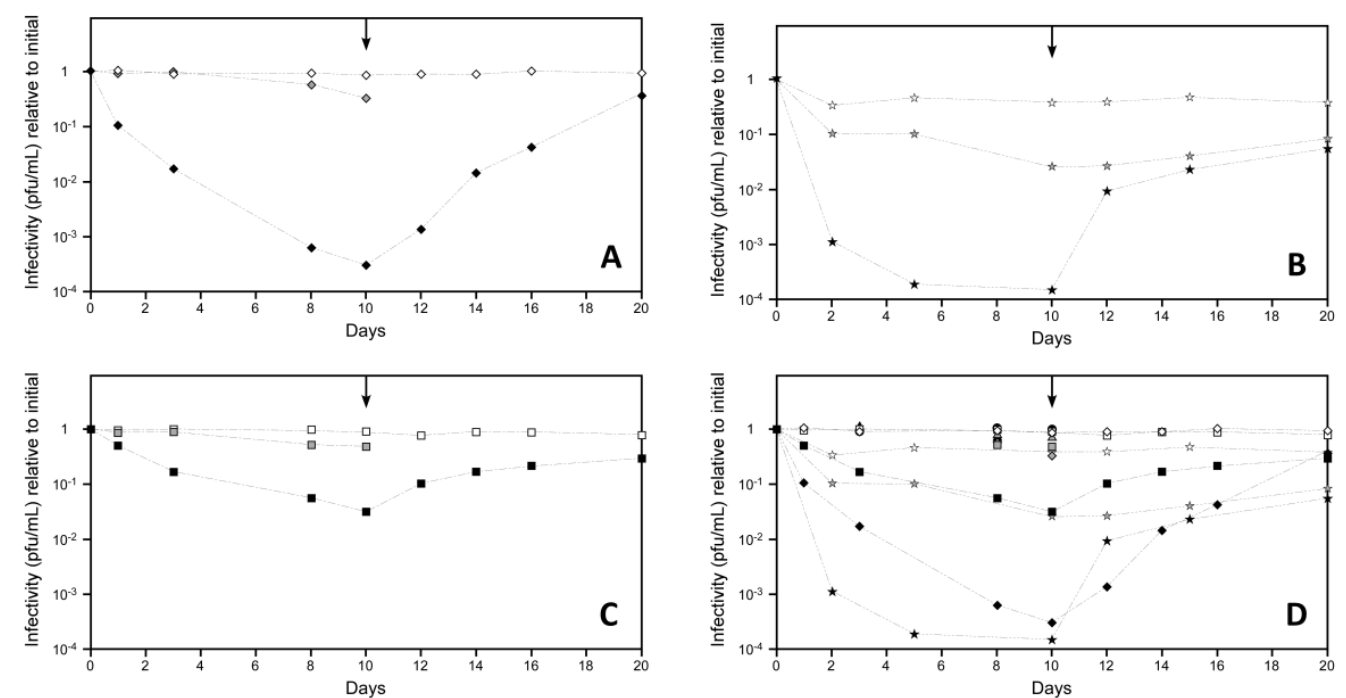

Figure 3-2. Effect of silicification on infectivity of bacteriophage T4 (diamonds), SSV-K (squares), bacteriophage PRD1 (triangles), PBCV-1 (circles) and VACV (stars), normalized to initial infectivity. Black symbols are $600 \mathrm{ppm}(10 \mathrm{mM})$ silica solution, grey symbols are $300 \mathrm{ppm}(5 \mathrm{mM})$ and white symbols are control (0 ppm silica). Vertical black arrow marks the time when the immersion solution was changed to $0 \mathrm{ppm}$ silica. All plaque assays were performed in triplicate on triplicate biological replicates except those for VACV, which had only a single biological replicate. Error bars are obscured by data point symbols. Only experiments with bacteriophage T4, SSV-K and VACV were continued past the change in immersion solution, as the other viruses showed minimal or no change in their infectivity on exposure to silica solution. A - bacteriophage T4; B - VACV; C - SSV-K; D all studied viruses.

contrast, bacteriophage PRD1 and the Chlorella virus PBCV-1 were not affected by exposure to $300 \mathrm{ppm}$ or $600 \mathrm{ppm}$ silica soltuons. The response of the well-characterized enveloped animal virus, Vaccinia (VACV) (Smith et al., 2002) to silica treatment was 
similar to that observed with bacteriophage T4 (Figure 3-2); however, since the experimental conditions were different, they cannot be directly compared.

Viruses inactivated by silicification can be reactivated merely by lowering the external silica concentration to below saturation. Following 10 days of silica exposure and maximal inactivation, both bacteriophage T4 and SSV-K regained infectivity to at least $10 \%$ of the initial titer within 10 days after the bathing solution was changed to a low silica solution (Figure 3-2A, C). Similarly, silicified VACV recovered to slightly over 5\% of its original infectivity when placed in a low silica solution (Figure 3-2B). However, since the VACV control titer also declined slightly during the course of the experiment; when the $600 \mathrm{ppm}$ silica treatment is compared to control, VACV recovered to slightly over $15 \%$ of the control titer, which was a nearly 400 -fold increase from the titer measured after 10 days of silica exposure.

\section{TEM Imaging:}

Transmission electron microscope imaging of the virus solutions after ten days of exposure to silica solution reflected what was seen in the infectivity experiments. Bacteriophage T4 virions (Figure 3-3), which was the most dramatically affected by silica exposure, had a thicker silica coating. The silicification of bacteriophage T4 was so exuberant that it was very difficult to find recognizable viral images in the $300 \mathrm{ppm}$ and 600 ppm solutions; the images shown (Figure 3-3B and 3-3C) were not necessarily representative but were, instead, the least encrusted examples that could be found. 
Compared to the granular silica coating seen with bacteriophage $\mathrm{T} 4$, the silica-exposed SSV-K (Figure 3-4) had a more lamellar silica coating, similar to that obtained in the bacteriophage T4 silicification experiments of Chapter 2. Nonetheless, as with

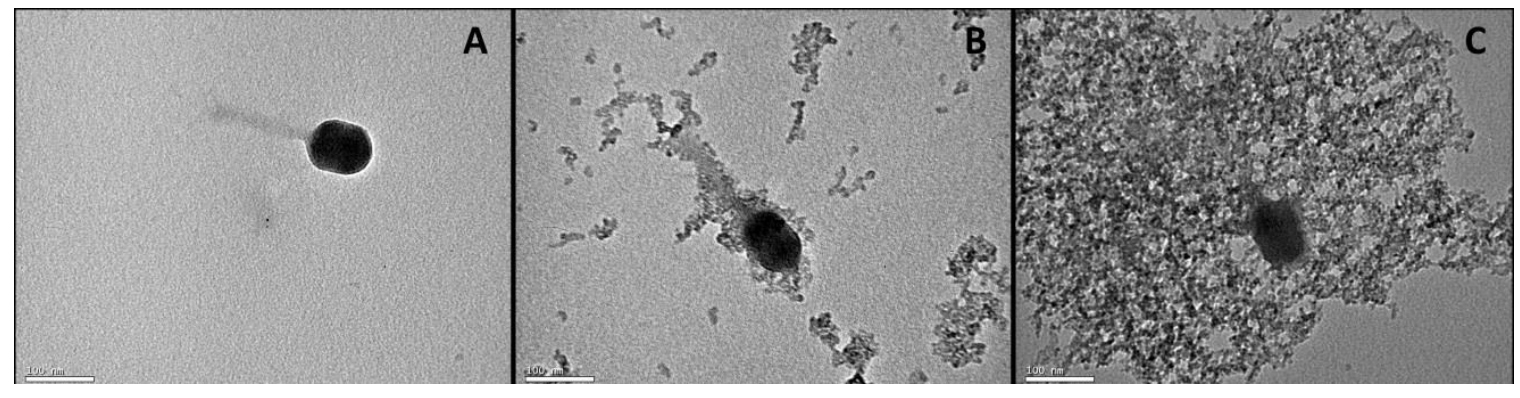

Figure 3-3. Bacteriophage T-4 virions exposed to solutions containing different concentrations of silica for ten days. A: 0 ppm silica; B: 300 ppm silica; C: 600 ppm silica. Image obtained using a JEOL 100CX TEM at $100 \mathrm{kV}$ accelerating voltage. Negative staining with uranyl acetate.

bacteriophage T4, it was difficult to find recognizable examples of SSV-K virions in the $300 \mathrm{ppm}$ and $600 \mathrm{ppm}$ silica solutions. Unlike the bacteriophage T4 preparations, the examples of silicified SSV-K were not found in contact with the granular material presumed to be precipitated silica - seen in Figure 3-3C. This is probably not a specific feature of SSV-K silicification, since similar granular material was observed in all 300 ppm and $600 \mathrm{ppm}$ preparations examined; also, the number of discernible identifiable virus particles was greatly reduced in the $300 \mathrm{ppm}$ and $600 \mathrm{ppm}$ preparations of bacteriophage T4 and SSV-K, compared to the $0 \mathrm{ppm}$ preparation of the same virus (not shown). 


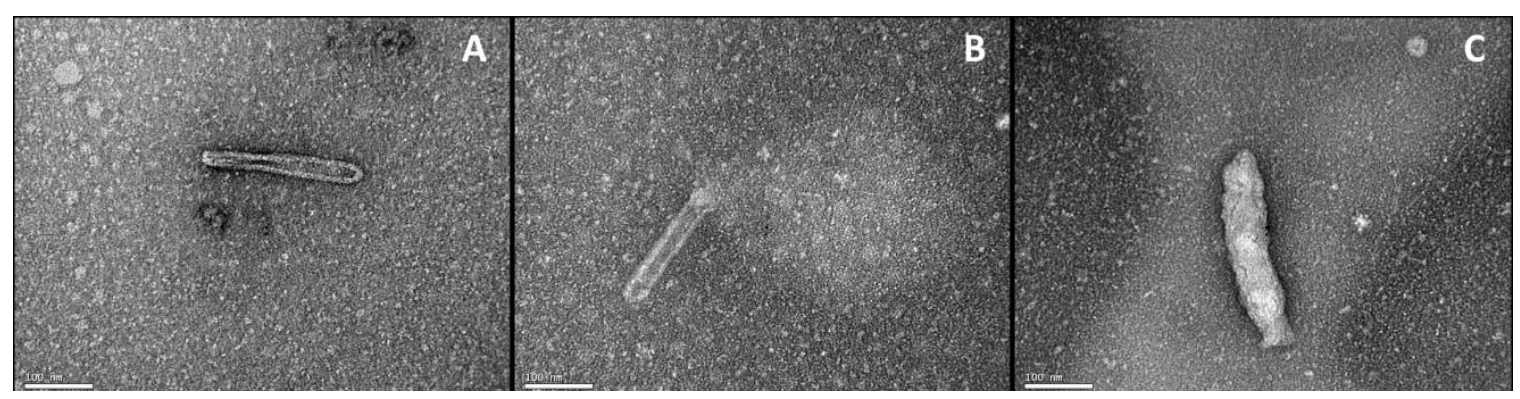

Figure 3-4. SSV-K exposed to solutions containing different concentrations of silica for ten days. A: 0 ppm silica; B: 300 ppm silica; C: $600 \mathrm{ppm}$ silica. Image obtained using a JEOL 100CX TEM at 100 $\mathrm{kV}$ accelerating voltage. Negative staining with uranyl acetate.

particles in the three different concentrations of silica (Figure 3-5). The granular material seen in the $300 \mathrm{ppm}$ and $600 \mathrm{ppm}$ preparations of bacteriophage T4 and SSV-K was also observed in the corresponding bacteriophage PRD1 preparations. Although fewer identifiable bacteriophage PRD1 virions were observed in the $300 \mathrm{ppm}$ and $600 \mathrm{ppm}$ preparations, there were more identifiable virions in those PRD1 preparations than in the corresponding bacteriophage T4 preparations (i.e. $300 \mathrm{ppm}$ and $600 \mathrm{ppm}$ ).

Bacteriophage T4 preparations after ten days of exposure to a $600 \mathrm{ppm}$ silica solution followed by ten days of exposure to a 0 ppm silica solution (Figure 3-6) contained numerous examples of disrupted bacteriophage $\mathrm{T}$, with the tails separated from the heads. The disrupted bacteriophage $\mathrm{T} 4$ outnumbered that those that were observed to be intact (Figure 3-7). Figure 3-7 shows an apparently intact bacteriophage T4 along with one with a truncated tail and an isolated and disrupted head. 


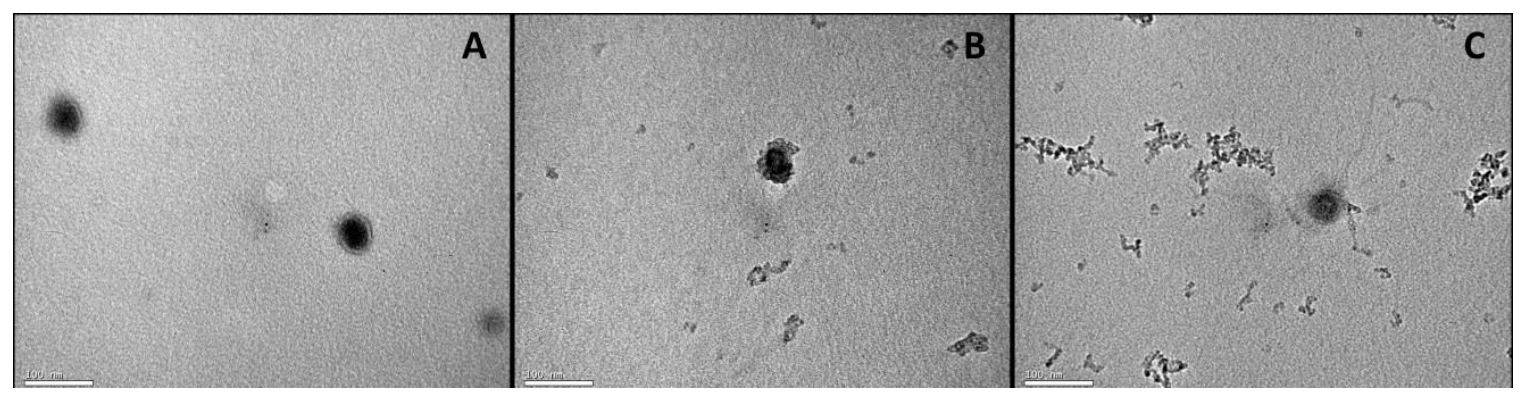

Figure 3-5. Bacteriophage PRD1 virions exposed to solutions containing different concentrations of silica for ten days. A: $0 \mathrm{ppm}$ silica; B: $300 \mathrm{ppm}$ silica; C: $600 \mathrm{ppm}$ silica. Image obtained using a JEOL 100CX TEM at $100 \mathrm{kV}$ accelerating voltage. Negative staining with uranyl acetate.

\section{3-4: Discussion}

The results of the experiments show that the viruses tested vary widely in the effect of silica exposure on their infectivity. There are a number of possible explanations for these findings, but the fact that the decline in infectivity is partially reversible constrains the range of possible hypotheses.

\section{Testing exposure apparatus:}

One of the most time-consuming aspects of these experiments was developing an exposure system that would allow the silica solution to be renewed without reducing the virus titer significantly. Enclosing the virus solution in a dialysis membrane allowed free diffusion of silica monomer - and small oligomers - from the bathing solution into the virus solution while keeping the virus contained. One concern was that techniques used to sterilize the apparatus prior to use might damage the membrane, either by causing small tears or holes or by causing the pores in the membrane to close. 


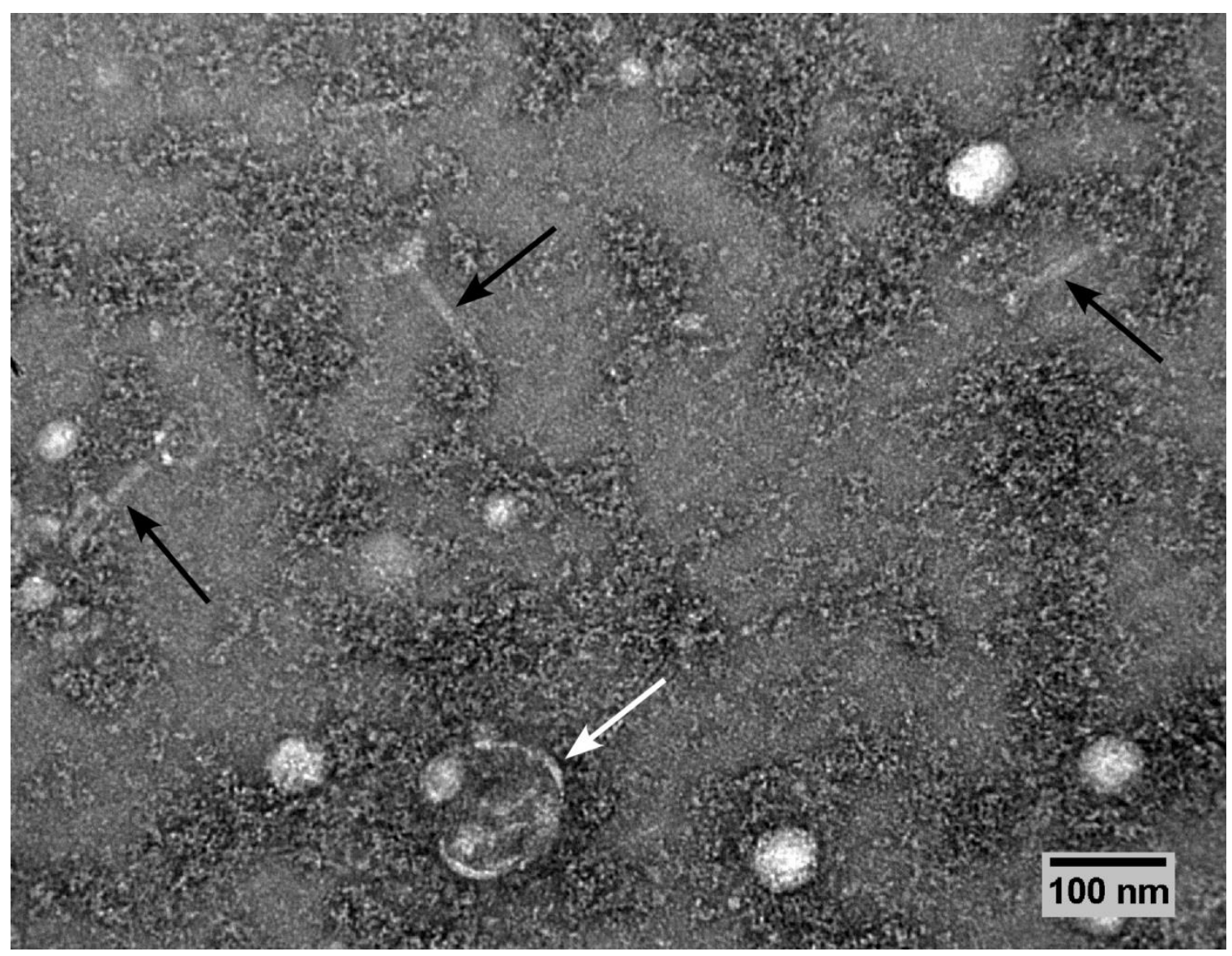

Figure 3-6. Bacteriophage T-4 exposed to $600 \mathrm{ppm}$ silica solution for ten days followed by $0 \mathrm{ppm}$ silica solution for an additional ten days. Image obtained using a JEOL $100 \mathrm{CX}$ TEM at $100 \mathrm{kV}$ accelerating voltage. Negative staining with uranyl acetate. Note the isolated bacteriophage $T 4$ tails (black arrows) and heads (white arrow).

The exposure apparatus was tested by filling it with a solution of Blue Dextran and Neutral Red and placing it in distilled water. It was expected that none of the Blue Dextran would diffuse across the membrane unless holes or tears had developed, as the size of the molecule - while still smaller than the even the smaller (30 nm diameter) rhinoviruses (McGregor and Mayor, 1971) - is significantly larger than the membrane 


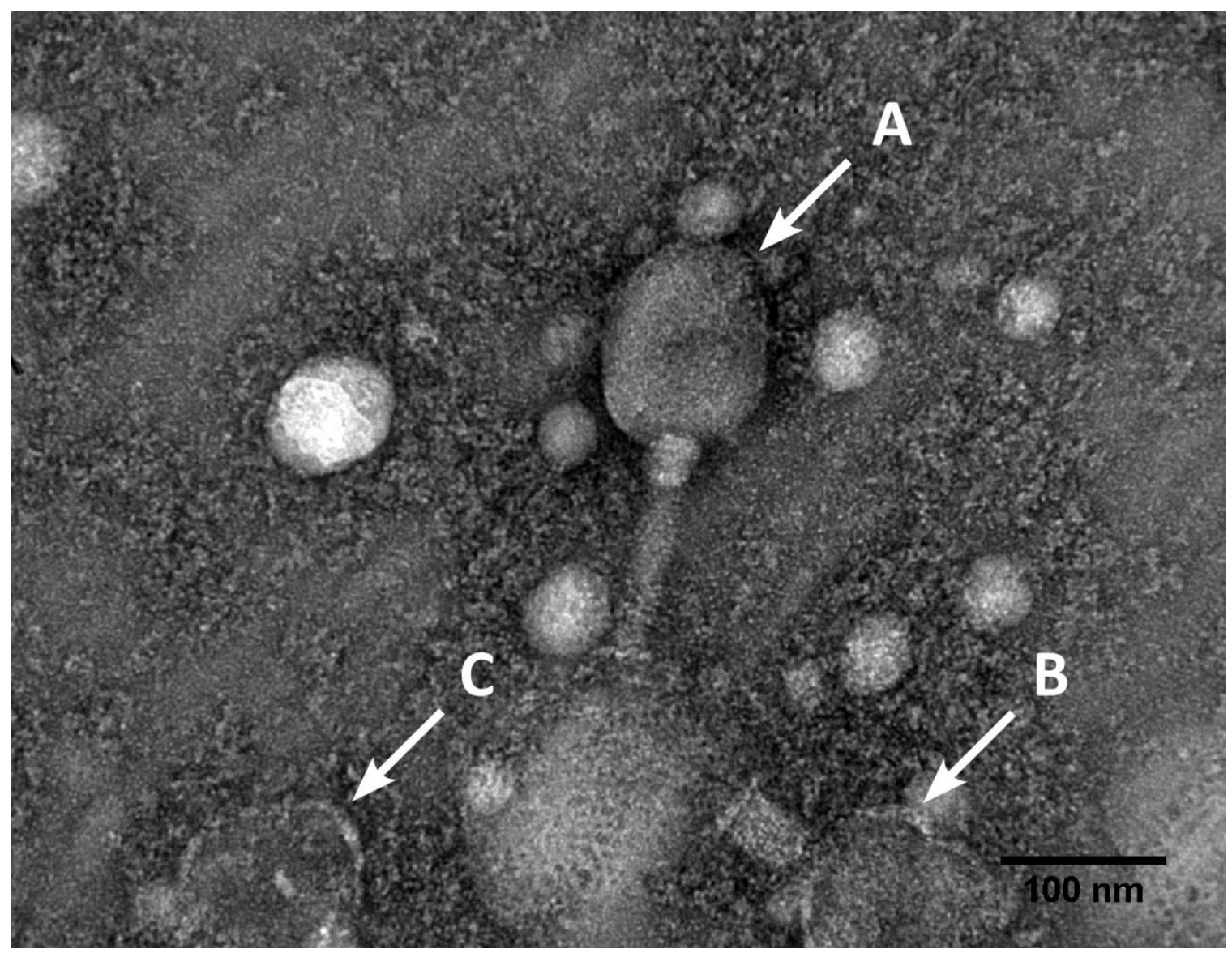

Figure 3-7. Bacteriophage T-4 exposed to $600 \mathrm{ppm}$ silica solution for ten days followed by $0 \mathrm{ppm}$ silica solution for an additional ten days. Image obtained using a JEOL $100 C X$ TEM at $100 \mathrm{kV}$ accelerating voltage. Negative staining with uranyl acetate. This image shows an apparently intact virus (A), a virus with a contracted or truncated tail (B) and an isolated bacteriophage T4 head (C).

pore size $(10 \mathrm{~nm}$, nominal). Experimental results showed that boiling the dialysis membranes did not sufficiently disrupt them to allow the Blue Dextran to cross. Neutral Red, on the other hand, with a molecular weight of $288.8 \mathrm{Da}$, is larger than silicic acid monomers (96.1 Da) and still freely diffused across the membrane (concentrations equalized across the membrane within one hour. Any change in the membrane pore number or diameter would have more effect on Neutral Red than on dissolved silica monomers, so the minimal difference in Neutral Red concentrations between the boiled 
and untreated membranes indicates that silicic acid monomers should still be able to freely diffuse across the membrane even after boiling. These apparatus, sterilized by boiling in water for fifteen minutes, were used for future experiments.

\section{Effect of silicification on virus infectivity:}

In all of these experiments, infectivity was measured by plaque assay, so discussion of the infectivity data must necessarily include a critique of plaque assay. Plaque assay is a widely used and accepted technique for determining and comparing the virus concentration in solution, introduces some potential sources of error that need to be considered. To begin with, a single plaque on the plaque assay does not necessarily correspond to a single virus particle (e.g. Jonsson et al., 2009). An individual plaque may have been caused by a single virus particle or an aggregate of many virus particles (e.g. Langlet et al, 2007). As a result, it is customary (and more precise) to refer to viral counts determined by plaque assays in terms of "plaque forming units" rather than absolute numbers. In these experiments, there is the potential for viral aggregates to form due to adhesion to silica (and other mineral) precipitates, which would reduce the number of plaque forming units without necessarily reducing the number of infectious virus particles. The findings that the number of plaque forming units did not decline in solutions of bacteriophage PRD1 and PBCV-1 exposed to silica does not eliminate this as a possible source of error, since the virus particles of bacteriophage T4, SSV-K and VACV could have surface characteristics which make them more likely to adhere to silica particles. It is entirely possible that at least some of the reduction in infectivity seen 
with silica exposure of bacteriophage T4, SSV-K and VACV may have been the result of silica-induced aggregation of virus particles (Figure 2-3). Flow cytometry could potentially illuminate the degree of aggregation by comparing silicified and control virus preparations (see Ma et al., 2013). If the virus particles are aggregating, the side scatter, which is a function of particle size, and the fluorescence signal of the stained genome of the virus would increase together. If the viruses are not aggregating, the side scatter would increase while the genome fluorescence signal would remain constant. This would give a qualitative measure of the degree of aggregation of the virus particles in the solutions.

The results - subject to the concerns mentioned above - show that bacteriophage $\mathrm{T} 4$, the archaeal virus SSV-K, and the animal virus vaccinia can be silicified and subsequently inactivated in silica concentrations similar to those found in many terrestrial hot springs (Ball et al., 2002; McCleskey et al., 2004; White et al., 1956). Based on previous silicification studies with bacteria, archaea (Benning et al., 2004a; Orange et al., 2009), and viruses (Laidler and Stedman, 2010; Orange et al., 2011) loss of virus infectivity on silicification is not unexpected. However, even in the supersaturated silica solutions used in these experiments, different viruses were not equally affected (Figure 3-2). These data strongly suggest that the surface characteristics of different viruses significantly impact the rate of silica deposition and thereby their susceptibility to inactivation. Bacteriophage T4, bacteriophage PRD1, PBCV-1 and SSV-K all have protein coats (Karam, 1994; Bamford et al., 1995; Vanetten et al., 1983; Wiedenheft et al., 2004, respectively), but have quite different inactivation profiles. Inactivation of the enveloped virus Vaccinia 
(VACV) by silica exposure was similar in magnitude to that of bacteriophage $\mathrm{T} 4$, but more rapid (Figure 3-2), yet VACV has a phospholipid membrane as its surface (Carrascosa et al., 2009).

Coradin and Livage (2001) and Coradin et al (2002) demonstrated that certain amino acids, especially those with charged side groups, increased the rate of silica polymerization in solution. Other studies (Fang et al., 2008; Naik et al., 2002) demonstrated that the presence of amino acid side chains containing hydroxyl groups (e.g serine, threonine, tyrosine) or an imidazole group (i.e. histidine) also stimulate silica deposition. Other research (Coradin and Lopez, 2003; Mera and Beveridge, 1993) has examined the interaction of silica with a variety of common functional groups, showing that phosphate groups, carboxyl residues and hydroxyl groups can all form covalent bonds with silica in solution (Figure 3-8).

In addition to covalent bonds, studies examining silica deposition on bacteria (Fein et al., 2002; Ferris et al., 1988; Mera and Beveridge, 1993; Yokoyama et al., 2004) have shown that divalent and trivalent cations, such as magnesium, calcium, iron and aluminum, can act as a "bridge" between negatively charged surface functional groups and silicate anions (Figure 3-9). This can lead to an initial non-covalent coating of silica that can act as a substrate for further silica polymerization. Taken together, these findings suggest that the functional groups exposed on the surface of viruses can have a significant impact on the rate of silica deposition and that different viruses will have different affinities for silica, even if they haven't been specifically adapted to silica-depositing environments. 
The TEM images of silica-exposed viruses (Figures 3-3 to 3-5) help shed some light on the differences in the impact of silica exposure on virus infectivity. Both silica exposure concentrations were above the supersaturation point at the temperature and $\mathrm{pH}$ of the experiments because preliminary experiments had shown that concentrations below supersaturation had no impact on the infectivity of bacteriophage T4 (see Results). As a result, there was a great deal of nanocolloidal material, presumably silica and magnesium silicate, present in the images from both the $300 \mathrm{ppm}(5 \mathrm{mM})$ and $600 \mathrm{ppm}(10 \mathrm{mM})$ preparations (for obvious reasons, none was present in the control preparations). Significantly more nanocolloid was present on TEM grids made from the $300 \mathrm{ppm}$ preparations than from the $600 \mathrm{ppm}$ preparations; this is not surprising, given the concentration differences. The nanocolloid is very similar in appearance to the $5-10 \mathrm{~nm}$ nanocolloid seen when Growler Hot Spring water was used to silicify bacteriophage T4 (Figures 2-5D and 2-8A); it was also similar in appearance to the granular material seen in the initial silicification experiments when the silicification process was extended to 120 hours (Figure 2-7). This suggests that the nanocolloid is composed of precipitated silica, since it was seen in the initial silicification experiments, which contained only silica. The kinetics of silica precipitation are such that it could take several days for a significant amount of homogenous precipitate to form (Conrad et al., 2007; Iler, 1979), which is consistent with the findings of these several experiments. The $25-50 \mathrm{~nm}$ nanocolloid found in the Growler Hot (Figure 2-8B,C) was not found in any of the other preparations, which suggests that it was created by a process that is unique to either the composition of the Growler Hot Spring water or the cooling process. 
Phosphate:

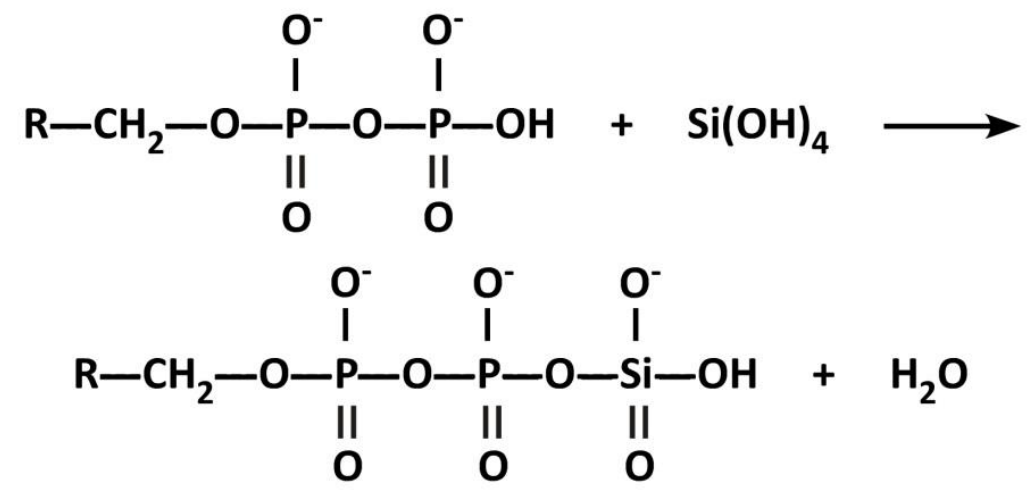

\section{Carboxyl:}<smiles>[R]C(=O)O[Si](O)(O)O[C@@H](CC)C([R])=O</smiles>

Hydroxyl/alcohol:<smiles>[R]C(O)[OH+][CH][CH]CC</smiles>

Figure 3-8. Dehydration reactions between silica monomer and various functional groups commonly found on the surface of viruses. Modified from Mera and Beveridge 1993. 


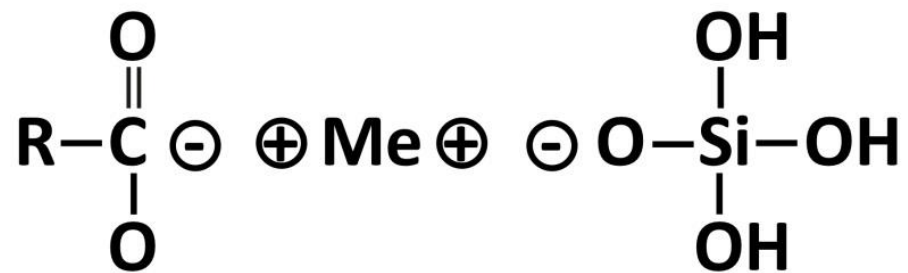

Figure 3-9. Illustrating how a divalent metal cation (Me) can act as a bridge between a negatively charged functional group (carboxylate, in this example) and silica anion.

As noted previously, the images of bacteriophage T4 showed few virus particles not embedded in the nanocolloid, especially in the $600 \mathrm{ppm}$ preparation, where only one recognizable virus particle could be found on the TEM entire grid (Figure 3-3C). The images of SSV-K and bacteriophage PRD1, while having roughly equal amounts of nanocolloid in preparations of the same silica concentration, had more virus particles free of the nanocolloid, although there were still far fewer particles than were visible in the silica-free preparations. Looking at the visible virus particles, there are some interesting qualitative differences between them. All of the visible bacteriophage T4 particles had a great deal of adherent nanocolloid, more in the $600 \mathrm{ppm}$ preparation than in the $300 \mathrm{ppm}$ preparation, covering the entire capsid and tail. In the SSV-K preparations, the silicaexposed virus particles showed increasing thickening of the surface with increasing silica concentration but none of the visible virus particles showed encrustation with nanocolloid, in stark contrast to what was seen in the bacteriophage T4 preparations. The 
bacteriophage PRD1 preparations showed neither encrustation nor surface thickening, which is consistent with the lack of effect of silica exposure on bacteriophage PRD1 infectivity.

All three of these viruses were exposed to identical silica-containing solutions at the same temperature and $\mathrm{pH}$, so the differences in both the effect on infectivity and the TEM appearance after exposure to these solutions are intriguing. Bacteriophage T4 was seen to be luxuriantly encrusted with nanocolloid, even at $300 \mathrm{ppm}(5 \mathrm{mM})$ silica concentration, while the coating seen on SSV-K was lamellar, with no apparent encrustation by nanocolloid; bacteriophage T4 was significantly more affected by silica exposure than SSV-K, which may be the result of differences in the character of silicification in those two viruses. Bacteriophage PRD1, which was unaffected by silica exposure, showed neither a lamellar coating nor encrustation with nanocolloid; these findings appear to be related, although further detailed study of the nature of the silica interaction with the viral surface is needed before the exact nature of this interaction can be known. Since the tail structure and tail fibers of bacteriophage are critically important in successful infection of hosts (Leiman et al., 2004), occlusion or obstruction of these structure could potentially impair infectivity. SSV-K also has tail fibers, like other members of the Fuselloviridae (Redder et al., 2009; Rice et al., 2004; Schleper et al., 1992; Zillig et al., 1996), which are presumed to be involved in host attachment and infection, but the lamellar silica coating seen on the SSV-K may not have extended over the tail fibers, since their radius is so much smaller than that of the viral capsid. 
Further investigation of the interaction between the virus surface and silica could help explain both the differences in the appearance of the silica coating and its effects on infectivity. Thin section TEM might be able to reveal some gross details of the contact between the virus surface and the silica, but it lacks the resolution to show the nature of the interaction. Small angle x-ray scattering (SAXS) has the potential to provide information on particles in the $1-100 \mathrm{~nm}$ range, which would make it extremely useful for evaluating the nature of the silica coating on the various virus types, especially the degree of crystallinity and mineralogy of the coating (Carrado et al., 2000). SAXS has also been used to determine the structure of disordered proteins (e.g. Bernado and Svergun, 2012) and should be able to examine the structure of the surface proteins of silicified viruses. Grazing incidence small angle x-ray scattering (GISAXS) could be even more useful in exploring the interaction at the virus surface (Abuillan et al., 2012). Regrettably, neither of these techniques was available for these studies.

While the qualitative differences between the appearances of silica-exposed bacteriophage T4, SSV-K and bacteriophage PRD1 are not diagnostic, they are distinctive, strongly suggesting differences in the characteristics of the interaction between the virus and silica, what these differences might be is harder to determine. One virion-level surface characteristic is the isoelectric point, the $\mathrm{pH}$ at which the overall charge on the virus is zero - neither positive nor negative. These data are available for bacteriophage T4 (Childs and Birnboim, 1975) and bacteriophage PRD1 (Dowd et al., 1998), but not for any of the other viruses studied. Unfortunately, the isoelectric points for bacteriophage $\mathrm{T} 4(\mathrm{pH} 4.0-5.0)$ and bacteriophage PRD1 (pH 4.2) are very similar, 
so both would have an overall negative charge at the study $\mathrm{pH}(\mathrm{pH} 7.0-7.1)$; the magnitude of that negative charge, however, cannot be readily determined from the isoelectric point. Computational modeling of the surface of the viruses could potentially indicate the amino acid functional groups exposed on the surface and their ionization state at a given $\mathrm{pH}$, if the protein structure of the virus is known with sufficient precision.

The structure of bacteriophage T4 is known to a sufficient precision, with x-ray crystal structures of the individual proteins and many of the substructures (e.g. Aksyuk et al., 2009; Fokine et al., 2004; Fokine et al., 2013; Leiman et al., 2004; Leiman et al., 2003), to potentially model the types of functional groups exposed on the surface, which makes it a good model organism for exploring the process of silicification in silico Most other viruses, including the others in these studies, are not known in such detail.

It was surprising to find that silicified bacteriophage T4, SSV-K and VACV regained from 1-4 orders of magnitude of infectivity when placed in low silica solutions (Figure 32). Beyond showing that the effect of silicification on infectivity is reversible to a significant degree under these conditions, these results indicate that the effect on infectivity was due to coating with silica rather than physical or chemical damage, which would have led to irreversible loss of infectivity. Just as with the loss of infectivity with silica exposure, there is a possibility that some or all of the recovery of infectivity when the silicified virus was exposed to silica-free solution was the result of disaggregation of viruses that were stuck to each other by silica. Since the number of infectious virus particles was determined by plaque assay, both viral aggregates and single viruses would 
create only a single plaque; this would lead to an under-estimate of the number of infectious virus particles in the event of significant aggregation.

The fact that the recovery of infectivity was not total - in fact, was less than $20 \%$ - was initially puzzling, but electron microscopy (Figures 3-6 and 3-7) helped illuminate possible reasons for this effect. The majority of the virions seen on TEM were obviously damaged and it is probable that many were damaged in ways that, although not visibly apparent, would have prevented successful infection. Figure 3-7 shows that the damage was stochastic, with some virus particles being relatively undamaged while others were catastrophically disassembled. The exact cause and mechanism of the damage is still unclear.

Since the silica appeared to be coating the virions, could it potentially protect them from environmental conditions, such as desiccation? Even if the silica coating was too porous to prevent diffusion of water, might it still be able to retard desiccation? These questions led to the next series of experiments (Chapter 4). 


\section{Chapter 4: Effects of silicification on drying tolerance}

(adapted from Laidler et al., 2013)

\section{4-1: Introduction}

In addition to the importance of viruses in animal and plant diseases (Peterson, 2008), they can also be powerful drivers of microbial diversity and are essential in recycling nutrients on a global scale (Suttle, 2007). Therefore, anything affecting virus dispersal could have profound ecological impact. One of the major disagreements in virus ecology is whether virus species are cosmopolitan (Breitbart and Rohwer, 2005) or display regional endemism. Studies on viruses in environments as diverse as volcanic hot springs, arctic ice pools and the open ocean have generated conflicting results (Angly et al., 2006). Some studies show sharp regional differences between virus genomes (Snyder et al., 2007), suggesting limited dispersal. Several others, however, have found global distribution of viruses with nearly identical genomes in many different environments (Breitbart et al., 2004a; Short and Suttle, 2005). Interestingly, one study indicates that local virus dispersal can result from aerosolization of the virus by hot spring fumaroles (Snyder et al., 2007), suggesting at least one possible host-independent dispersal mechanism.

Several studies have shown that upper level winds are capable of carrying bacteria and fungi from the Sahara Desert as far as the Caribbean Sea (Prospero et al., 2005; Smith et al., 2010). However, a critically limiting factor for wind-borne virus spread is the ability of the virus to resist drying; most viruses are highly sensitive to drying (Ding et al., 2011; 
Fogarty et al., 2008; Nakano et al., 1998) and rapidly lose infectivity when aerosolized. However, if viruses could be reversibly coated in a protective layer in addition to their capsid they could potentially spread very widely. Silica coating is a particularly attractive possibility, since there have been studies showing that viruses can be coated with silica under simulated natural hot spring conditions (Chapter 2; Orange et al., 2011). Since silica coating has been shown to have a reversible effect on viral infectivity (Chapter 3), the next step is to determine if that silica coating can provide the virus with protection from drying sufficient to allow silicified viruses to be, in theory, aerially dispersed.

\section{4-2: Methods}

\section{Virus and host stocks:}

Virus and host stocks were prepared as described in Chapter 3.

\section{Experimental methods:}

As previously described (Chapter 3) virus stocks were mixed with freshly prepared neutral ( $\mathrm{pH} 7.0$ - 7.1) sodium metasilicate solution in a buffering solution (sodium bicarbonate $10 \mathrm{mM}$ and magnesium chloride $5 \mathrm{mM}$ for T4, bacteriophage PRD1 and SSV-K; DPBS for Vaccinia) to final silica concentrations of 0, 5 and $10 \mathrm{mM}(0,300$ and $600 \mathrm{ppm})$. These solutions were then injected into sterile dialysis tubing which was in turn placed into a bathing solution of the same buffer and silica concentration. The bathing solution was replaced with freshly prepared solution daily for ten days. 
At the end of ten days of treatment, $100 \mu \mathrm{L}$ aliquots from each preparation were withdrawn through the septum in triplicate (one from each of the biological replicates) for desiccation tests. An initial trial of drying was performed with bacteriophage T4 alone, since the sensitivity of bacteriophage T4 to drying is well-established (Karam, 1994; Shapira and Kohn, 1974). In this trial experiment, the $100 \mu \mathrm{L}$ aliquots were placed in polypropylene $1.4 \mathrm{~mL}$ microcentrifuge tubes and then placed into a vacuum desiccator with fresh anhydrous calcium sulfate desiccant with cobalt chloride indicator (Indicating Drierite, W.A. Hammond Co.) at a pressure of 240 - $270 \mathrm{mBar}$ with the lids of the microcentrifuge tubes left open to allow drying. After ten days in the desiccator, the aliquots were resuspended in $1 \mathrm{~mL}$ of silica-free ( $<3 \mathrm{ppm}$ silica by molybdosilicate blue assay (Fanning and Pilson, 1973)) solution containing $10 \mathrm{mM} \mathrm{NaHCO} 3$ and $5 \mathrm{mM} \mathrm{MgCl} 2$ at $\mathrm{pH} 7.0-7.1$. One hour after resuspension, a $100 \mu \mathrm{L}$ aliquot of the solution was removed for plaque assay; ten days after resuspension, another $100 \mu \mathrm{L}$ aliquot was removed for plaque assay. During the trial experiment, it took one to two days for the aliquots to dry to the point where there was no visible liquid, which was not anticipated. In addition, not all samples dried at the same rate, apparently because of small bubbles at the bottom of the conical microcentrifuge tube, which increased the volume of the sample, increasing the surface area and surface area to volume ratio due to the tapering tube shape.

Based on the trial experiment, the final methods were modified somewhat. Only the 0 ppm and 600 ppm preparations were sampled and, as in the trial experiment, the sample aliquots to be dried were placed in polypropylene microcentrifuge tubes but the initial 
drying - except for VACV - was done in a vacuum concentrator (SpeedVac) at $4^{\circ} \mathrm{C}$ and $13 \mathrm{mBar}$ for 4 hours to rapidly dry the samples and give them simultaneous starting points. The samples were then placed in a vacuum desiccator with fresh anhydrous calcium sulfate desiccant with cobalt chloride indicator (Indicating Drierite, W.A. Hammond Co.) at a pressure of 240 - 270 mBar until time for analysis. The VACV samples - because of biosafety concerns - were air-dried at room temperature and pressure in a BSL-2 laminar-flow hood. The microcentrifuge tubes containing the VACV samples were placed in $50 \mathrm{~mL}$ polypropylene tubes and covered by filter paper to allow air exchange while reducing the chance of contamination.

After 10, 30 and 90 days of drying, one of the dried aliquots from each treatment was resuspended in $1 \mathrm{~mL}$ of either a silica-free $(<3 \mathrm{ppm}$ by molybdosilicate blue assay (Fanning and Pilson, 1973)) - solution with $10 \mathrm{mM} \mathrm{NaHCO}_{3}$ and $5 \mathrm{mM} \mathrm{MgCl}_{2}$ at $\mathrm{pH} 7$ (T4, PRD1, PBCV1, SSV-K) or Dulbecco's phosphate buffered saline (DPBS) at pH 7 (VACV). At both one hour after resuspension and ten days after resuspension, $100 \mu \mathrm{L}$ aliquots were taken from the solution and the virus titer determined by plaque assay. For the SSV-K samples, the entire $1 \mathrm{~mL}$ of rehydrated virus solution was used in the 10 day and 30 day analyses to increase the sensitivity of the plaque assay, which thus reduced the number of replicates from three to one. Plaque assays were performed using established procedures (Bamford et al., 1995; Carroll and Moss, 1997; Karam, 1994; Schleper et al., 1992; Vanetten et al., 1983). 


\section{4-3: Results}

The results of the initial drying trial with bacteriophage T4 are shown in Figure 4-1. Even in sample aliquots taken from the highest silica concentration (600 ppm), the silica concentration in the resultant reconstituted virus solution would have been only half of the saturation concentration of silica at room temperature (Carroll et al., 1998). Significantly, no plaques were seen after only one hour of resuspension in a silica-free solution, even in those preparations (300 ppm and $600 \mathrm{ppm})$ that later showed infectious virus in the plaque assay. Since the starting virus titer was $10^{9} \mathrm{pfu} / \mathrm{mL}$, the limit of resolution for these experiments - after the two 1:10 dilutions from resuspension and plaque assay aliquoting - was $10^{-7}$ relative to the initial concentration.

As shown previously (Chapter 3), the effects of 300 and 600 ppm silica treatment on virus infectivity varied from virus to virus (see Figure 3-3). Bacteriophage T4, the archaeal virus SSV-K and VACV were inactivated by $300 \mathrm{ppm}$ and 600ppm silica treatments while treatment of bacteriophage PRD1 with silica at any of the experimental concentrations had practically no effect on infectivity.

The effect of drying on infectivity varied between the viruses, in most cases closely matching the degree of silicification (Figure 4-2). Bacteriophage PRD1, which did not show any significant effect on infectivity with silica exposure, had no detectable infectivity after only ten days of drying, the shortest time tested. VACV is not shown on Figure 4-2 because the technique used was very different from that used with bacteriophage T4, SSV-K and bacteriophage PRD1. 


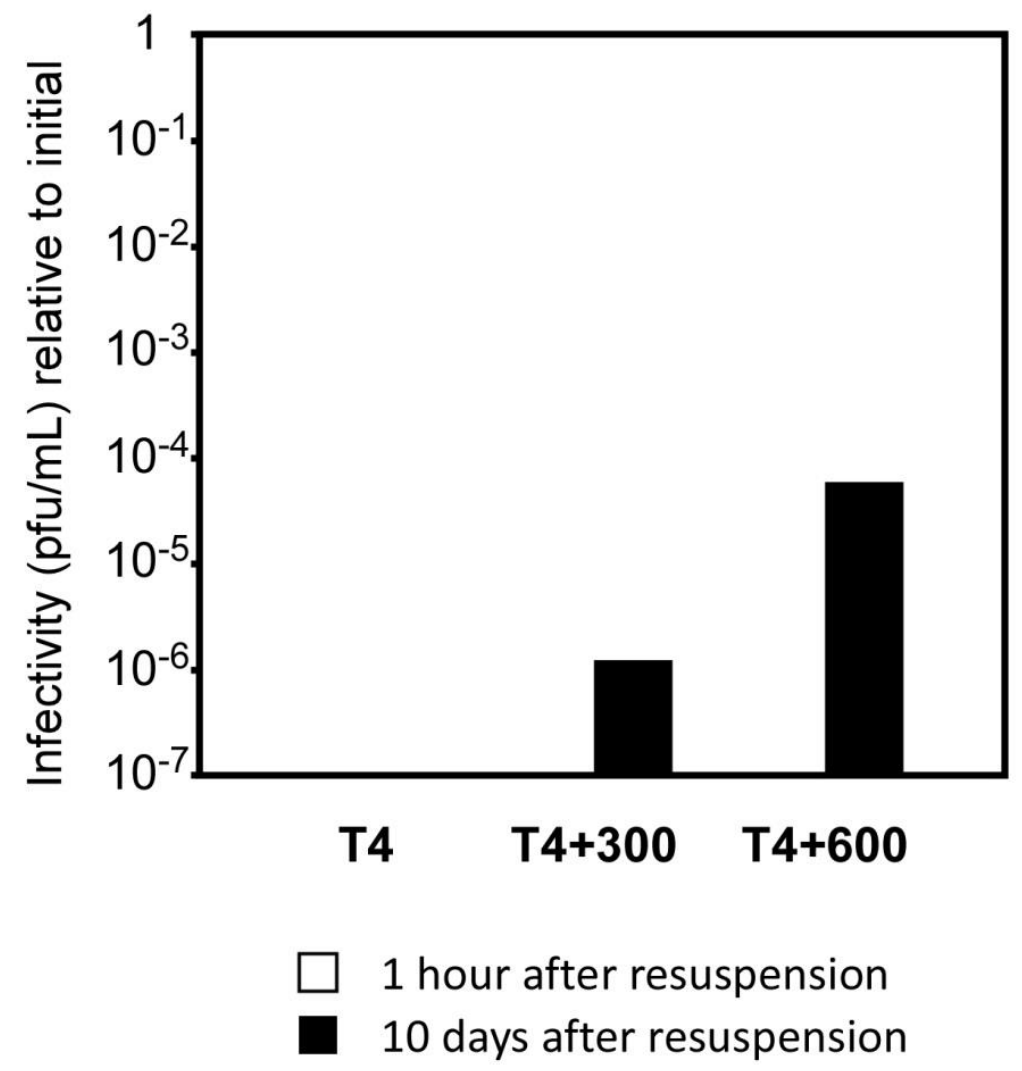

Figure 4-1.Retention of bacteriophage T4 infectivity after drying Virus drying trial results. Infectivity relative to pre-treatment for bacteriophage T4 not exposed to silica (T4), exposed to 300 ppm silica (T4+300) and exposed to $600 \mathrm{ppm}$ silica (T4+600) for ten days. White bars are the infectivity after 10 days of drying and 1 hour after resuspension; black bars are the infectivity after 10 days of drying and 10 days after resuspension. The absence of white bars is not an error - no preparation one hour after resuspension hand detectible infectivity $>10^{-7}$ relative to initial concentration.

Silicified bacteriophage T4 had detectable infectivity after up to 30 days of drying (Figure 4-2), whereas unsilicified viruses were irreversibly inactivated by ten days of drying. SSV-K was similarly protected by silicification, but to a lesser extent than bacteriophage T4 (Figure 4-2). Because SSV-K cannot be grown to similar titers to bacteriophage $\mathrm{T} 4$, the detection limit of this virus is lower, limiting the ability to compare 
their tolerance to drying at longer times. However, protection was not absolute, as there was more than a seven order of magnitude loss of infectivity of bacteriophage T4 after 60 days of desiccation, to below the limits of detection. Of the unsilicified viruses, only VACV - which is well-known for its innate tolerance to drying - had any infectivity after drying. Curiously, the drying tolerance of VACV was reduced after two days silicification. The infectivity of unsilicified VACV dropped over three orders of magnitude after drying (from $4.3 \times 10^{8} \mathrm{pfu} / \mathrm{mL}$ to $2.1 \times 10^{5} \mathrm{pfu} / \mathrm{mL}$ ) while the silicified VACV dropped over four orders of magnitude (from $4.3 \times 10^{8} \mathrm{pfu} / \mathrm{mL}$ to $1.6 \times 10^{4}$ $\mathrm{pfu} / \mathrm{mL})$.

\section{4-4: Discussion.}

In previous work (Chapter 3), it was shown that bacteriophage $\mathrm{T} 4$, the archaeal virus SSV-K, and the animal virus Vaccinia (VACV) can be silicified and thereby inactivated in silica concentrations similar to those found in terrestrial hot springs (Ball et al., 2002; McCleskey et al., 2004; White et al., 1956) and that inactivation was reversible to some extent. It was also shown that PRD1, another bacteriophage, and the Chlorella virus PBCV-1 were not significantly affected by silica exposure.

This study shows that silicified bacteriophage T4 and silicified SSV-K have enhanced tolerance to drying compared to unsilicified T4 and SSV-K (Figure 4-2) and that bacteriophage PRD1, which was not significantly affected by silica exposure, did not 


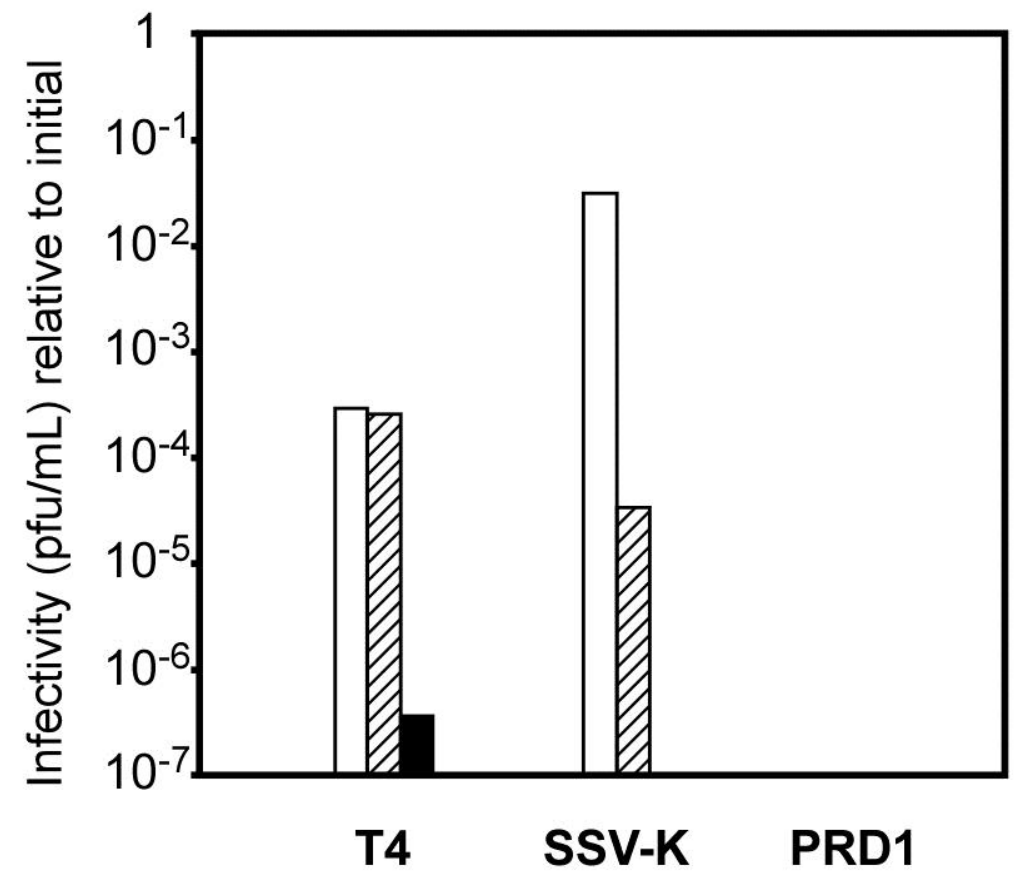

Figure 4-2. Effect of silicification on ressitance to drying. Infectivity relative to the initial value. White bars indicate infectivity after 10 days of silicification (before drying); cross-hatched bars are infectivity after 10 days of drying followed by 10 days of resuspension; black bars are is infectivity after 30 days of drying followed by 10 days of resuspension. Results from unsilicified viruses are not shown because no plaques were seen at any dilution after ten days of drying. Detection limits were 10-7 for bacteriophage T4 and bacteriophage PRD1 and 10-5 for SSV-K.

show any change in tolerance to drying after silica exposure. Curiously, the drying tolerance of VACV was reduced after two days of silicification. The infectivity of unsilicified VACV dropped three orders of magnitude, consistent with the innate tolerance to drying of the virus under the experimental conditions (Collier, 1954). The additional ten-fold loss of infectivity in the silicified VACV may be the result of damage or aggregation during the silicification process. These results indicate that, for at least some viruses, silicification may protect them from the effects of drying. 
The obvious question at this point is how relevant these findings are to environmental drying. Air at equilibrium over anhydrous calcium sulfate has an absolute humidity of $0.005 \mathrm{mg} / \mathrm{L}$ at room temperature and pressure (Bower, 1934). To put this into an environmental perspective, Table $4-1$ is a representative high-altitude atmospheric sounding from the National Oceanographic and Atmospheric Administration (NOAA) station in Salem, Oregon (KSLE), showing the temperature and humidity from the surface to over 15,000 meters.

As the data in Table 4-1 show, the atmospheric pressure inside the vacuum desiccator (250 mBar) is equivalent to that seen at 10,610 meters at the time of the sounding. At that time, the water content of the atmosphere at that altitude was $0.04 \mathrm{~g} / \mathrm{kg}$ or $0.012 \mathrm{mg} / \mathrm{L}$, over two times the moisture content of the air in the vacuum desiccator. However, the temperature at this altitude at the time of the sounding was $-50.5^{\circ} \mathrm{C}$, much lower than the experimental conditions of $20^{\circ}-25^{\circ} \mathrm{C}$. The data in Table $4-1$ also show that the tropopause - defined as the point at which atmospheric temperature stops decreasing with increasing altitude - begins at this pressure altitude, showing that the pressure and water content, but not the temperature, in the vacuum desiccator were similar to those found at the upper reaches of the troposphere.

Another issue is whether the rapid drying in the vacuum concentrator might have been less damaging to the virus than natural drying, such as would happen in an aerosol. At 


\begin{tabular}{|c|c|c|c|c|}
\hline $\begin{array}{c}\text { Press. } \\
(\mathbf{m B a r})\end{array}$ & Altitude (m) & $\begin{array}{c}\text { Temp } \\
\left({ }^{\circ} \mathbf{C}\right)\end{array}$ & $\begin{array}{c}\text { RH } \\
(\boldsymbol{\%})\end{array}$ & $\begin{array}{c}\text { Water } \\
\text { content } \\
(\mathbf{g} / \mathbf{k g})\end{array}$ \\
\hline 1003 & 61 & 23.0 & 65 & 11.47 \\
\hline 906 & 937 & 14.0 & 77 & 8.59 \\
\hline 814 & 1829 & 7.9 & 71 & 5.82 \\
\hline 700 & 3057 & 0.2 & 91 & 5.05 \\
\hline 601 & 4267 & -5.4 & 87 & 3.70 \\
\hline 500 & 5960 & -13.5 & 75 & 2.04 \\
\hline 400 & 7360 & -23.9 & 66 & 0.92 \\
\hline 300 & 9390 & -39.7 & 53 & 0.21 \\
\hline 276 & 9955 & -44.7 & 51 & 0.13 \\
\hline 250 & 10610 & -50.5 & 26 & 0.04 \\
\hline 225 & 11278 & -56.7 & 29 & 0.02 \\
\hline 200 & 12030 & -54.1 & 19 & 0.02 \\
\hline 177 & 12802 & -52.7 & 11 & 0.02 \\
\hline 150 & 13890 & -52.7 & 3 & 0.01 \\
\hline 124 & 15114 & -53.9 & 1 & 0.00 \\
\hline
\end{tabular}

Table 4-1. Selected data from atmospheric sounding taken on 26 June 2014 at Salem, Oregon (00Z sounding, NOAA station KSLE, WMO ident. 72694). Note that the air temperature remains relatively constant above 10610 meters altitude $(250 \mathrm{mBar})$, indicating the tropopause (upper limit of the troposphere).

first approximation, the similarities between the results of the trial experiment (Figure 41), which used ambient drying over the course of one to two days, and the bacteriophage T4 results using the final experimental design (Figure 4-2), which had the initial four hours of drying in a vacuum concentrator, suggest that any difference due to the more rapid initial drying was within an order of magnitude. Furthermore, the absolute humidity in the vacuum concentrator - assuming saturation - would have been $6.4 \mathrm{mg} / \mathrm{L}$, well above that in the vacuum desiccator $(0.005 \mathrm{mg} / \mathrm{L})$. 
Lyophilization is frequently used to dry cells and viruses (it is often referred to as "freeze-drying") while keeping them viable on rehydration. It involves rapid freezing to $50^{\circ} \mathrm{C}$ - to limit ice crystal formation, which can damage cells and virus particles - and reducing the atmospheric pressure to $50-300$ mtorr (70 - 400 microbar). Since thus frozen organisms are below the triple point of water $\left(0.1^{\circ} \mathrm{C}, 6.12 \mathrm{mbar}\right)$, water sublimates as water vapor. Rubella, varicella, Newcastle disease, smallpox and mumps vaccines are all viruses that can be and are routinely and commercially lyophilized and rehydrated as infectious "live" vaccines. However, the experimental conditions used here did not approximate lyophilization because the temperature was - even at its lowest in the vacuum concentrator - above the freezing point of water and the pressure was never lower than 13 mbar (see Methods).

Probably the most compelling argument against the hypothesis that the drying conditions were responsible for the drying tolerance of bacteriophage T4 and SSV-K after exposure to silica is the lack of drying tolerance in the untreated (not silica-exposed) control preparations. In addition, neither the control nor the silica-exposed bacteriophage PRD1 showed any drying tolerance, which suggests that the combination of silica exposure and the drying process was not itself sufficient to increase drying tolerance unless a silica coating was formed.

One of the hypotheses for virus dispersal, especially of hot spring viruses, is that they are aerosolized from the action of outgassing fumaroles in the hot springs (Snyder et al., 2007). So, how relevant are these drying data to the environmental drying experienced 
by a virus suspended in an aerosol droplet? Because the surface area of an aerosol is vastly larger than the surface are of the liquid in the experimental technique, drying would be more rapid in an aerosolized solution than in the bulk solution at the same ambient humidity.

Aerosol drying is widely used commercially and the process is fairly well characterized (Filková et al., 2006). A fundamental aspect of aerosol drying is the increase in vapor pressure over a liquid when the surface is curved; this is quantified by the Kelvin equation (Russell and Ming, 2002), which is shown below.

$$
\ln \frac{p_{i}}{p_{0}}=\frac{2 \sigma M}{R T \rho r}
$$

Kelvin equation; $p_{0}$ is the vapor pressure of the liquid over a flat surface, $p_{i}$ is the vapor pressure over the surface of the droplet, $R$ is the molar gas constant, $T$ is temperature in degrees Kelvin, $r$ is radius, $\rho$ is density of the droplet, $M$ is molar mass, $\sigma$ is surface tension.

From this equation, it is clear that pure liquids in small droplets, as in an aerosol, evaporate more rapidly than bulk liquid because their vapor pressure increases as the radius of the droplet decreases. Even if the ambient atmosphere is saturated with the vapor, liquid will still evaporate from aerosol droplets; as the droplets evaporate, their radius will decrease, further increasing the vapor pressure of the liquid in the droplets. The process stops only when the liquid completely evaporates or when the ambient vapor pressure reaches that of the droplet surface. Further complicating the process, larger 
droplets may potentially gain mass from deposition - if their surface vapor pressure is lower than the atmospheric vapor pressure - at the same time that smaller droplets are losing mass from evaporation.

For aerosols with dissolved solids, such as would result from aerosolization of hot spring water, the process is even more complicated. Bulk vapor pressure decreases with the addition of non-volatile solutes, such as silica, proportionate to the concentration of the solute; the concentration of the solute increases as the liquid solvent phase evaporates, decreasing the vapor pressure of the bulk solution as the decrease in radius increases the surface vapor pressure. In addition, some solutes have an affinity for water, through hydrogen bonding and other processes, which increases their effect on vapor pressure beyond what would be expected from colligative properties; silica is one of these solutes. As a result, the ultimate water concentration of an aerosol droplet from a hot spring depends on the ambient humidity, the solute concentration in the bulk water, the type of solutes in the bulk water and the size of the droplets produced in the aerosolization process (Filková et al., 2006).

Most of the literature on the water content of aerosol particles, as contrasted to the water content of the aerosol as a whole (particles and atmosphere), concerns spray drying, which is not particularly relevant to these experiments because spray drying typically involves suspending the aerosol in dehumidified air heated to near or above the boiling point of water. Studies of the water content of aerosol particles (e.g. Khlystrov et al., 2005) show that it varies directly with ambient humidity but is very sensitive to the 
nature of the solute(s); aerosols with more hygroscopic solutes have higher water contents. Typically, at a relative humidity below $20 \%$, the water content of ambient aerosol particles is less than $10 \%$ by weight (Khlstrov et al., 2005). Unfortunately, data on the water content of ambient aerosol particles at very low humidity appears to be lacking.

Aerosolized water from a silica-depositing hot spring would contain significant amounts of dissolved silica in solution (Ball et al., 2002; Janik and McLaren, 2010; McCleskey et al., 2004; White et al., 1956); as water evaporates from the aerosol droplets, the solution will cool and concentrate, at some point triggering deposition of amorphous silica, also known as opal-A (Orange et al., 2013). One characteristic of opal-A is that it has a variable but significant amount of bound water, ranging from $1 \%$ to $14 \%$ by weight (Day and Jones, 2008; Jones and Renaut, 2004); this water is more tightly bound than solvent water and would not evaporate as readily. If the virus particles are surrounded by opal-A, as suggested by TEM images (Figures 3-3 and 3-4), its bound water could retard drying of the enclosed virus in much the same way a damp paper towel can retard the drying of lettuce. The water content of the studied viruses is more difficult to assess, but studies of the DNA content of the bacteriophage T4 capsid (Purohit et al., 2005) and the water content of isolated bacteriophage T4 proteins (Krushelnitsky et al., 2006) suggest that the water content of bacteriophage T4 in physiological solution is between $55 \%$ and $50 \%$. Results shown here (Figures 4-1 and 4-2) indicate that silicification allows some viruses to persist for days to weeks under near-stratospheric pressure and humidity. It could allow global dispersal (Smith et al., 2010), potentially explaining some of the conflicting 
results of virus distribution (Angly et al., 2006; Breitbart et al., 2004a; Breitbart and Rohwer, 2005; Held and Whitaker, 2009; Short and Suttle, 2005). This is particularly true for silicified hot spring viruses that could be aerosolized by fumarole outgassing or dispersed by volcanic activity (Snyder et al., 2007). However, the rapidity of drying in the experimental methods used here would be greater than that which would be experienced in an aerosol unless it were somehow rapidly transported into the upper troposphere, an unlikely event except in a cataclysmic volcanic eruption. Since organisms are more likely to survive drying if it is done rapidly (Garcia, 2011), the rapid drying of the experimental method may have biased the results in favor of survival. Despite this, the control preparations without silicification showed no detectable virus infectivity, except in the case of VACV.

Previously published studies of virus drying tolerance have generally been performed in room air, with neither reduced atmospheric pressure nor desiccant used to accelerate drying (e.g. Ding et al., 2011; Fogarty et al., 2008; Nakano et al., 1998). In contrast, a number of studies of drying resistance of bacteria have utilized partial vacuum and/or desiccants; Bauermeister, et al (2010) showed that Deinococcus radiodurans could tolerate desiccation in ultra-high vacuum $\left(10^{-5}\right.$ Pascals $)$ for up to four weeks with minimal loss of viability, although it must be noted that $D$. radiodurans is extremely atypical in its desiccation tolerance. More typical would be the results of Singh et al (2013), which found a strain of Anabena which retained nearly $10 \%$ of its viability after 14 days exposure to a relative humidity of $<5 \%$ over fused calcium chloride or a study by Walsh and Camilli (2011), which found several strains of Streptococcus pneumonia that 90 
remained viable and infectious after up to 28 days of drying at ambient pressure and $18 \%$ to $45 \%$ relative humidity.

Bacteria have a variety of adaptations that allow some of them to tolerate a high degree of drying; some can tolerate drying to the point where water makes up only $2 \%$ of the cell by weight (Potts, 1994; Garcia, 2011). Some of the challenges of drying, from an organismal point of view, include protein denaturation, membrane disruption and DNA damage. Many bacteria use non-reducing sugars, such as trehalose and sucrose, to "substitute" for water, the hydroxyl groups of the sugars replacing the hydrogen bonding of water (Crowe, 2002; Jain and Roy, 2009). The substitution of trehalose or sucrose for water stabilizes the conformation of proteins as well as lipid membranes by interaction of the hydroxyl groups of the sugars with hydrogen-bonding sites on the proteins and lipids (Crowe, 2002). The numerous silanol groups of silica (Day and Jones, 2008) could potentially serve the same function (Coradin and Livage, 2001; Rimola et al., 2009), but this hypothesis has not yet been tested directly.

Manganese accumulation (as $\mathrm{Mn}^{2+}$ ) is also associated with resistance to drying, presumably by protecting the proteins and other macromolecules from oxidation (Fredrickson et al., 2008). Heat-shock proteins are also important in preventing the denaturation of proteins during drying (Garcia, 2005). Some exceptionally desiccation tolerant organisms have highly efficient DNA repair enzymes and contain multiple copies of their genome to allow rapid repair of single- and double-stranded DNA breaks that 
occur during desiccation (Bauermeister et al., 2010; Beblo et al., 2011; Singh et al., 2013; Zerulla and Soppa, 2014).

Many of these adaptations, such as manganese accumulation, are not available to viruses because they have no metabolic activity until they infect their host cell. Despite that, there are a number of viruses with notable tolerance to drying, such as VACV (Collier, 1954; Newman et al., 2003) and bacteriophage T1 (German et al., 2006). Both of these viruses can remain infectious years (bacteriophage T1) to decades (VACV) in a dry condition, but the mechanism behind this drying tolerance is yet unknown. Bacteriophage T1 is structurally similar to bacteriophage T4 and infects the same species (E. coli), but bacteriophage $\mathrm{T} 1$ can remain infectious for years in a dry state, while bacteriophage T4 as demonstrated in these experiments - does not.

In some ways, the bacterial spore may be a more relevant comparison to viruses than the drying resistant bacteria. Bacterial spores are more resistant to drying than their parent bacteria (Dose and Klein, 1996) through a variety of mechanisms, including thick cell walls that reduce water loss (Friedline et al., 2014). In addition, spores have DNA protective proteins, such as the small, acid-soluble spore proteins (SASPs) of Bacillus and Clostridium spores. These proteins bind to DNA and are known to be critical for desiccation resistance, but their exact function is still under investigation (Setlow, 1995; Leyva-Illades et al., 2007). Many viruses have nucleic acid binding proteins, some of which might potentially provide protection against genome damage during drying, but this has not yet been shown. 
The results from the virus drying experiments described here give a limited insight into the effect of silicification on the drying tolerance of a limited number of viruses. Future investigations should utilize a range of exposure humidity since even VACV, which has great innate drying tolerance, is not as stable when exposed to intermediate humidity levels (Wood et al., 2013). Using saturated salt solutions to maintain a range of stable, well-defined humidity could reveal the degree to which silica exposure increases drying tolerance and potentially giving insight into possible mechanisms. A detailed examination of silicified virus by proton nuclear magnetic resonance spectroscopy (Tian et al., 2014), electron paramagnetic resonance spectroscopy or Fourier transform infrared spectroscopy (Malferrari et al., 2014) could provide valuable information about not only water content but also the types of interactions between water and virus macromolecules. Finally, repeating these experiments using lyophilization as the drying method could show how silicification compares to this widely used technique.

These virus drying experiments have raised more questions than they have answered; further experimentation is necessary to further quantify the effect of silicification on drying resistance of viruses and to explore potential mechanisms, nonetheless they indicate that a silica treatment can confer enhanced drying resistance to some viruses. 


\section{Chapter 5: Conclusions.}

In the course of the experiments performed in the previous chapters, four hypotheses were tested and some intriguing findings emerged from the results. Those hypotheses were:

1. Viruses will become coated with silica on exposure to environmentally relevant concentrations of dissolved silica.

2. There will be a detectable and unique signature remaining after the viruses are coated with silica.

3. Coating viruses with silica will reduce their infectivity.

4. Different viruses will silicify to differing degrees, a reflection of variable surface characteristics, as manifested by differing impacts on infectivity.

\section{5-1: Viruses can silicify in some environmentally relevant concentrations of dissolved silica.}

The experiments described in Chapter 2 demonstrated that bacteriophage T4 could and did become coated with silica when exposed for 48 hours to concentrations of silica 
similar to those found in several terrestrial hot springs ( $300 \mathrm{ppm} / 5 \mathrm{mM})$. This was supported by TEM imaging, which showed an increased thickness of the virus particles after silica treatment (Figure 2-5). This was a layer of material which did not exclude uranyl acetate (used as a negative stain), suggesting that it is sufficiently porous to allow diffusion of a large (ionic radius $0.18 \mathrm{~nm}$ (Duff et al, 2002)) oxycation. EDX analysis of the treated virus particles showed that they had detectable levels of silicon, which was not found in untreated virus particles (Figure 2-9). This demonstrates that exposing bacteriophage T4 to environmentally relevant silica concentrations can cause those virus particles to become coated with a silicon-containing material - presumably silica - which opens the possibility that viruses as well as bacteria will silicify together in terrestrial hot springs and could be found together in fossil-bearing silicates from hydrothermal sources.

Still unknown is the nature of the silica interaction with the virus, although there are some clues that can be gleaned from the available data. Since the interior of the bacteriophage $\mathrm{T} 4$ capsid takes up the electron-dense uranyl acetate stain, even after silica exposure, the silica coating is porous enough for a relatively large cation to diffuse freely and, additionally, the interior of the capsid is not filled with silica. In Figure 2-5 (and Figures 2-6, 2-7 and 3-3), the interior of the capsid stains densely; if the interior of the capsid had been partially or completely filled by silica, less uranyl ion would have been able to enter the capsid and the silica-exposed capsids should stain lighter. This is not surprising, since the DNA is strongly negatively charged and would tend to repel the negatively charged silicate ions. 
The TEM images of silica-exposed SSV-K (Figure 3-4), on the other hand, are not so clear-cut. The unexposed SSV-K shows less uranyl staining than the unexposed bacteriophage T4 capsid. When SSV-K is exposed to silica concentrations of $300 \mathrm{ppm}$ and $600 \mathrm{ppm}$, the interior of the virus is qualitatively less stained by uranyl acetate as the concentration increases, suggesting that either the nature of the silica coating is different (i.e. less porous) or that the interior of the virus is filling with silica. These are questions that will need to be answered by future research.

Further experimentation (Chapter 3) revealed that silica concentrations below supersaturation - the point of homogenous nucleation - did not have a measurable effect on infectivity of the tested viruses. However, concentrations at or above $300 \mathrm{ppm}(5 \mathrm{mM})$ silica, above the point of homogenous nucleation(Carroll et al., 1998; Conrad et al., 2007), did decrease infectivity in bacteriophage T4, SSV-K and VACV, but not bacteriophage PRD1 and PBCV-1. Higher concentrations (600 ppm / $10 \mathrm{mM})$ were even more effective at decreasing the infectivity of bacteriophage T4, SSV-K and VACV (Figure 3-2), but had no measurable effect on bacteriophage PRD1 and PBCV-1. The viruses affected by silica exposure also varied in the degree to which their infectivity was reduced, with bacteriophage $\mathrm{T} 4$ and VACV showing very similar reductions, despite very different size and structure, and SSV-K, a virus found in hot springs (Wiedenheft et al., 2004), being significantly less affected. These findings are particularly significant, since a silica concentration of $600 \mathrm{ppm}(10 \mathrm{mM})$ is well above the point of supersaturation at room temperature (Carroll et al., 1998; Conrad et al., 2007), suggesting that 
bacteriophage PRD1 and PBCV-1 in some way resisted the deposition of silica on their surfaces - or, at least, the surface structures critical for infectivity.

As was discussed in Chapter 2, the radius of a particle has a strong influence on the ability of silica, or other solutes, to precipitate on its surface. The radii of the capsids of the tested viruses vary widely: bacteriophage PRD1 has a capsid radius of $33 \mathrm{~nm}$ (Bamford et al., 1995), PBCV-1 has a capsid radius of $95 \mathrm{~nm}$ (Thiel et al., 2010), bacteriophage T4 has a prolate capsid with a major radius of $55 \mathrm{~nm}$ (Karam, 1994; Leiman et al., 2003), the capsid of SSV-K is a prolate spheroid (spindle) with a major radius of $40 \mathrm{~nm}$ (Rice et al., 2001) and VACV is a large ellipsoid enveloped virus with a major radius of $180 \mathrm{~nm}$ and a minor radius of $125 \mathrm{~nm}$ (Resch et al., 2007). The viruses most affected by silica exposure were bacteriophage T4 (major radius $55 \mathrm{~nm}$ ) and VACV (major radius $180 \mathrm{~nm}$ ); SSV-K (major radius $40 \mathrm{~nm}$ ) was intermediate and both bacteriophage PRD1 (major radius $33 \mathrm{~nm}$ ) and PBCV-1 (major radius $95 \mathrm{~nm}$ ) showed no evidence of silicification, suggesting that silicification of these viruses was not determined by their radius alone.

The surface features of these viruses are also different, although not all of them have been thoroughly characterized. Of the four, only VACV has an external lipid membrane (Carrascosa et al., 2009; Dubochet et al., 1994; Smith et al., 2002), although PRD1 has an internal lipid membrane (Bamford et al., 1995; Cockburn et al., 2004; Laurinavicius et al., 2007). Thus, the surface of VACV will be a combination of phospholipids and embedded proteins. The surface other three viruses have protein surfaces, so interactions 
with silica will be determined by the type of amino acid functional groups exposed on the surface. The structure of bacteriophage T4 is the most completely known (Aksyuk et al., 2009; Fokine et al., 2004; Fokine et al., 2013; Leiman et al., 2004; Leiman et al., 2003); there is also a $4 \AA$ resolution X-ray crystallographic structure for bacteriophage PRD1 (Cockburn et al., 2004). For these viruses, computer modeling could potentially reveal any significant differences in the amino acid residues exposed on their surfaces. For PBCV-1, there is a $9.5 \AA$ A cryoelectron microscopy structure for PBCV-1 (Zhang et al., 2011) which, in concert with X-ray crystallographic structures for the individual surface proteins, could also provide a detailed model of the surface of the virus. The VACV virion, unfortunately, has apparently only had low-resolution ( 25 - $45 \AA$ A) cryoelectron imaging and performed to date (Carrascosa et al., 2009; Chichon et al., 2009; Dubochet et al., 1994; Roos et al., 1996), so it would be more difficult to accurately characterize the surface amino acid functional groups.

These findings indicate that viruses do not act simply as passive nucleation centers for silica and that they have individual differences, most likely surface characteristics, which strongly influence the precipitation of silica on their surfaces.

\section{5-2: Silicified viruses will have some recognizable and detectable signature.}

Examination of both environmental and synthetic silica sinter by fluorescence microscopy after nucleic acid staining with acridine orange showed that it was possible to 
visualize microorganisms including viruses in sinter, but the diffusion of light by the silica obscured the distinctive point fluorescence of virus particles (Wen et al., 2004), making them indistinguishable from small bacteria. The artificial sinter experiments were designed to maximize the likelihood of success by using a higher concentration of virus than would be expected in the environment (Breitbart et al., 2004; Filippini et al., 2008; He et al., 2009; Lymer et al., 2008; Personnic et al., 2009; Weinbauer, 2004; Wommack and Colwell, 2000) and eliminating the debris and detritus that would be found in a natural system. Epifluorescence microscopy using fluorescent nucleic acid stain, like acridine orange, is a technique routinely used to enumerate viruses in soil and water. As a result, the failure to distinguish viruses from other microbes under these conditions suggests that the same techniques are unlikely to succeed in either modern or ancient environmental sinters. It is possible that embedding the sinter in a non-fluorescent matrix and examining thin sections would allow clearer and more distinctive images.

TEM examination of viruses as they are being silicified under the conditions in Chapter 2 showed that they can be recognized early in the process (Figures 2-5 and 2-6), but within a few days the silica accumulation begins to obscure the viral morphology (Figure 2-7). It is possible that a refinement of sample preparation and staining could improve the ability to recognize viruses embedded in a silica matrix, but it may be difficult to unambiguously differentiate between embedded viruses and cellular fragments.

Elemental analysis of silicified bacteriophage T4 by EDX (Chapter 2) revealed that, in addition to a strong silicon signature which was not seen in viruses that were not exposed 99 
to silica, there was a readily detectable signal of phosphorus (Figure 2-9). Unfortunately, the same phosphorus signal was seen when the host cell membrane was analyzed (not shown), which would mean that EDX would not be able to discriminate between virus particles and fragments of the host cell membrane in fossil deposits from ancient hot springs. If the fossilization processes sufficiently distorted the virus particle to render its morphology unrecognizable by electron microscopy, elemental analysis would not be able to distinguish between a virus and cellular debris. The processes of diagenesis in amorphous silica involve compaction and crystallization of the silica matrix accompanied by a dramatic reduction in porosity and water content (Herdianita et al., 2000; Jones and Renaut, 2007; Lynne and Campbell, 2003; Lynne and Campbell, 2004). Even though the initial stages of silica diagenesis, the compaction of opal-A, is largely the result of dissolution and reprecipitation of silica (Herdianita et al., 2000; Jones and Renaut, 2007), if the integrity of the viral capsid has been compromised by hydrolysis of the proteins or reduction of disulfide bonds, for example, the structure of the virus will be lost when the surrounding silica matrix is remodeled. In later stages, when opal-A transforms to opal-C or opal-C over the course of $100-10,000$ years after initial deposition (depending on conditions), crystal formation causes displacements of tens to hundreds of nanometers (Day and Jones, 2008; Herdianita et al., 2000; Jones and Renaut, 2003; Jones and Renaut, 2007; Lynne and Campbell, 2003; Lynne and Campbell, 2004; Lynne et al., 2005); while this amount of deformation would not necessarily render bacterial microfossils unrecognizable, it would completely obliterate most viruses. As a result, it is unlikely that morphologically recognizable virus could be found in sinters more than 10,000 years old. 
Although there may be some detectable biosignatures of viruses, such as phosphorus, lipids or nucleic acids, in the fossil record, it would be extremely difficult to definitively identify them as belonging to viruses rather than fragments of cellular organisms. Even if the lipids were not degraded, viral lipids are derived from their hosts (e.g. Veit et al., 1996) and so could not readily be distinguished from cellular debris.

\section{5-3: Silicification of viruses will impact their infectivity / Viruses will differ in the degree of silicification or in the impact that silicification has on their infectivity.}

As shown in Chapter 3, silica treatment of bacteriophage T4, SSV-K and VACV dramatically reduced the infectivity of those viruses, with bacteriophage T4 and VACV being more sensitive than SSV-K (Figure 3-2). The fact that this effect was reversible shows that the loss of infectivity was most likely due to physical coating of critical structures of the viruses and not the result of a chemical change to the virus by silica treatment. The fact that the infectivity did not recover completely suggests that some of the viruses - up to $90 \%$ for VACV - were damaged by the process, as supported by Figures 3-6 and 3-7. Different viruses had markedly different responses to silica exposure (Figure 3-2), with two viruses - bacteriophage PRD1 and PBCV-1 - showing no discernible reduction of infectivity at any silica concentration tested.

Silica exposure had the unexpected effect of protecting some of the treated viruses from inactivation by drying. This protection appeared to vary directly with the magnitude of the decrease of infectivity during silica exposure (Figures 3-2 and 4-2). Silicified 
bacteriophage T4 showed a greater degree of protection than did SSV-K, which showed a lesser decline of infectivity during silica exposure; VACV did not show increased resistance to drying after silica exposure, but any increase in drying resistance may have been swamped by the innately high desiccation resistance of this virus (Collier, 1954). Bacteriophage PRD1 had no detectable resistance to drying and also did not show a decrease of infectivity with silica exposure, which was taken to indicate that was not silicified.

The drying tolerance of silicified bacteriophage T4 and SSV-K was done at an atmospheric pressure and humidity similar to that found at an altitude of over 10,000 meters (Chapter 4). At this altitude, which is routinely reached by volcanic ash during eruptions (Zaksek et al., 2013), there are strong winds - west to east in the Northern Hemisphere; east to west in the Southern Hemisphere - that routinely reach 150 knots and are generally in excess of 50 knots (Strong and Davis, 2008). At this velocity, silicified viruses could travel the 3500 nautical miles from Kamchatka's Uzon Caldera to the hot springs of Yellowstone National Park in one to three days. This mode of transportation could help explain the marked genetic similarities between hyperthermophilic viruses found in these and other widely separated locations (Snyder et al., 2007).

Although it was not possible to determine the exact nature of the interaction between the silica coating and the virus capsid or envelope, the fact that an extended period of drying progressively reduced the infectivity (Figure 4-2) strongly suggests that the silica coating 102 
is not forming a hermetic seal around the virus but is more probably holding some water by its own hydrogen bonding and greatly delaying the loss of surface bound water from the virion, similar to what is seen with trehalose and other sugars (Crowe, 2002; Hackel et al., 2012; Jain and Roy, 2009). Once that water is depleted, the surface proteins and lipid membranes (if present) will be disrupted or denatured (Dupont et al., 2011; Hedoux et al., 2012; Prestrelski et al., 1993).

\section{5-4: Future directions.}

As often is the case, this research has raised almost as many questions as it answered. Future areas of investigation I hope to pursue include the thermal stability of silicified viruses. This would further quantify the protective characteristics of silicification. Additionally, I hope to investigate the ability of the silica coating to mask viral surface proteins from circulating antibodies of mammalian adaptive immune systems. This may have significance in both the efficacy of silicified vaccines as well as their effect on the immune system. 


\section{Cited references:}

\section{Abuillan, W., Vorobiev, A., Hartel, A., Jones, N. G., Engstler, M. and}

Tanaka, M. (2012). Quantitative determination of the lateral density and intermolecular correlation between proteins anchored on the membrane surfaces using grazing incidence small-angle X-ray scattering and grazing incidence X-ray fluorescence. Journal of Chemical Physics 137, 8.

\section{Aksyuk, A. A., Leiman, P. G., Kurochkina, L. P., Shneider, M. M.,} Kostyuchenko, V. A., Mesyanzhinov, V. V. and Rossmann, M. G. (2009). The tail sheath structure of bacteriophage T4: a molecular machine for infecting bacteria. EMBO Journal 28, 821-829.

Al-Hanbali, H. S. and Holm, N. G. (2002). Evidence for fossilized subsurface microbial communities at the TAG hydrothermal mound. Geomicrobiology Journal 19, 429-438.

Alexander, G. B. (1954). The polymerization of monosilicic acid. Journal of the American Chemical Society. 76, 2094-2096.

Alexander, G. B. (1957). The effect of particle size on the solubility of amorphous silica in water. The Journal of Physical Chemistry 61, 1563-1564.

Altermann, W. and Schopf, J. W. (1995). Microfossils from the Neoarchean Campbell Group, Griqualand West Sequence of the Transvaal Supergroup, and their paleoenvironmental and evolutionary implications. Precambrian Research 75, 65-90. 
Álvaro, J. J. and Clausen, S. (2010). Morphology and ultrastructure of epilithic versus cryptic, microbial growth in lower Cambrian phosphorites from the Montagne Noire, France. Geobiology 8, 89-100.

Agol, V. I. (2010). Which Came First, the Virus or the Cell? Paleontological Journal 44, 728-736.

Aksyuk, A. A., Leiman, P. G., Kurochkina, L. P., Shneider, M. M., Kostyuchenko, V. A., Mesyanzhinov, V. V. and Rossmann, M. G. (2009). The tail sheath structure of bacteriophage T4: a molecular machine for infecting bacteria. $E M B O$ Journal 28, 821-829.

Amores, D. R. and Warren, L. A. (2007). Identifying when microbes biosilicify: The interconnected requirements of acidic $\mathrm{pH}$, colloidal $\mathrm{SiO}_{2}$ and exposed microbial surface. Chemical Geology 240, 298-312.

Anderson, T. R. and Fairley, J. P. (2008). Relating permeability to the structural setting of a fault-controlled hydrothermal system in southeast Oregon, USA. Journal of Geophysical Research-Solid Earth 113, 13.

Angly, F. E., Felts, B., Breitbart, M., Salamon, P., Edwards, R. A., Carlson, C., Chan, A. M., Haynes, M., Kelley, S., Liu, H. et al. (2006). The marine viromes of four oceanic regions. PLoS Biology 4, 2121-2131.

Asada, R. and Tazaki, K. (2001). Silica biomineralization of unicellular microbes under strongly acidic conditions. Canadian Mineralogist 39, 1-16.

Azaroual, M., Fouillac, C. and Matray, J. M. (1997). Solubility of silica polymorphs in electrolyte solutions .1. Activity coefficient of aqueous silica from 25 degrees to 250 degrees C, Pitzer's parameterisation. Chemical Geology 140, 155-165. 


\section{Ball, J. W., McCleskey, R. B., Nordstrom, D. K., Holloway, J. M. and}

Verplanck, P. L. (2002). Water-chemistry data for selected springs, geysers, and streams in Yellowstone National Park, Wyoming, 1999-2000, Boulder, Colorado: U.S. Geological Survey.

Bamford, D. H., Caldentey, J. and Bamford, J. K. H. (1995). Bacteriophage PRD1 - a broad-host-range dsDNA Tectivirus with an internal membrane. Advances in Virus Research, 45, 281-319.

Bamford, D. H., Palva, E. T. and Lounatmaa, K. (1976). Ultrastructure and life cycle of the lipid-containing bacteriophage Phi-6. Journal of General Virology 32, 249259.

Barghoorn, E. and Tyler, S. (1965). Microorganisms from the Gunflint chert. Science 147, 563-577.

Bauermeister, A., Moeller, R., Reitz, G., Sommer, S. and Rettberg, P. (2010). Effect of relative humidity on Deinococcus radiodurans' resistance to prolonged desiccation, heat, ionizing, germicidal, and environmentally relevant UV radiation. Microbial Ecology 61, 715-722.

Baumgartner, M., Stetter, K. O. and Foissner, W. (2002). Morphological, small subunit rRNA, and physiological characterization of Trimyema minutum (Kahl, 1931), an anaerobic ciliate from submarine hydrothermal vents growing from 28 degrees C to 52 degrees C. Journal of Eukaryotic Microbiology 49, 227-238.

Baumgartner, M., Yapi, A., Grobner-Ferreira, R. and Stetter, K. O. (2003). Cultivation and properties of Echinamoeba thermarum n. sp., an extremely thermophilic amoeba thriving in hot springs. Extremophiles 7, 267-274. 
Bearden, J. A. (1967). X-ray wavelengths. Reviews of Modern Physics 39, 78.

Beblo, K., Douki, T., Schmalz, G., Rachel, R., Wirth, R., Huber, H., Reitz, G. and Rettberg, P. (2011). Survival of thermophilic and hyperthermophilic microorganisms after exposure to UV-C, ionizing radiation and desiccation. Archives of Microbiology 193, 797-809.

Bechtel, A., Jia, J. L., Strobl, S. A. I., Sachsenhofer, R. F., Liu, Z. J., Gratzer, R. and Puttmann, W. (2012). Palaeoenvironmental conditions during deposition of the Upper Cretaceous oil shale sequences in the Songliao Basin (NE China): Implications from geochemical analysis. Organic Geochemistry 46, 76-95.

Benning, L. G., Phoenix, V. R., Yee, N. and Konhauser, K. O. (2004a). The dynamics of cyanobacterial silicification: An infrared micro-spectroscopic investigation. Geochimica et Cosmochimica Acta 68, 743-757.

Benning, L. G., Phoenix, V. R., Yee, N. and Tobin, M. J. (2004b). Molecular characterization of cyanobacterial silicification using synchrotron infrared microspectroscopy. Geochimica et Cosmochimica Acta 68, 729-741.

Benson, S. D., Bamford, J. K. H., Bamford, D. H. and Burnett, R. M. (2004). Does common architecture reveal a viral lineage spanning all three domains of life? Molecular Cell 16, 673-685.

Bernado, P. and Svergun, D. I. (2012). Structural analysis of intrinsically disordered proteins by small-angle X-ray scattering. Molecular Biosystems 8, 151-167.

Bertani, G. (1951). Studies on lysogenesis I.: The mode of phage liberation by lysogenic Escherichia coli. Journal of Bacteriology 62, 293-300. 
Beumer, A. and Robinson, J. B. (2005). A broad-host-range, generalized transducing phage (SN-T) acquires 16S rRNA genes from different genera of bacteria. Applied and Environmental Microbiology 71, 8301-8304.

Bouvier, T. and del Giorgio, P. A. (2007). Key role of selective viral-induced mortality in determining marine bacterial community composition. Environmental Microbiology 9, 287-297.

Bower, J. H. (1934). Comparative efficiencies of various dehydrating agents used for drying gases (a survey of commercial drying agents). Bureau of Standards Journal of Research 12, 241-248.

Brasier, M. D., Green, O. R., Lindsay, J. F., McLoughlin, N., Steele, A. and Stoakes, C. (2005). Critical testing of earth's oldest putative fossil assemblage from the similar to 3.5 Ga Apex Chert, Chinaman Creek, Western Australia. Precambrian Research 140, 55-102.

Breitbart, M., Miyake, J. H. and Rohwer, F. (2004a). Global distribution of nearly identical phage-encoded DNA sequences. FEMS Microbiology Letters 236, 249256.

Breitbart, M. and Rohwer, F. (2005). Here a virus, there a virus, everywhere the same virus? Trends in Microbiology 13, 278-284.

Breitbart, M., Wegley, L., Leeds, S., Schoenfeld, T. and Rohwer, F. (2004b). Phage community dynamics in hot springs. Applied and Environmental Microbiology 70, $1633-1640$. 
Brocks, J. J., Buick, R., Summons, R. E. and Logan, G. A. (2003). A

reconstruction of Archean biological diversity based on molecular fossils from the 2.78 to 2.45 billion-year-old Mount Bruce Supergroup, Hamersley Basin, Western Australia. Geochimica et Cosmochimica Acta 67, 4321-4335.

Brocks, J. J., Logan, G. A., Buick, R. and Summons, R. E. (1999). Archean molecular fossils and the early rise of eukaryotes. Science 285, 1033-1036.

Brown, P. B. and Wolfe, G. V. (2006). Protist genetic diversity in the acidic hydrothermal environments of Lassen Volcanic National Park, USA. Journal of Eukaryotic Microbiology 53, 420-431.

Busey, R. H. and Mesmer, R. E. (1977). Ionization equilibriums of silicic acid and polysilicate formation in aqueous sodium chloride solutions to 300 degree.C. Inorganic Chemistry. 16, 2444-2450.

Cady, S. L. and Farmer, J. D. (1996). Fossilization processes in siliceous thermal springs: Trends in preservation along thermal gradients. In Evolution of Hydrothermal Ecosystems on Earth, vol. 202, pp. 150-173. Chichester: John Wiley \& Sons Ltd.

Carlson, K. (2005). Working with Bacteriophages: Common Techniques and Methodological Approaches. In Bacteriophages: Biology and Applications, (eds. E. Kutter and A. Sulakvelidze), pp. 425-484. Boca Raton, FL: CRC Press.

Carrado, K. A., Xu, L., Gregory, D. M., Song, K., Seifert, S. and Botto, R. E. (2000). Crystallization of a layered silicate clay as monitored by small-angle X-ray scattering and NMR. Chemistry of Materials 12, 3052-3059. 
Carrascosa, J. L., Chichon, F. J., Pereiro, E., Rodriguez, M. J., Fernandez, J.

J., Esteban, M., Heim, S., Guttmann, P. and Schneider, G. (2009). Cryo-X-ray

tomography of vaccinia virus membranes and inner compartments. Journal of Structural Biology 168, 234-239.

Carroll, M. W. and Moss, B. (1997). Host range and cytopathogenicity of the highly attenuated MVA strain of Vaccinia virus: Propagation and generation of recombinant viruses in a nonhuman mammalian cell line. Virology 238, 198-211.

Carroll, S., Mroczek, E., Alai, M. and Ebert, M. (1998). Amorphous silica precipitation (60 to 120 degrees C): Comparison of laboratory and field rates. Geochimica et Cosmochimica Acta 62, 1379-1396.

Chan, S. H. (1989). A review on solubility and polymerization of silica. Geothermics 18, 49-56.

Channing, A. and Butler, I. B. (2007). Cryogenic opal-A deposition from Yellowstone hot springs. Earth and Planetary Science Letters 257, 121-131.

Chen, C. T. A. and Marshall, W. L. (1982). Amorphous silica solubilities 4: Behavior in pure water and aqueous sodium chloride, sodium sulfate, magnesium chloride and magnesium sulfate solutions up to 350 degrees C. Geochimica et Cosmochimica Acta 46, 279-287.

Chichon, F. J., Rodriguez, M. J., Risco, C., Fraile-Ramos, A., Fernandez, J. J., Esteban, M. and Carrascosa, J. L. (2009). Membrane remodelling during vaccinia virus morphogenesis. Biology of the Cell 101, 401-414.

Childs, J. D. and Birnboim, H. C. (1975). Polyacrylamide gel electrophoresis of intact bacteriophage T4D particles. Journal of Virology 16, 652-661. 
Cloud, P. E., Jr. (1965). Significance of the Gunflint (Precambrian) microflora: Photosynthetic oxygen may have had important local effects before becoming a major atmospheric gas. Science 148, 27-35.

Cloud, P. E. and Licari, G. R. (1968). Microbiotas of the Banded Iron Formations. Proceedings of the National Academy of Sciences of the United States of America 61, 779-786.

Cockburn, J. J. B., Abrescia, N. G. A., Grimes, J. M., Sutton, G. C., Diprose, J. M., Benevides, J. M., Thomas, G. J., Bamford, J. K. H., Bamford, D. H. and Stuart, D. I. (2004). Membrane structure and interactions with protein and DNA in bacteriophage PRD1. Nature 432, 122-125.

Collier, L. (1954). The preservation of vaccinia virus. Bacteriology Review 18, $74-86$.

Conrad, C. F., Icopini, G. A., Yasuhara, H., Bandstra, J. Z., Brantley, S. L. and Heaney, P. J. (2007). Modeling the kinetics of silica nanocolloid formation and precipitation in geologically relevant aqueous solutions. Geochimica et Cosmochimica Acta 71, 531-542.

Contursi, P., Jensen, S., Aucelli, T., Rossi, M., Bartolucci, S. and She, Q. X. (2006). Characterization of the Sulfolobus host-SSV2 virus interaction. Extremophiles 10, 615-627.

Coradin, T., Durupthy, O. and Livage, J. (2002). Interactions of aminocontaining peptides with sodium silicate and colloidal silica: A biomimetic approach of silicification. Langmuir 18, 2331-2336. 
Coradin, T. and Livage, J. (2001). Effect of some amino acids and peptides on silicic acid polymerization. Colloids and Surfaces B - Biointerfaces 21, 329-336.

Coradin, T. and Lopez, P. J. (2003). Biogenic silica patterning: Simple chemistry or subtle biology? ChemBioChem 4, 251-259.

Cox, J. S., Smith, D. S., Warren, L. A. and Ferris, F. G. (1999). Characterizing heterogeneous bacterial surface functional groups using discrete affinity spectra for proton binding. Environmental Science \& Technology 33, 4514-4521.

Crowe, L. M. (2002). Lessons from nature: the role of sugars in anhydrobiosis. Comparative Biochemistry and Physiology A - Molecular and Integrative Physiology 131, 505-513.

Davidsohn, I. and Henry, J. B. (1974). Hematology. In Clinical Diagnosis by Laboratory Methods, eds. I. Davidsohn and J. B. Henry), pp. 135-137. Philadelphia, PA: W.B. Saunders.

Day, R. and Jones, B. (2008). Variations in water content in opal-A and opal-CT from geyser discharge aprons. Journal of Sedimentary Research 78, 301-315.

de Araujo, M. F. F. and Godinho, M. J. L. (2009). Short-term variations of virus-like particles in a tropical lake: Relationship with microbial communities (bacteria, ciliates and flagellates). Microbiological Research 164, 411-419.

Dickerson, M. B., Sandhage, K. H. and Naik, R. R. (2008). Protein- and peptide-directed syntheses of inorganic materials. Chemical Reviews 108, 4935-4978.

Diemer, G. S. and Stedman, K. M. (2012). A novel virus genome discovered in an extreme environment suggests recombination between unrelated groups of RNA and DNA viruses. Biology Direct 7, 14. 
Ding, D. C., Chang, Y. C., Liu, H. W. and Chu, T. Y. (2011). Long-term persistence of human papillomavirus in environments. Gynecologic Oncology 121, 148151.

Doi, K., Fujino, Y., Inagaki, F., Kawatsu, R., Tahara, M., Ohshima, T., Okaue, Y., Yokoyama, T., Iwai, S. and Ogata, S. (2009). Stimulation of expression of a silica-induced protein (Sip) in Thermus thermophilus by supersaturated silicic acid. Applied and Environmental Microbiology 75, 2406-2413.

Dose, K. and Klein, A. (1996). Response of Bacillus subtilis spores to dehydration and UV irradiation at extremely low temperatures. Origins of Life and Evolution of the Biosphere 26, 47-59.

Dove, P. M. and Nix, C. J. (1997). The influence of the alkaline earth cations, magnesium, calcium, and barium on the dissolution kinetics of quartz. Geochimica et Cosmochimica Acta 61, 3329-3340.

Dowd, S. E., Pillai, S. D., Wang, S. Y. and Corapcioglu, M. Y. (1998). Delineating the specific influence of virus isoelectric point and size on virus adsorption and transport through sandy soils. Applied and Environmental Microbiology 64, 405-410.

Doyle, R. J., Matthews, T. H. and Streips, U. N. (1980). Chemical basis for selectivity of metal ions by the Bacillus subtilis cell wall. Journal of Bacteriology 143, 471-480.

Dubochet, J., Adrian, M., Richter, K., Garces, J. and Wittek, R. (1994). Structure of intracellular mature Vaccinia virus observed by cryoelectron microscopy. Journal of Virology 68, 1935-1941. 
Duff, M. C., Coughlin, J. U. and Hunter, D. B. (2002). Uranium coprecipitation with iron oxide minerals. Geochimica et Cosmochimica Acta 66, 35333547.

Dupont, S., Beney, L., Ferreira, T. and Gervais, P. (2011). Nature of sterols affects plasma membrane behavior and yeast survival during dehydration. Biochimica et Biophysica Acta - Biomembranes 1808, 1520-1528.

Ehlers, E. G., Stiles, D. V. and Birle, J. D. (1965). Fossil bacteria in pyrite. Science 148, 1719-1721.

Fang, Y., Poulsen, N., Dickerson, M. B., Cai, Y., Jones, S. E., Naik, R. R., Kroger, N. and Sandhage, K. H. (2008). Identification of peptides capable of inducing the formation of titania but not silica via a subtractive bacteriophage display approach. Journal of Materials Chemistry 18, 3871-3875.

Fanning, K. A. and Pilson, M. E. Q. (1973). On the spectrophotometric determination of dissolved silica in natural waters. Analytical Chemistry 45, 136-140.

Fein, J. B., Daughney, C. J., Yee, N. and Davis, T. A. (1997). A chemical equilibrium model for metal adsorption onto bacterial surfaces. Geochimica et Cosmochimica Acta 61, 3319-3328.

Fein, J. B., Scott, S. and Rivera, N. (2002). The effect of Fe on Si adsorption by Bacillus subtilis cell walls: insights into non-metabolic bacterial precipitation of silicate minerals. Chemical Geology 182, 265-273.

Ferris, F. G., Fyfe, W. S. and Beveridge, T. J. (1988). Metallic ion binding by Bacillus subtilis: Implications for the fossilization of microorganisms. Geology 16, 149152. 
Feschotte, C. and Gilbert, C. (2012). Endogenous viruses: insights into viral evolution and impact on host biology. Nature Reviews Genetics 13, 283-U88.

Filee, J., Forterre, P., Sen-Lin, T. and Laurent, J. (2002). Evolution of DNA polymerase families: Evidences for multiple gene exchange between cellular and viral proteins. Journal of Molecular Evolution 54, 763-773.

Filee, J., Tetart, F., Suttle, C. A. and Krisch, H. M. (2005). Marine T4-type bacteriophages, a ubiquitous component of the dark matter of the biosphere. Proceedings of the National Academy of Sciences of the United States of America 102, 12471-12476.

Filippini, M., Buesing, N. and Gessner, M. O. (2008). Temporal dynamics of freshwater bacterio- and virioplankton along a littoral-pelagic gradient. Freshwater Biology 53, 1114-1125.

Filková, I., Huang, L. X. and Mujumdar, A. S. (2006). Industrial Spray Drying Systems. In Handbook of Industrial Drying, (ed. A. S. Majumdar), pp. 215-256. Boca Raton, Florida: CRC Press.

Fishman, M. J. and Friedman, L. C. (1989). Methods for determination of inorganic substances in water and fluvial sediments. Denver, CO: US Geological Survey.

Fogarty, R., Halpin, K., Hyatt, A. D., Daszak, P. and Mungall, B. A. (2008). Henipavirus susceptibility to environmental variables. Virus Research 132, 140-144.

Fokine, A., Chipman, P. R., Leiman, P. G., Mesyanzhinov, V. V., Rao, V. B. and Rossmann, M. G. (2004). Molecular architecture of the prolate head of bacteriophage T4. Proceedings of the National Academy of Sciences of the United States of America 101, 6003-6008. 
Fokine, A., Zhang, Z. H., Kanamaru, S., Bowman, V. D., Aksyuk, A. A., Arisaka, F., Rao, V. B. and Rossmann, M. G. (2013). The molecular architecture of the bacteriophage T4 neck. Journal of Molecular Biology 425, 1731-1744.

Forterre, P. (2006a). The origin of viruses and their possible roles in major evolutionary transitions. Virus Research 117, 5-16.

Forterre, P. (2006b). Three RNA cells for ribosomal lineages and three DNA viruses to replicate their genomes: A hypothesis for the origin of cellular domain. Proceedings of the National Academy of Sciences of the United States of America 103, 3669-3674.

Forterre, P. (2011). Manipulation of cellular syntheses and the nature of viruses: The virocell concept. Comptes Rendus Chimie 14, 392-399.

Fredrickson, J. K., Li, S. M. W., Gaidamakova, E. K., Matrosova, V. Y., Zhai, M., Sulloway, H. M., Scholten, J. C., Brown, M. G., Balkwill, D. L. and Daly, M. J. (2008). Protein oxidation: key to bacterial desiccation resistance? ISME Journal 2, 393-403.

Friedline, A. W., Zachariah, M. M., Johnson, K., Thomas, K. J., Middaugh, A. N., Garimella, R., Powell, D. R., Vaishampayan, P. A. and Rice, C. V. (2014). Water Behavior in Bacterial Spores by Deuterium NMR Spectroscopy. Journal of Physical Chemistry B 118, 8945-8955.

Fuhrman, J. A. (1999). Marine viruses and their biogeochemical and ecological effects. Nature 399, 541-548.

Fuhrman, J. A. and Schwalbach, M. (2003). Viral influence on aquatic bacterial communities. Biological Bulletin 204, 192-195. 
Furukawa, Y. and O'Reilly, S. E. (2007). Rapid precipitation of amorphous silica in experimental systems with nontronite (NAu-1) and Shewanella oneidensis MR1. Geochimica et Cosmochimica Acta 71, 363-377.

Garcia, A. H. (2011). Anhydrobiosis in bacteria: From physiology to applications. Journal of Biosciences 36, 939-950.

\section{Garcia-Ruiz, J. M., Hyde, S. T., Carnerup, A. M., Christy, A. G., Van}

Kranendonk, M. J. and Welham, N. J. (2003). Self-assembled silica-carbonate structures and detection of ancient microfossils. Science 302, 1194-1197.

Geptner, A. R., Ivanovskaya, T. A. and Pokrovskaya, E. V. (2005). Hydrothermal fossilization of microorganisms at the earth's surface in iceland. Lithology and Mineral Resources 40, 505-520.

German, G. J., Misra, R. and Kropinksy, A. (2006). The T1-like Bacteriophages. In The Bacteriophages, $2^{\text {nd }}$ edition, (ed. R. Calendar and S.T.B Abedon), pp. 211-224. New York: Oxford University Press.

Golais, F., Holly, J. and Vitkovska, J. (2012). Coevolution of bacteria and their viruses. Folia Microbiologica 58, 177-186.

Griffin, J. L. (1972). Temperature tolerance of pathogenic and nonpathogenic free-living amoebas. Science 178, 869-70.

Guidry, S. A. and Chafetz, H. S. (2003). Anatomy of siliceous hot springs: examples from Yellowstone National Park, Wyoming, USA. Sedimentary Geology 157, 71-106. 


\section{Hackel, C., Zinkevich, T., Belton, P., Achilles, A., Reichert, D. and}

Krushelnitsky, A. (2012). The trehalose coating effect on the internal protein dynamics. Physical Chemistry Chemical Physics 14, 2727-2734.

Haile, J., Froese, D. G., MacPhee, R. D. E., Roberts, R. G., Arnold, L. J.,

Reyes, A. V., Rasmussen, M., Nielsen, R., Brook, B. W., Robinson, S. et al. (2009).

Ancient DNA reveals late survival of mammoth and horse in interior Alaska.

Proceedings of the National Academy of Sciences of the United States of America 106, $22352-22357$.

Hall, S. M. and Veizer, J. N. (1996). Geochemistry of Precambrian carbonates: VII. Belt supergroup, Montana and Idaho, USA. Geochimica et Cosmochimica Acta 60, 667-677.

He, L., Yin, K. D., Yuan, X. C., Li, D. M., Zhang, D. R. and Harrison, P. J. (2009). Spatial distribution of viruses, bacteria and chlorophyll in the northern South China Sea. Aquatic Microbial Ecology 54, 153-162.

Hedoux, A., Paccou, L., Achir, S. and Guinet, Y. (2012). In Situ Monitoring of Proteins During Lyophilization Using Micro-Raman Spectroscopy: A Description of Structural Changes Induced by Dehydration. Journal of Pharmaceutical Sciences 101, $2316-2326$.

Held, N. L. and Whitaker, R. J. (2009). Viral biogeography revealed by signatures in Sulfolobus islandicus genomes. Environmental Microbiology 11, 457-466.

Helton, R. R., Wang, K., Kan, J. J., Powell, D. H. and Wommack, K. E. (2012). Interannual dynamics of viriobenthos abundance and morphological diversity in Chesapeake Bay sediments. FEMS Microbiology Ecology 79, 474-486. 
Hendrix, R. W. and Casjens, S. (2006). Bacteriophage Lambda and its Genetic Neighborhood. In The Bacteriophages, $2^{\text {nd }}$ edition (eds. R. Calendar and S. T. B. Abedon), pp. 409-447. New York: Oxford University Press.

Hendrix, R. W., Smith, M. C. M., Burns, R. N., Ford, M. E. and Hatfull, G. F. (1999). Evolutionary relationships among diverse bacteriophages and prophages: All the world's a phage. Proceedings of the National Academy of Sciences of the United States of America 96, 2192-2197.

Hennes, K. P. and Simon, M. (1995). Significance of bacteriophages for controlling bacterioplankton growth in a mesotrophic lake. Applied and Environmental Microbiology 61, 333-340.

Herdianita, N. R., Browne, P. R. L., Rodgers, K. A. and Campbell, K. A. (2000). Mineralogical and textural changes accompanying ageing of silica sinter. Mineralium Deposita 35, 48-62.

Hesse, R. (1989). Silica diagenesis: origin of inorganic and replacement cherts. Earth-Science Reviews 26, 253-284.

Hidalgo, A. F. and Orr, C. (1968). Homogeneous nucleation of sodium chloride solutions. Industrial \& Engineering Chemistry Fundamentals 7, 79-83.

Hodoroaba, V. D., Motzkus, C., Mace, T. and Vaslin-Reimann, S. (2014). Performance of High-Resolution SEM/EDX Systems Equipped with Transmission Mode (TSEM) for Imaging and Measurement of Size and Size Distribution of Spherical Nanoparticles. Microscopy and Microanalysis 20, 602-612.

Holmes, E. C. (2003). Molecular clocks and the puzzle of RNA virus origins. Journal of Virology 77, 3893-3897. 
Icopini, G. A., Brantley, S. L. and Heaney, P. J. (2005). Kinetics of silica oligomerization and nanocolloid formation as a function of $\mathrm{pH}$ and ionic strength at 25 degrees C. Geochimica et Cosmochimica Acta 69, 293-303.

Iler, J. H. (1979a). Polymerization of Silica. In The Chemistry of Silica, pp. 172 311. New York: John Wiley and Sons, Inc.

Iler, R. H. (1979b). The Occurance, Dissolution and Deposition of Silica. In The Chemistry of Silica, pp. 3 - 115. New York: John Wiley and Sons, Inc.

Jain, N. K. and Roy, I. (2009). Effect of trehalose on protein structure. Protein Science 18, 24-36.

Janik, C. J. and McLaren, M. K. (2010). Seismicity and fluid geochemistry at Lassen Volcanic National Park, California: Evidence for two circulation cells in the hydrothermal system. Journal of Volcanology and Geothermal Research 189, 257-277.

Jardillier, L., Bettarel, Y., Richardot, M., Bardot, C., Amblard, C., SimeNgando, T. and Debroas, D. (2005). Effects of viruses and predators on prokaryotic community composition. Microbial Ecology 50, 557-569.

Jefferson, T. (1999). Vaccines make best use of available resources? (in other words are they cost-effective?). Vaccine 17, S69-S73.

Jiang, S. C. and Paul, J. H. (1998). Gene transfer by transduction in the marine environment. Applied and Environmental Microbiology 64, 2780-2787.

Jones, B., Konhauser, K. O., Renaut, R. W. and Wheeler, R. S. (2004a). Microbial silicification in Iodine Pool, Waimangu geothermal area, North Island, New Zealand: implications for recognition and identification of ancient silicified microbes. Journal of the Geological Society 161, 983-993. 
Jones, B. and Renaut, R. W. (2004). Water content of Opal-A: Implications for the origin of laminae in geyserite and sinter. Journal of Sedimentary Research 74, 117128.

Jones, B. and Renaut, R. W. (2007). Microstructural changes accompanying the opal-A to opal-CT transition: new evidence from the siliceous sinters of Geysir, Haukadalur, Iceland. Sedimentology 54, 921-948.

Jones, B., Renaut, R. W. and Rosen, M. R. (2000). Stromatolites forming in acidic hot-spring waters, North Island, New Zealand. Palaios 15, 450-475.

Jones, B., Renaut, R. W. and Rosen, M. R. (2004b). Taxonomic fidelity of silicified filamentous microbes from hot-spring systems in the Taupo Volcanic Zone, North Island, New Zealand. Transactions of the Royal Society of Edinburgh - Earth Sciences $94,475-483$.

Jonsson, N., Gullberg, M. and Lindberg, A. M. (2009). Real-time polymerase chain reaction as a rapid and efficient alternative to estimation of picornavirus titers by tissue culture infectious dose $50 \%$ or plaque forming units. Microbiology and Immunology 53, 149-154.

Kahler, H. (1941). Determination of soluble silica in water: A photometric method. Industrial \& Engineering Chemistry Analytical Edition 13, 536-539.

Karam, J. D. (1994). Bacteriophage T4. Washington, D.C.: ASM Press. Kenzaka, T., Tani, K., Sakotani, A., Yamaguchi, N. and Nasu, M. (2007). High-frequency phage-mediated gene transfer among Escherichia coli cells, determined at the single-cell level. Applied and Environmental Microbiology 73, 3291-3299. 
Khlystov, A., Stanier, C. O., Takahama, S. and Pandis, S. N. (2005). Water content of ambient aerosol during the Pittsburgh air quality study. Journal of Geophysical Research-Atmospheres 110, 10.

Klein, C. W. (1995). Management of fluid injection in geothermal wells to avoid silica scaling at low levels of silica oversaturation. Geothermal Resources Council Transactions 19, 503-511.

Kline, R. L., Regnery, R. L., Armstrong, G. L. and Damon, I. K. (2005). Stability of diluted smallpox vaccine under simulated clinical conditions. Vaccine 23, 4944-4946.

Kobayashi, M., Juillerat, F., Galletto, P., Bowen, P. and Borkovec, M. (2005). Aggregation and charging of colloidal silica particles: Effect of particle size. Langmuir $21,5761-5769$.

Konhauser, K., Jones, B., Phoenix, V., Ferris, G. and Renaut, R. (2004). The microbial role in hot spring silicification. Ambio 33, 552-558.

Koonin, E. V. and Martin, W. (2005). On the origin of genomes and cells within inorganic compartments. Trends in Genetics 21, 647-654.

Koonin, E. V., Senkevich, T. G. and Dolja, V. V. (2006). The ancient Virus World and evolution of cells. Biology Direct 1.

Krushelnitsky, A., Gogolev, Y., Golbik, R., Dahlquist, F. and Reichert, D. (2006). Comparison of the internal dynamics of globular proteins in the microcrystalline and rehydrated lyophilized states. Biochimica et Biophysica Acta-Proteins and Proteomics 1764, 1639-1645. 
Kyle, J. E., Pedersen, K. and Ferris, F. G. (2008). Virus mineralization at low $\mathrm{pH}$ in the Rio Tinto, Spain. Geomicrobiology Journal 25, 338-345.

Laidler, J. R., Shugart, J. A., Cady, S. L., Bahjat, K. S. and Stedman, K. M. (2013). Reversible inactivation and desiccation tolerance of silicified viruses. Journal of Virology 87, 13927-13929.

Laidler, J. R. and Stedman, K. M. (2010). Virus Silicification under Simulated Hot Spring Conditions. Astrobiology 10, 569-576.

Langlet, J., Gaboriau, F. and Gantzer, C. (2007). Effects of pH on plaque forming unit counts and aggregation of MS2 bacteriophage. Journal of Applied Microbiology 103, 1632-1638.

Lauer, B. A., Reller, L. B. and Mirrett, S. (1981). Comparison of Acridine Orange and Gram stains for detection of microorganisms in cerebrospinal-fluid and other clinical specimens. Journal of Clinical Microbiology 14, 201-205

Laurinavicius, S., Bamford, D. H. and Somerharju, P. (2007). Transbilayer distribution of phospholipids in bacteriophage membranes. Biochimica et Biophysica Acta - Biomembranes 1768, 2568-2577.

Lee, M. H., Keams, J. L., Helzer, D. W., Leiser, O. P., Ochoa, M. A., Connon, S. A., Magnuson, T. S. and Watwood, M. E. (2007). Evaluation of viral and prokaryotic community dynamics in Alvord Desert hot springs, Oregon, USA. Aquatic Microbial Ecology 48, 19-26.

Leiman, P. G., Chipman, P. R., Kostyuchenko, V. A., Mesyanzhinov, V. V. and Rossmann, M. G. (2004). Three-dimensional rearrangement of proteins in the tail of bacteriophage T4 on infection of its host. Cell 118, 419-429. 


\section{Leiman, P. G., Kanamaru, S., Mesyanzhinov, V. V., Arisaka, F. and}

Rossmann, M. G. (2003). Structure and morphogenesis of bacteriophage T4. Cellular and Molecular Life Sciences 60, 2356-2370.

Levine, M. M. and Robins-Browne, R. (2009). Vaccines, global health and social equity. Immunology and Cell Biology 87, 274-278.

Leyva-Illades, J. F., Setlow, B., Sarker, M. R. and Setlow, P. (2007). Effect of a small, acid-soluble spore protein from Clostridium perfringens on the resistance properties of Bacillus subtilis spores. Journal of Bacteriology 189, 7927-7931.

Liang, M. K., Patwardhan, S. V., Danilovtseva, E. N., Annenkov, V. V. and Perry, C. C. (2009). Imidazole catalyzed silica synthesis: Progress toward understanding the role of histidine in (bio)silicification. Journal of Materials Research 24, 1700-1708.

Lowe, D. R. (1994). Abiological origin of described stromatolites older than 3.2 Ga. Geology 22, 387-390.

Lynne, B. Y. and Campbell, K. A. (2003). Diagenetic transformations (opal-A to quartz) of low- and mid-temperature microbial textures in siliceous hot-spring deposits, Taupo Volcanic Zone, New Zealand. Canadian Journal of Earth Sciences 40, 1679-1696.

Lynne, B. Y. and Campbell, K. A. (2004). Morphologic and mineralogic transitions from opal-A to opal-CT in low-temperature siliceous sinter diagenesis, Taupo Volcanic Zone, New Zealand. Journal of Sedimentary Research 74, 561-579.

Lynne, B. Y., Campbell, K. A., Moore, J. N. and Browne, P. R. L. (2005). Diagenesis of 1900-year-old siliceous sinter (opal-A to quartz) at Opal Mound, Roosevelt Hot Springs, Utah, U.S.A. Sedimentary Geology 179, 249-278. 
Ma, L. L., Mao, G. N., Liu, J., Yu, H., Gao, G. H. and Wang, Y. Y. (2013). Rapid quantification of bacteria and viruses in influent, settled water, activated sludge and effluent from a wastewater treatment plant using flow cytometry. Water Science and Technology 68, 1763-1769.

Magagnini, M., Corinaldesi, C., Monticelli, L. S., De Domenico, E. and Danovaro, R. (2007). Viral abundance and distribution in mesopelagic and bathypelagic waters of the Mediterranean Sea. Deep-Sea Research Part I - Oceanographic Research Papers 54, 1209-1220.

Malferrari, M., Nalepa, A., Venturoli, G., Francia, F., Lubitz, W., Mobius, K. and Savitsky, A. (2014). Structural and dynamical characteristics of trehalose and sucrose matrices at different hydration levels as probed by FTIR and high-field EPR. Physical Chemistry Chemical Physics 16, 9831-9848.

Maranger, R. and Bird, D. F. (1995). Viral abundance in aquatic systems - a comparison between marine and fresh-waters. Marine Ecology - Progress Series 121, 217-226.

Marusyk, R. and Sergeant, A. (1980). A simple method for dialysis of smallvolume samples. Analytical Biochemistry 105, 403-404.

\section{McCleskey, R. B., Ball, J. W., Nordstrom, D. K., Holloway, J. M. and Taylor,} H. E. (2004). Water-chemistry data for selected hot springs, geysers, and streams in Yellowstone National Park, Wyoming, 2001-2002. Boulder, Colorado: U.S. Geological Survey. 
McGregor, S. and Mayor, H. D. (1971). Biophysical and biochemical studies on rhinovirus and poliovirus. 2. Chemical and hydrodynamic analysis of the rhinovirion. Journal of Virology 7, 41-6.

McKenzie, E. J., Brown, K. L., Cady, S. L. and Campbell, K. A. (2001). Trace metal chemistry and silicification of microorganisms in geothermal sinter, Taupo Volcanic Zone, New Zealand. Geothermics 30, 483-502.

Mera, M. U. and Beveridge, T. J. (1993). Mechanism of silicate binding to the bacterial cell wall in Bacillus subtilis. Journal of Bacteriology 175, 1936-1945.

Mesquita, M. M. F., Stimson, J., Chae, G. T., Tufenkji, N., Ptacek, C. J., Blowes, D. W. and Emelko, M. B. (2010). Optimal preparation and purification of PRD1-like bacteriophages for use in environmental fate and transport studies. Water Research 44, 1114-1125.

Middelboe, M., Jorgensen, N. O. G. and Kroer, N. (1996). Effects of viruses on nutrient turnover and growth efficiency of noninfected marine bacterioplankton. Applied and Environmental Microbiology 62, 1991-1997.

Miller, E. S., Kutter, E., Mosig, G., Arisaka, F., Kunisawa, T. and Ruger, W. (2003). Bacteriophage T4 genome. Microbiology and Molecular Biology Reviews 67, 86156.

Moreau, J. W. and Sharp, T. G. (2004). A transmission electron microscopy study of silica and kerogen biosignatures in-1.9 Ga gunflint microfossils. Astrobiology 4 , 196-210.

Mosig, G., Gewin, J., Luder, A., Colowick, N. and Vo, D. (2001). Two recombination-dependent DNA replication pathways of bacteriophage T4, and their roles 126 
in mutagenesis and horizontal gene transfer. Proceedings of the National Academy of Sciences of the United States of America 98, 8306-8311.

Naik, R. R., Brott, L. L., Clarson, S. J. and Stone, M. O. (2002). Silicaprecipitating peptides isolated from a combinatorial phage display peptide library. Journal of Nanoscience and Nanotechnology 2, 95-100.

Nakano, H., Hiraoka, M., Sameshima, M., Kimura, T. and Momoyama, K. (1998). Inactivation of penaeid rod-shaped DNA virus (PRDV), the causative agent of penaeid acute viremia (PAV), by some chemical and physical treatments. Fish Pathology $33,65-71$.

Newman, F. K., Frey, S. E., P. Blevins, T., Yan, L. and Belshe, R. B. (2003). Stability of undiluted and diluted Vaccinia-virus vaccine, Dryvax. Journal of Infectious Diseases 187, 1319-1322.

Nielsen-Marsh, C. M., Stegemann, C., Hoffmann, R., Smith, T., Feeney, R., Toussaint, M., Harvati, K., Panagopoulou, E., Hublin, J. J. and Richards, M. P. (2009). Extraction and sequencing of human and Neanderthal mature enamel proteins using MALDI-TOF/TOF MS. Journal of Archaeological Science 36, 1758-1763.

Noonan, J. P., Coop, G., Kudaravalli, S., Smith, D., Krause, J., Alessi, J., Platt, D., Paabo, S., Pritchard, J. K. and Rubin, E. M. (2006). Sequencing and analysis of Neanderthal genomic DNA. Science 314, 1113-1118.

Orange, F., Chabin, A., Gorlas, A., Lucas-Staat, S., Geslin, C., Le Romancer, M., Prangishvili, D., Forterre, P. and Westall, F. (2011). Experimental fossilisation of viruses from extremophilic Archaea. Biogeosciences 8, 1465-1475. 


\section{Orange, F., Westall, F., Disnar, J. R., Prieur, D., Bienvenu, N., Leromancer,}

M. and Defarge, C. (2009). Experimental silicification of the extremophilic Archaea Pyrococcus abyssi and Methanocaldococcus jannaschii: applications in the search for evidence of life in early Earth and extraterrestrial rocks. Geobiology 7, 403-418.

Ortmann, A. C. and Suttle, C. A. (2005). High abundances of viruses in a deepsea hydrothermal vent system indicates viral mediated microbial mortality. Deep-Sea Research Part I - Oceanographic Research Papers 52, 1515-1527.

Palm, P., Schleper, C., Grampp, B., Yeats, S., McWilliam, P., Reiter, W. D. and Zillig, W. (1991). Complete nucleotide sequence of the virus SSV1 of the archaebacterium Sulfolobus shibatae. Virology 185, 242-250.

\section{Patwardhan, S. V., Maheshwari, R., Mukherjee, N., Kiick, K. L. and}

Clarson, S. J. (2006). Conformation and assembly of polypeptide scaffolds in templating the synthesis of silica: An example of a polylysine macromolecular "switch". Biomacromolecules 7, 491-497.

Peduzzi, P. and Schiemer, F. (2004). Bacteria and viruses in the water column of tropical freshwater reservoirs. Environmental Microbiology 6, 707-715.

Peng, X., Xu, H., Jones, B., Chen, S. and Zhou, H. (2013). Silicified virus-like nanoparticles in an extreme thermal environment: implications for the preservation of viruses in the geological record. Geobiology 11, 511-526.

Peng, X. T., Zhou, H. Y., Wu, Z. J., Jiang, L., Tang, S., Yao, H. Q. and Chen, G. Q. (2007). Biomineralization of phototrophic microbes in silica-enriched hot springs in South China. Chinese Science Bulletin 52, 367-379. 
Personnic, S., Domaizon, I., Dorigo, U., Berdjeb, L. and Jacquet, S. (2009). Seasonal and spatial variability of virio-, bacterio-, and picophytoplanktonic abundances in three peri-alpine lakes. Hydrobiologia 627, 99-116.

Peterson, A. T. (2008). Biogeography of diseases: a framework for analysis. Naturwissenschaften 95, 483-491.

Phoenix, V. R., Adams, D. G. and Konhauser, K. O. (2000). Cyanobacterial viability during hydrothermal biomineralisation. Chemical Geology 169, 329-338.

Poinar, G. and Poinar, R. (2005). Fossil evidence of insect pathogens. Journal of Invertebrate Pathology 89, 243-250.

Potts, M. (1994). Desiccation tolerance of prokaryotes. Microbiological Reviews $58,755-805$.

Prangishvili, D. (2013). The Wonderful World of Archaeal Viruses. In Annual Review of Microbiology, vol. 67 (ed. S. Gottesman), pp. 565-585. Palo Alto: Annual Reviews.

Prangishvili, D., Arnold, H. P., Gotz, D., Ziese, U., Holz, I., Kristjansson, J. K. and Zillig, W. (1999). A novel virus family, the Rudiviridae: Structure, virus-host interactions and genome variability of the Sulfolobus viruses SIRV1 and SIRV2. Genetics 152, 1387-1396.

Prestrelski, S. J., Tedeschi, N., Arakawa, T. and Carpenter, J. F. (1993). Dehydration-induced conformational transitions in proteins and their inhibition by stabilizers. Biophysical Journal 65, 661-671. 
Prospero, J. M., Blades, E., Mathison, G. and Naidu, R. (2005).

Interhemispheric transport of viable fungi and bacteria from Africa to the Caribbean with soil dust. Aerobiologia 21, 1-19.

Purohit, P. K., Inamdar, M. M., Grayson, P. D., Squires, T. M., Kondev, J. and Phillips, R. (2005). Forces during bacteriophage DNA packaging and ejection. Biophysical Journal 88, 851-866.

Rappuoli, R., Mandl, C. W., Black, S. and De Gregorio, E. (2011). Vaccines for the twenty-first century society. Nature Reviews Immunology 11, 865-872.

Rauf, M. A., Soliman, A. A. and Khattab, M. (2008). Solvent effect on the spectral properties of Neutral Red. Chemistry Central Journal 2, 8.

Redder, P., Peng, X., Brugger, K., Shah, S. A., Roesch, F., Greve, B., She, Q. X., Schleper, C., Forterre, P., Garrett, R. A. et al. (2009). Four newly isolated fuselloviruses from extreme geothermal environments reveal unusual morphologies and a possible interviral recombination mechanism. Environmental Microbiology 11, 28492862.

Renaut, R. W., Jones, B. and Tiercelin, J. J. (1998). Rapid in situ silicification of microbes at Loburu hot springs, Lake Bogoria, Kenya Rift Valley. Sedimentology 45, 1083-1103.

Resch, W., Hixson, K. K., Moore, R. J., Lipton, M. S. and Moss, B. (2007). Protein composition of the vaccinia virus mature virion. Virology 358, 233-247.

Reysenbach, A. L. and Cady, S. L. (2001). Microbiology of ancient and modern hydrothermal systems. Trends in Microbiology 9, 79-86. 
Rice, G., Stedman, K., Snyder, J., Wiedenheft, B., Willits, D., Brumfield, S., McDermott, T. and Young, M. J. (2001). Viruses from extreme thermal environments. Proceedings of the National Academy of Sciences of the United States of America 98, 13341-13345.

Rice, G., Tang, L., Stedman, K., Roberto, F., Spuhler, J., Gillitzer, E., Johnson, J. E., Douglas, T. and Young, M. (2004). The structure of a thermophilic archaeal virus shows a double-stranded DNA viral capsid type that spans all domains of life. Proceedings of the National Academy of Sciences of the United States of America $101,7716-7720$.

Riemann, L. and Middelboe, M. (2002). Viral lysis of marine bacterioplankton: Implications for organic matter cycling and bacterial clonal composition. Ophelia 56, 5768.

Rimola, A., Sodupe, M. and Ugliengo, P. (2009). Affinity Scale for the Interaction of Amino Acids with Silica Surfaces. Journal of Physical Chemistry C 113, $5741-5750$.

Ripp, S., Ogunseitan, O. A. and Miller, R. V. (1994). Transduction of a freshwater microbial community by a new Pseudomonas aeruginosa generalized transducing phage, Ut1. Molecular Ecology 3, 121-126.

Roos, N., Cyrklaff, M., Cudmore, S., Blasco, R., KrijnseLocker, J. and Griffiths, G. (1996). A novel immunogold cryoelectron microscopic approach to investigate the structure of the intracellular and extracellular forms of vaccinia virus. EMBO Journal 15, 2343-2355. 
Russell, L. M. and Ming, Y. (2002). Deliquescence of small particles. Journal of Chemical Physics 116, 311-321.

Setlow, P. (1995). Mechanisms for the prevention of damage to DNA in spores of Bacillus species. Annual Review of Microbiology 49, 29-54.

Shapira, A. and Kohn, A. (1974). Effects of freeze-drying on bacteriophage-T4. Cryobiology 11, 452-464.

Schleper, C., Kubo, K. and Zillig, W. (1992). The particle SSV1 from the extremely thermophilic Archaeon Sulfolobus is a virus - demonstration of infectivity and of transfection with viral DNA. Proceedings of the National Academy of Sciences of the United States of America 89, 7645-7649.

Schopf, J. W. (2006). Fossil evidence of Archaean life. Philosophical Transactions of the Royal Society B - Biological Sciences 361, 869-885.

Schopf, J. W. and Packer, B. M. (1987). Early Archean (3.3-billion to 3.5billion-year-old) microfossils from Warrawoona Group, Australia. Science 237, 70-73.

SchultzeLam, S., Ferris, F. G., Konhauser, K. O. and Wiese, R. G. (1995). In situ silicification of an Icelandic hot spring microbial mat: Implications for microfossil formation. Canadian Journal of Earth Sciences 32, 2021-2026.

Short, C. M. and Suttle, C. A. (2005). Nearly identical bacteriophage structural gene sequences are widely distributed in both marine and freshwater environments. Applied and Environmental Microbiology 71, 480-486.

Siering, P. L. and Ghiorse, W. C. (1997). Development and application of 16S rRNA-targeted probes for detection of iron- and manganese-oxidizing sheathed bacteria in environmental samples. Applied and Environmental Microbiology 63, 644-651. 
Singh, H., Anurag, K. and Apte, S. K. (2013). High radiation and desiccation tolerance of nitrogen-fixing cultures of the cyanobacterium Anabaena sp strain PCC 7120 emanates from genome/proteome repair capabilities. Photosynthesis Research 118, 7181.

Slovackova, H. and Marsalek, B. (2008). Virioplankton and microbial communities in two Czech rivers (Svratka and Morava River). Aquatic Sciences 70, 282291.

Smith, D. J., Griffin, D. W. and Schuerger, A. C. (2010). Stratospheric microbiology at $20 \mathrm{~km}$ over the Pacific Ocean. Aerobiologia 26, 35-46.

Smith, G. L., Vanderplasschen, A. and Law, M. (2002). The formation and function of extracellular enveloped Vaccinia virus. Journal of General Virology 83, 2915-2931.

Snyder, J. (2005). Virus dynamics, archaeal populations, and water chemistry of three acidic hot springs in Yellowstone National Park. (Doctoral Thesis, Montana State University).

\section{Snyder, J. C., Wiedenheft, B., Lavin, M., Roberto, F. F., Spuhler, J.,}

Ortmann, A. C., Douglas, T. and Young, M. (2007). Virus movement maintains local virus population diversity. Proceedings of the National Academy of Sciences of the United States of America 104, 19102-19107.

Stanley, W. M. and Anderson, T. F. (1941). A study of purified viruses with the electron microscope. Journal of Biological Chemistry 139, 325-338. 
Stedman, K. M. and Laidler, J. R. (2013). Immunogenic compositions comprising silicified virus and methods of use. US Provisional Patent Application No. 61/759,131. Portland, Oregon: U.S. Patent and Trademark Office

Stedman, K. M., Prangishvili, D. and Zillig, W. (2006). Viruses of Archaea. In The Bacteriophages, $2^{\text {nd }}$ edition (ed. R. Calendar and S.T.B Abedon), pp. 499-516. Oxford: Oxford University Press.

Stedman, K. M., She, Q. X., Phan, H., Arnold, H. P., Holz, I., Garrett, R. A. and Zillig, W. (2003). Relationships between fuselloviruses infecting the extremely thermophilic archaeon Sulfolobus: SSV1 and SSV2. Research in Microbiology 154, 295302.

Strong, C. and Davis, R. E. (2008). Variability in the position and strength of winter jet stream cores related to northern hemisphere teleconnections. Journal of Climate 21, 584-592.

Sullivan, M. B., Lindell, D., Lee, J. A., Thompson, L. R., Bielawski, J. P. and Chisholm, S. W. (2006). Prevalence and evolution of core photosystem II genes in marine cyanobacterial viruses and their hosts. PLoS Biology 4, 1344-1357.

Suttle, C. A. (2005). Viruses in the sea. Nature 437, 356-361.

Suttle, C. A. (2007). Marine viruses - major players in the global ecosystem. Nature Reviews Microbiology 5, 801-812.

Swanson, M. M., Fraser, G., Daniell, T. J., Torrance, L., Gregory, P. J. and Taliansky, M. (2009). Viruses in soils: morphological diversity and abundance in the rhizosphere. Annals of Applied Biology 155, 51-60. 
Taira, Y., Uchimiya, M. and Kudo, I. (2009). Simultaneous estimation of viral lysis and protozoan grazing on bacterial mortality using a modified virus-dilution method. Marine Ecology - Progress Series 379, 23-32.

Tanaka, M. and Takahashi, K. (2002). Characterization of silicate monomer with sodium, calcium and strontium but not with lithium and magnesium ions by fast atom bombardment mass spectrometry. Journal of Mass Spectrometry 37, 623-630.

Tansey, M. R. and Brock, T. D. (1972). Upper temperature limit for Eukaryotic organisms. Proceedings of the National Academy of Sciences of the United States of America 69, 2426-2428.

Theze, J., Bezier, A., Periquet, G., Drezen, J. M. and Herniou, E. A. (2011). Paleozoic origin of insect large dsDNA viruses. Proceedings of the National Academy of Sciences of the United States of America 108, 15931-15935.

Thiel, G., Moroni, A., Dunigan, D. and Van Etten, J. L. (2010). Initial events associated with virus PBCV-1 infection of Chlorella NC64A. In Progress in Botany 71, vol. 71 (eds. U. Luttge W. Beyschlag B. Budel and D. Francis), pp. 169-183. Berlin: Springer-Verlag Berlin.

Thingstad, T. F. (2000). Elements of a theory for the mechanisms controlling abundance, diversity, and biogeochemical role of lytic bacterial viruses in aquatic systems. Limnology and Oceanography 45, 1320-1328.

Thompson, J. M. (1985). Chemistry of thermal and nonthermal springs in the vicinity of Lassen Volcanic National Park. Journal of Volcanology and Geothermal Research 25, 81-104. 
Thompson, J. (1983). Chemical analysis of thermal and non-thermal springs in Lassen Volcanic National Park and vicinity, California. Open File Report 83-311, pp. 2023: USGS.

Tian, H. H., Wei, C. F., Wei, H. Z., Yan, R. T. and Chen, P. (2014). An NMRbased analysis of soil-water characteristics. Applied Magnetic Resonance 45, 49-61.

Tice, M. M. and Lowe, D. R. (2004). Photosynthetic microbial mats in the 3,416-Myr-old ocean. Nature 431, 549-552.

Toporski, J. K. W., Steele, A., Westall, F., Thomas-Keprta, K. L. and McKay, D. S. (2002). The simulated silicification of bacteria - New clues to the modes and timing of bacterial preservation and implications for the search for extraterrestrial microfossils. Astrobiology 2, 1-26.

Van Etten, J. L., Burbank, D. E., Kuczmarski, D. and Meints, R. H. (1983). Virus-infection of culturable Chlorella-like algae and development of a plaque-assay. Science 219, 994-996.

Veit, M., Reverey, H. and Schmidt, M. F. (1996). Cytoplasmic tail length influences fatty acid selection for acylation of viral glycoproteins. Biochemical Journal 318, 163-172.

Verma, M. P. (2000). Chemical thermodynamics of silica: a critique on its geothermometer. Geothermics 29, 323-346.

Walcott, C. D. (1915). Discovery of Algonkian bacteria. Proceedings of the National Academy of Sciences of the United States of America 1, 256-257. 
Wallace, A. F., DeYoreo, J. J. and Dove, P. M. (2009). Kinetics of silica nucleation on carboxyl- and amine-terminated surfaces: Insights for biomineralization. Journal of the American Chemical Society 131, 5244-5250.

Walsh, R. L. and Camilli, A. (2011). Streptococcus pneumoniae is desiccation tolerant and infectious upon rehydration. mBio 2, 6. DOI: 10.1128/mBio.00092-11

Wei, J., Saxena, A., Song, B., Ward, B. B., Beveridge, T. J. and Myneni, S. C. B. (2004). Elucidation of functional groups on gram-positive and gram-negative bacterial surfaces using infrared spectroscopy. Langmuir 20, 11433-11442.

Weinbauer, M. G. (2004). Ecology of prokaryotic viruses. FEMS Microbiology Reviews 28, 127-181.

Wen, K., Ortmann, A. C. and Suttle, C. A. (2004). Accurate estimation of viral abundance by epifluorescence microscopy. Applied and Environmental Microbiology 70, $3862-3867$.

Weres, O., Yee, A. and Tsao, L. (1981). Kinetics of silica polymerization. Journal of Colloid and Interface Science 84, 379-402.

Westall, F., Boni, L. and Guerzoni, E. (1995). The experimental silicification of microorganisms. Palaeontology 38, 495-528.

White, D. E., Brannock, W. W. and Murata, K. J. (1956). Silica in hot-spring waters. Geochimica et Cosmochimica Acta 10, 27-59.

Wiedenheft, B., Stedman, K., Roberto, F., Willits, D., Gleske, A. K., Zoeller, L., Snyder, J., Douglas, T. and Young, M. (2004). Comparative genomic analysis of hyperthermophilic archaeal Fuselloviridae viruses. Journal of Virology 78, 1954-1961. 
Wilhelm, S. W. and Suttle, C. A. (1999). Viruses and nutrient cycles in the sea viruses play critical roles in the structure and function of aquatic food webs. Bioscience 49, 781-788.

Wilson, C. L., Hinman, N. W., Cooper, W. J. and Brown, C. F. (2000). Hydrogen peroxide cycling in surface geothermal waters of Yellowstone National Park. Environmental Science and Technology 34, 2655-2662.

Wommack, K. E. and Colwell, R. R. (2000). Virioplankton: Viruses in aquatic ecosystems. Microbiology and Molecular Biology Reviews 64, 69-114.

Wood, J. P., Choi, Y. W., Wendling, M. Q., Rogers, J. V. and Chappie, D. J. (2013). Environmental persistence of vaccinia virus on materials. Letters in Applied Microbiology 57, 399-404.

Yee, N., Phoenix, V. R., Konhauser, K. O., Benning, L. G. and Ferris, F. G. (2003). The effect of cyanobacteria on silica precipitation at neutral $\mathrm{pH}$ : implications for bacterial silicification in geothermal hot springs. Chemical Geology 199, 83-90.

Yokoyama, T., Taguchi, S., Motomura, Y., Watanabe, K., Nakanishi, T., Aramaki, Y. and Izawa, E. (2004). The effect of aluminum on the biodeposition of silica in hot spring water: Chemical state of aluminum in siliceous deposits collected along the hot spring water stream of Steep Cone hot spring in Yellowstone National Park, USA. Chemical Geology 212, 329-337.

Zaksek, K., Hort, M., Zaletelj, J. and Langmann, B. (2013). Monitoring volcanic ash cloud top height through simultaneous retrieval of optical data from polar orbiting and geostationary satellites. Atmospheric Chemistry and Physics 13, 2589-2606. 
Zerulla, K. and Soppa, J. (2014). Polyploidy in haloarchaea: advantages for growth and survival. Frontiers in Microbiology 5, 8.

\section{Zhang, X. Z., Xiang, Y., Dunigan, D. D., Klose, T., Chipman, P. R., Van}

Etten, J. L. and Rossmann, M. G. (2011). Three-dimensional structure and function of the Paramecium bursaria chlorella virus capsid. Proceedings of the National Academy of Sciences of the United States of America 108, 14837-14842.

\section{Zillig, W., Prangishvilli, D., Schleper, C., Elferink, M., Holz, I., Albers, S.,}

Janekovic, D. and Gotz, D. (1996). Viruses, plasmids and other genetic elements of thermophilic and hyperthermophilic Archaea. FEMS Microbiology Reviews 18, 225-236. 